\title{
De nuevo sobre la ejecutoria de don Francisco Pizarro: la llegada de remesas de oro americano a España (1536-1553)
}

\section{Again on the enforceable chart of don Francisco Pizarro: the arrival of American gold stocks to Spain (1536-1553)}

\author{
Pedro Andrés PORRAS ARBOLEDAS \\ Catedrático acreditado de Historia del Derecho \\ Departamento de Historia del Derecho \\ Instituto de Metodología e Historia de la Ciencia Jurídica \\ Facultad de Derecho. UCM \\ pporras@der.ucm.es
}

Recibido: 8 de enero de 2016

Aceptado: 15 de marzo de 2016

\section{RESUMEN}

Además de relacionar el fin último de la ejecutoria de un proceso entre don Francisco Pizarro, gobernador del Perú, y su mandatario, Pedro de Barrantes, ya editada previamente, por el oro enviado a España, en este trabajo se pasa revista a los demás datos extraídos del archivo de la Chancillería granadina referentes a la llegada de metales preciosos a la Península, sin olvidar un curioso proceso de un súbdito del Preste Juan.

PAlABRAS ClaVE: don Francisco Pizarro, Gonzalo Pizarro, Hernando Pizarro, Perú, remesas de oro, Tierra del Preste Juan de las Indias.

\begin{abstract}
Besides researching the last goal of the execution of a trial between Francisco Pizarro, governor of Peru, and his mandatory, Pedro de Barrantes on behalf of the gold sent to Spain, the present work reviews all the data found in the Archives of the Grenade Chancellery on the arrival of gold to Spain. Also, a curious trial on a subject of Preste Juan is included.
\end{abstract}

KEYWORDS: Francisco Pizarro, Gonzalo Pizarro, Hernando Pizarro, Peru, gold stocks, Land of Preste Juan de las Indias

\section{RÉSUMÉ}

En plus de relier le but ultime de l'exécution d'un processus entre don Francisco Pizarro, gouverneur du Pérou, et son mandataire, Pedro de Barrantes sur l'or envoyé à l'Espagne, ce travail enquête sur d'autres données extraits de l'Archive de la Chancellerie de Grenade concernant l'arrivée des métaux précieux en Espagne, aussi qu'un curieux processus concernant un sujet du Preste Juan.

MOTS CLÉ: Don Francisco Pizarro, Gonzalo Pizarro, Hernando Pizarro, Pérou, envois de fonds d'or, Terre du Preste Juan des Indes. 
SUMARIO: 1. Ejecutoria entre don Francisco Pizarro y Pedro de Barrantes. Fase ejecutiva. 2. Otros documentos americanos de la Chancillería de Granada. 2.1. Procesos de Barrantes, Pizarro y Chaves. 2.2. Geografía hispano-americana. 2.3. Los procesos por el oro. 2.4. Procesos por bienes hispanoamericanos. 2.5. Procesos por la liberación de esclavos indios. 2.6. Proceso por la liberación del súbdito del Preste Juan. 3. Conclusiones. Apéndice I. Apéndide II.

\section{Ejecutoria entre don Francisco Pizarro y Pedro de Barrantes. Fase ejecutiva}

Publiqué en las páginas de estos mismos Cuadernos, tres años atrás, un trabajo en el que recogía la ejecutoria de la Chancillería granadina ganada por el conquistador del Perú a Pedro de Barrantes, que había transportado el oro de Pizarro desde aquellas remotas tierras a la península. ${ }^{1} \mathrm{~A}$ pesar de haber acabado aquel proceso en ejecutoria, lo cierto es que Barrantes se las ingenió para reconducir el caso en la fase ejecutiva. Recordemos lo sucedido durante la primera parte del proceso, para, acto seguido, enlazar con la nueva ejecutoria, ganada en cierto modo por Barrantes.

Según la demanda presentada por la parte de Pizarro, su hermano Juan había entregado en Jauja a Barrantes, también vecino de Trujillo, 10.000 pesos de oro, valorados a $450 \mathrm{mrs} . /$ peso - si bien en otro momento se explica que se trataba de 15.000 pesos de 15 quilates en 52 barras y una plancha de oro-; sea como fuere, llegado el oro a la Casa de Contratación sevillana, se valoró todo ello en 5.362.343 mrs. La Corona se quedó con 4.511.250 mrs., esto es, el 84\% del valor del oro importado a nombre de Pizarro, equivalente a la cinco sextas partes del total, alegando que ya se había hecho así en ocasiones anteriores. ${ }^{2}$ Así pues, restaban para el gobernador sólo 851.093 mrs. Aunque no se explica con claridad en el documento, parece que en Sevilla quedó todo el metal, sin que se abonase cantidad alguna en metálico al transportista ${ }^{3}$ más parece que la Corona colocó en juros

\footnotetext{
${ }^{1}$ «Documentos granadinos: Las corruptelas del doctor Quirós (1521) y la ejecutoria ganada por don Francisco Pizarro, gobernador del Perú, ante la Chancillería de Granada (1538)», Cuadernos de Historia del Derecho, XX, 2013, pp. 411-433. La continuación de mis pesquisas en los fondos de la Audiencia granadina me ha deparado el hallazgo de esta nueva ejecutoria, catorce años posterior (Archivo de la Real Chancillería de Granada, expte. 5.786. Transcrita en apéndice I).

Como decía en mi trabajo anterior, tan sólo pretendo dar a conocer los documentos con que me he ido encontrando en mis investigaciones, sin deseo alguno de introducirme en corral ajeno. Que nadie espere una sesuda nota bibliográfica, pues sólo se exponen los datos de la forma más ordenada posible, con algunas consideraciones personales, que poco vienen a alterar cosas sabidas, sin embargo, creo que, como decía medio siglo atrás Konetzke, la bibliografía sobre temas americanistas es enorme, a pesar de lo cual es enorme también lo que queda por saber.

${ }^{2}$ Sobre los secuestros de oro y plata de particulares por parte de la Corona en estos años Carretero opina que están poco estudiados, a pesar de su importancia y continuidad (Juan M. Carretero Zamora, Gobernar es gastar. Carlos V, el servicio de las Cortes de Castilla y la deuda de la Monarquía Hispánica, 1516-1556, Madrid, 2016, pp. 382-384).

${ }^{3}$ Cabe también la posibilidad que la Casa de Contratación abonase a Barrantes dichos 529.500 mrs., que éste cedería a la hermana de Pizarro, pagándole en juros los restantes 321.199 mrs. Esta
} 
el dinero debido a Pizarro, cuyos títulos debieron de ser entregados a su hermana, Inés Rodríguez de Aguilar. ${ }^{4}$ Es el caso que Barrantes abonó en metálico a la parte de su mandante un total de 529.500 mrs., dejando pendientes los restantes 321.199 mrs. — todo ello según las cuentas rendidas en el proceso-. Pretendía Barrantes pagar a la familia de Pizarro 264.937 mrs. y quedarse los 56.250 restantes en calidad de derechos de portes.

Por desgracia, la primera ejecutoria no aclara los muchos dimes y diretes que se produjeron durante el proceso, tan sólo nos dice que en la sentencia de vista de la Audiencia granadina se condenó a Barrantes a pagar a Pizarro 265.187 mrs., atribuyendo a aquél por derechos de transporte un total de $56.000 \mathrm{mrs}$., para lo cual la parte del gobernador del Perú debía hacer entrega a la de Barrantes de los juros situados por el monarca a favor de aquél o una certificación de los mismos, junto con los corridos de dichos juros. La sentencia de revista, que resultó ser la definitiva, confirmó la anterior, pero dispuso que sólo se pagasen de portes 10.000 mrs., debiendo abonar, por tanto, Barrantes a Pizarro los 311.997 mrs. restantes, aunque sin mencionar expresamente que éste debía hacer entrega a aquél de los juros o su certificación, en su defecto (11/04/1538).

Acto seguido, dos semanas más tarde, se inicia el relato de la segunda ejecutoria, cuando la parte de Francisco Pizarro acudió ante la justicia de Trujillo a pedir la ejecución de la primera ejecutoria; lógicamente, Barrantes contestó que, antes de nada, se le hiciese entrega de la certificación del juro por el que iba a ser ejecutado.

Hay, sin embargo, que comenzar diciendo que, dado que Francisco Pizarro (1478-1541) falleció durante la celebración del segundo proceso (1538-1552), el litigio acabó moviéndose entre Pedro de Barrantes, que para 1545 ya había conseguido situarse dentro del cabildo de los regidores trujillanos, ${ }^{5}$ y los familiares del difunto: eran éstos Fernando Pizarro e Inés Rodríguez de Aguilar, vecinos de Trujillo, y Francisca Rodríguez, moradora en La Zarza, lugar de su término, ${ }^{6}$ hijos de Gonzalo Pizarro y hermanos, por tanto, de los difuntos don Francisco, Juan y Gonzalo Pizarro. ${ }^{7}$

parece la conclusión más plausible, toda vez que en la sentencia definitiva del segundo proceso se dice que los Pizarro debían entregar a Barrantes el privilegio de juro por valor de $311.997 \mathrm{mrs}$. Los $9.202 \mathrm{mrs}$. de diferencia deben de corresponder al premio de $10.000 \mathrm{mrs}$. concedido al transportista.

${ }_{5}^{4}$ En el segundo proceso esta Inés parece que es llamada también, momentáneamente, Leonor.

${ }^{5}$ Es de suponer que exista una relación entre el desenlace final del proceso y el ascenso social de Barrantes, puesto que la cobranza durante años de los réditos de esos juros debió de superar con mucho el pago de los $10.000 \mathrm{mrs}$. que le habían correspondido como transportista, si bien es cierto que hubo de adelantar a los Pizarro el principal de los mismos. Algún oro traería para sí Barrantes también.

${ }^{6}$ El lugar sería adquirido en 1627 por Juan Hernando Pizarro, primer marqués de la Conquista y nieto del conquistador, sobre el que constituiría señorío (Luis Vicente Pelegrí Pedrosa, «La compra de la Zarza por Juan Hernando Pizarro», http://www.chdetrujillo.com/la-compra-de-la-zarza-porjuan-hernando-pizarro).

${ }^{7}$ Juan Pizarro viviría entre los años 1500 y 1536; Gonzalo Pizarro entre 1510 y 1548, en tanto que Hernando/Fernando Pizarro, que desde 1535 se nominaba caballero de la Orden de Santiago, nació en 1504 y falleció en 1580, luego de haber estado preso 20 años en el castillo de la Mota de 
Asentada la cantidad que Barrantes debía satisfacer y la que le correspondía por el transporte, lo que se debatía durante la ejecución de la sentencia no era otra cosa que la entrega por los Pizarro y Rodríguez de Aguilar de los títulos de los juros; de otro modo, Barrantes quedaría burlado, pues, además de pagar en metálico la deuda, no tendría derecho a resarcirse de lo que le correspondía. Dicho de otro modo, los Pizarro cobrarían dos veces, en metálico y en juros.

Ante la reclamación de Barrantes, Inés/Leonor intentó escabullirse diciendo que la certificación ya obraba en poder de la parte contraria, por lo que el teniente de corregidor de Trujillo dio mandamiento ejecutorio, dictándose la correspondiente sentencia de trance y remate, a pesar de haber interpuesto Barrantes apelación de dicho mandamiento. Acto seguido, se produjo una primera y única ejecución sobre un majuelo que Barrantes tenía en la Sierra del Erguijuelo, siendo rematado en un testaferro en 10.000 mrs., que lo cedió a los Pizarro. Así mismo, Barrantes hubo de abonar las costas del proceso. En opinión, pues, del teniente de corregidor se probaba que Barrantes había recibido ya su certificación - Francisco de Zabala, factor de Francisco Pizarro, había hecho entrega de dicha documentación a Rodrigo de Hermosilla, procurador de Barrantes- y no le quedaba otra que pagar la deuda.

Sintiéndose agraviado, el ejecutado volvió a apelar ante la Chancillería de Granada, si bien, de momento - para evitar la continuación de las ejecuciones y las molestias a sus fiadores - decidió abonar la deuda con la entrega de 732 ducados, 1.100 reales y $97 \mathrm{mrs}$. Inés se dio por contenta y pagada, en nombre de su hermano. Así pues, Barrantes había pagado el principal y costas, más los derechos de la ejecución al alguacil de la ciudad, que alcanzaron los 40 ducados.

Continuó el proceso ante los oidores de la Audiencia granadina, sin que los Pizarro se molestasen en personarse en la causa. En la argumentación de su apelación Barrantes volvía a reclamar la entrega del privilegio del juro. Entre tanto, se había alcanzado el año 1541, fecha en que don Francisco fue asesinado cobardemente en Lima, por lo que hubo de librarse citatoria para que sus herederos se constituyesen ante la Chancillería para que Barrantes litigase con ellos. Fueron notificados Inés y Francisca Rodríguez, en la Zarza y Hernando Pizarro, en la fortaleza de la Mota. Dicha notificación al preso no dejó de presentar sus dificultades, ya que, por orden real expresa, estaba aislado del exterior, lo que volvería a ocurrir en dos sucesivas comunicaciones. A la altura de 1545 Barrantes volvió a pedir traslado de lo procesado en Trujillo para impulsar de nuevo el pleito. ${ }^{8}$

Medina del Campo (1541-1561), por el asesinato de Diego de Almagro; así, en este proceso se intentará en varias ocasiones notificar a Hernando diversos emplazamientos, estando preso en dicha fortaleza.

${ }^{8}$ 1545/02/28. Granada. Compulsoria por apelación a Flor de Santa Cruz y García de Sanabria, escribanos públicos de Trujillo, a petición de Alonso Moyano, procurador de Pedro de Barrantes, regidor de la ciudad, que expuso cómo trataba pleito ante la Chancillería con los causahabientes del gobernador don Francisco Pizarro, en que se había hecho ejecución en sus bienes por valor de 300.000 mrs. y pico, sin que Pizarro le hubiera hecho entrega del juro o certificado del mismo, como 
En ausencia de los Pizarro fue dictada sentencia de vista por los oidores, que confirmaron en todos sus términos la del teniente de corregidor trujillano $(10 / 12 / 1547)$.

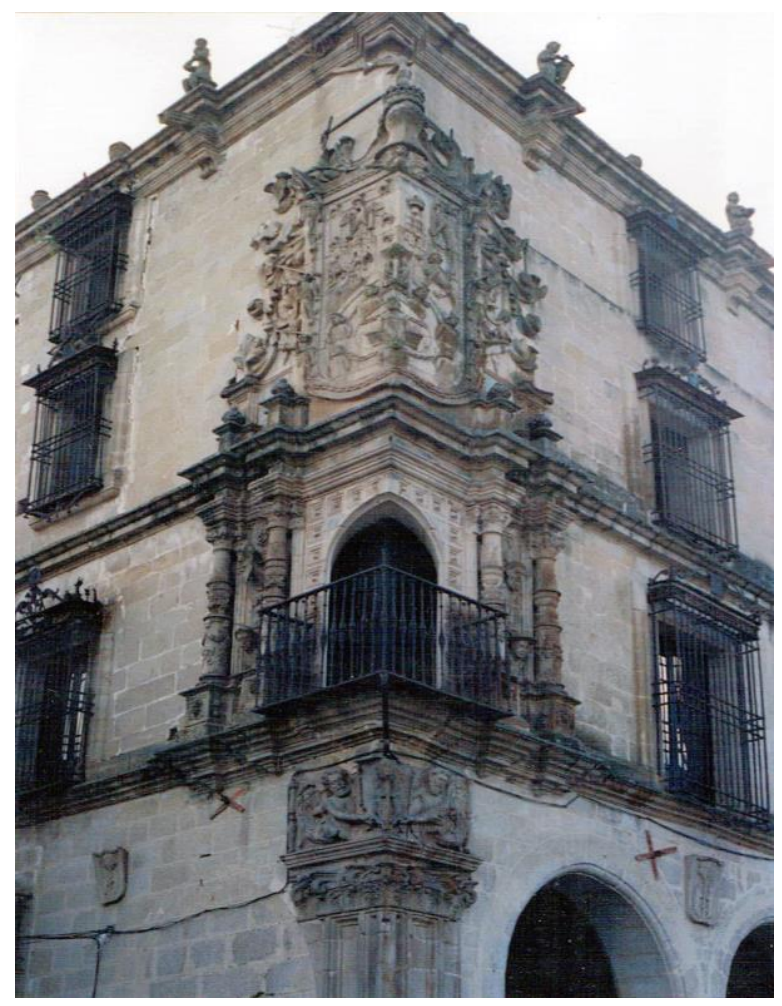

Palacio del marqués de la Conquista (Trujillo)

Insatisfecho con lo fallado, Barrantes volvió a insistir en su nueva apelación en que no se había exhibido el título o la certificación del mismo, que él precisaba para cobrar los réditos del juro. Para fundamentar el incumplimiento de lo dispuesto en la sentencia de vista del anterior proceso, hizo ver las contradicciones existentes en la documentación presentada en el mismo, que desembocaban en la incongruencia de fechas y actos. Esta vez parece que la argumentación de su escrito fue de una lógica que los oidores no pudieron evitar reconocer. A instancias del ejecutado, se volvió a emplazar a los hermanos Inés y Francisca Rodríguez y Hernando Pizarro, pues continuaban en rebeldía.

De este modo el proceso seguía languideciendo, hasta que a fines de enero de 1549 Barrantes compareció para expresar el fallecimiento de Gonzalo Pizarro,

estaba obligado, ejecución de la que había apelado. Ahora quería seguir con el proceso, del cual pedía se le diese traslado, no obstante se le hubiese dado anteriormente. Dr. Miguel de Ribera. Lcdos. Tello Girón y Melchor de León. Secretario, Adarve (ARChG, expte. 5.693). 
dejando por heredero de sus bienes y de los de su hermano Juan a Hernando Pizarro, que seguía preso en Medina del Campo. De nuevo fue intentado notificar el reo, sin mayor éxito, pues el receptor de la comunicación fue nuevamente el alcaide de la Mota. Finalmente, antes de que se dictase la sentencia de revista, la definitiva, la parte de Barrantes presentó nuevas probanzas y la de Hernando realizó ciertas posiciones. ${ }^{9}$

En la sentencia de revista los oidores confirmaron parcialmente la anterior y, por ende, la de primera instancia, sin embargo, revocaron el pago de las costas de la ejecución y de la instancia, condenando a la parte de los Pizarro a la entrega en plazo de 30 días del privilegio del juro de los 311.997 mrs. o la certificación correspondiente de la Casa de Contratación de Sevilla, así como al pago de los corridos desde el momento en que Barrantes había abonado esa deuda a sus acreedores en efectivo, siendo apercibida de que, de lo contrario, debería restituírselos en metálico (23/08/1552). La fecha de libramiento de la carta ejecutoria llevaba los datos de día y mes en blanco.

\section{Otros documentos americanos de la Chancillería de Granada 2.1. Procesos de Barrantes, Pizarro y Chaves}

Entre los documentos referentes a América que se conservan por esos años en el Registro del Sello de la Chancillería de Granada volvemos a encontrar tanto a Pedro de Barrantes como a distintos Pizarro de la familia del conquistador, si bien hay que decir que el apellido era relativamente corriente en Trujillo y resulta difícil establecer el parentesco con don Francisco; en cualquier caso, tratándose de otras personas, radicadas en tierras extremeñas, y de temas de interés local, no merece la pena detenerse aquí en las mismas; tan sólo dejar constancia de la existencia de esos documentos para posibles interesados.

A Pedro de Barrantes le encontramos en julio de 1540 apelando de una sentencia del teniente de corregidor de Trujillo, favorable a su convecino García Ramiro, sobre razón de ciertas demandas de penas de ganados; nada que ver, pues, con América. ${ }^{10}$

Hemos visto cómo Hernando Pizarro estuvo preso 20 años en Medina del Campo por lo sucedido en Perú durante la época de hegemonía de su familia; aunque falleció antes, el papel de su hermano Gonzalo también fue cuestionado lógicamente; de esto contamos con una curiosa referencia de 1552. Al parecer, el

\footnotetext{
${ }^{9}$ No sabemos si se refiere a que juró de calumnia y respondió a las posiciones puestas por Barrantes o a que también presentó probanzas; en cualquier caso, según se dice en la sentencia, Hernando seguía en rebeldía en el proceso, lo que es contradictorio.

${ }^{10}$ 1540/07/13. Granada. Citatoria y compulsoria a García Ramiro, vecino de Trujillo, a petición de Pedro Barrantes, también vecino, que apelaba de auto del teniente de corregidor de la ciudad. Emplazado en 15 días y compulsa en 4. Dr. Ribera. Lcdos. Ramírez de Alarcón y Montalvo. Escribano, Barahona (ARChG, expte. 5.650). De este personaje se conservan otros documentos en el Registro del Sello, que no he extraído, sobre asuntos variados.
} 
Lcdo. Ágreda, fiscal del Consejo de Indias, había denunciado ante el vicario de la villa de Madrid a Diego Martín clérigo, vecino de Trujillo y estante en la villa, por haber pronunciado unas palabras en defensa del difunto Gonzalo Pizarro, provocando un conflicto de competencias. ${ }^{11}$

El mismo comendador Hernando Pizarro, junto con su hermana Inés, anduvo pleiteando por los años 1538-1539 con Diego de Vargas Carvajal y su mujer, doña Beatriz de Vargas, vecinos de Trujillo, por unas casas y por la dehesa de María Alonso. ${ }^{12}$ Este Diego sería señor del Puerto de Santa Cruz, además de co-

11 1552/01/15. Granada. Inhibitoria al oficial y vicario de la villa de Madrid y al Lcdo. Cervantes, provisor de la ciudad de Sevilla: ante los oidores había comparecido Antón Hernández, procurador de Diego Martín clérigo, vecino de la ciudad de Trujillo, estante en la de Sevilla, y se querelló de aquéllos, diziendo que vos, el dicho vicario, por denunciación e querella que ante vos avía fecho el licenciado Ágreda, fiscal de nuestro Consejo de las Yndias, diziendo aver dicho ciertas palabras en fabor de Gonzalo Piçarro difunto, avíades dado vuestra requysitoria para que vos, el dicho provisor, prendiésedes a su parte e lo enbiásedes preso a la dicha villa de Madrid ante vos, el dicho vicario, e que por virtud de la dicha requysitoria, sin costar por ella que su parte oviese dicho las dichas palabras ny que oviese fecho ny cometido delito por que deviese ser preso, lo prendistes e tenyades preso en la cárcel arçobispal de la dicha cibdad, e porque sobre lo mesmo qu'el dicho fiscal se avía quexado de su parte e otras cosas que se le oponyan que avía fecho y dicho en favor del dicho Gonçalo Piçarro, su parte avía tratado pleito con el dicho fiscal ante fray Francisco de Morales, prior de Sant Juan de Acre, juez delegado de Su Santidad, su parte avía parecido ante vos, el dicho provisor y ant'el dicho vicario de Madrid y declinado jurisdición y os avía pedido y requerido no os entremetiésedes a conocer de la dicha causa e la remitiésedes al dicho prior, como juez conpetente, e no lo avíades hecho, antes avíades hecho prender al dicho su parte, e lo avíades mandado remytir a la dicha villa de Madrid, a pesar de que el juez delegado le había ordenado lo contrario, etc. por lo que ahora había apelado por vía de fuerza.

Orden de conceder la apelación presentada, si había lugar en derecho, y de reponer la causa al estado en que estaba en el momento de ser apelada; orden de remitir la causa original en 15 días con el escribano de la misma; orden de levantar la excomunión a todos los implicados y de enviar procurador bien instruido. Lcdos. Castilla, Oviedo y Frías. Secretario, Barahona (ARChG, expte. 5.768).

12 1538/04/06. Granada. Receptoria a las justicias de Trujillo y demás del Reino, para realizar ante dos escribanos, a petición del comendador Hernando Pizarro, vecino de la ciudad. Litigaban ante los oidores Diego de Vargas Carvajal y el comendador Hernando Pizarro, vecinos de Trujillo, sobre razón de unas casas que el dicho Diego de Vargas pide y demanda; recibidos a prueba en plazo de 60 días, a contar desde el pasado 30 de marzo. Ramírez, Peralta y Ribera. Registrador, Juan Álvarez de Alarcón. Escribano, Escobedo (ARChG, expte. 5.629).

1539/04/23. Granada. Citatoria y compulsoria a Francisco [sic] Pizarro, vecino de Trujillo, y demás personas concernidas, a petición de Juan de Medrano, procurador de Diego de Vargas Carvajal, vecino de Granada, que apelaba de sentencia del teniente de corregidor de Trujillo, sobre la dehesa de María Alonso. Emplazados en 15 días y compulsa en 4. Gálvez, León y Arrieta. Registrador, Lcdo. Juan Álvarez de Alarcón. Secretario, Santander (ARChG, expte. 5.642).

1539/04/26. Granada. Citatoria y compulsoria a Diego de Vargas Carvajal y doña Beatriz de Vargas, su mujer, vecinos de Trujillo, a petición de Antón Hernández, procurador del comendador Hernando Pizarro y de Inés Rodríguez, su hermana, y consortes, vecinos de esa ciudad, así como de Francisco Solano, vecino del lugar de Graz [La Zarza], término de esa ciudad, que apelaban de sentencia el Lcdo. Monleón, teniente de corregidor de esa ciudad, sobre la heredad de María Alonso. Emplazados en 15 días y compulsa en 4. Ramírez, don Juan de Castilla y Deza. Registrador, Lcdo. Juan Álvarez de Alarcón. Secretario, Santander (ARChG, Ibidem). 
rreo mayor de Indias, cargo en que continuarían sus sucesores hasta la segunda mitad del siglo XVIII; ha dejado un palacio importante en Trujillo, erigido al tiempo que el del marqués de la Conquista. ${ }^{13}$

Muy cercanamente emparentados con el conquistador del Perú estaban los Pizarro que en 1538 anduvieron pleiteando por la herencia del comendador Álvaro Pizarro: litigaban las hermanas doña Juana de Aragón, viuda del comendador Sancho Pizarro, y doña Ana, hijas del comendador Álvaro Pizarro, con Diego Pizarro, albacea de éste y tutor de dicha doña Ana, por la partición de su herencia entre ambas y los derechos del cabezalero. ${ }^{14}$ Se había visto la causa en primera instancia ante el Lcdo. Alonso Álvarez, teniente de corregidor, a quien solicitaron que Diego nombrase contador-partidor, junto con Juan de Limosín, designado por ellas. El albacea nombró a Rodrigo de Amarilla. ${ }^{15}$ Realizada la cuenta y partición, el teniente dictó sentencia. ${ }^{16}$

Doña Juana apeló y ambas partes alegaron; doña Juana expuso que se debería haber adjudicado a su parte la mitad de todos los bienes del comendador, sin descontar más que la mitad de las deudas, legados y gastos por el alma del difunto, ni la décima de lo gastado por Diego en cumplimiento del ánima del comendador, ${ }^{17}$

${ }^{13}$ www.turismotrujillo.com/Trujillo/ciudad-y-monumentos/17-palacio-de-los-carvajal--vargas. Sobre esta institución, véase J.M. Vallejo García-Hevia, «El correo mayor de las Indias (1514-1768)», Derecho y administración pública en las Indias hispánicas, Toledo, 2002, II, pp, 1.785-1.810.

${ }^{14} 1538 / 04 / 24$. Granada. Ejecutoria a petición de doña Juana de Aragón, viuda del comendador Sancho Pizarro, contra Diego Pizarro, vecinos de Trujillo (ARChG, expte. 5.695).

Doña Juana de Aragón, hija de Álvaro Pizarro, comendador de Sant'Angelo, había casado con Sancho Pizarro, hijo de Juan Pizarro; del matrimonio nacería Juan Pizarro de Aragón, que casó con doña Juana de Orellana, hija de Juan Pizarro de Orellana. Fue otro de los Pizarro que ha dejado palacio señorial en Trujillo (http://www.turismotrujillo.com/Trujillo/ciudad-y-monumentos/33palacio-juan-pizarro-de-aragon).

${ }^{15}$... declarando ante todas cosas sy la dicha doña Ana quisiere heredar, y en la dicha quenta se hiziese por los dichos contadores, y en defeto de nonbrar los dichos contadores el dicho juez los nonbrase.

${ }^{16}$ Visto este proceso y los autos y méritos d'él, fallo que devo de mandar y mando que al dicho Diego Piçarro se reciban y pasen en quenta de los mrs. que están y fueren a su cargo de los bienes que fincaron del comendador Álvaro Piçarro la mitad de los dineros e hazienda que dello dio a doña Ana de Aragón, su hija del dicho comendador, por quanto parece que los devió aver y le heran devidos por las escrituras de dote que le hizo y otorgó el dicho comendador, su padre, y tanbién se le descargue la décima de todos los mrs. e gasto que hizo el dicho Diego Piçarro en cunplimiento del testamento del dicho comendador Piçarro, como a su testamentario, y, esto recibido en quenta y descargo, sy de algo le fuere hecho alcance, mando que lo dé y pague a la dicha doña Juana de Aragón dentro de tercero día primero siguyente, y, no le aviendo, mando que se guarden y cunplan y executen los pareceres de los contadores y tercero que están en este proceso, sin costas.

17 ... porque se hallaría qu'el dicho comendador no avía dexado bienes algunos rayzes, porque de todos ellos en su vida avía hecho mayoradgo, y lo avía dado a la dicha doña Juana de Aragón en casamiento, solamente avía dexado los muebles, de los quales avía mandado a la dicha doña Juana la mytad y la otra mytad a doña Ana, hermana de la dicha doña Juana, y que de aquéllos avía mandado cunplir su ányma y pagar sus deudas y que hasta tanto que aquello se cumpliese, no se dezía bienes ni se dezía dexar bienes del testamento hasta que sus deudas se pagasen. 
que, respecto a la décima, Diego no tenía ningún derecho a ella, pues en Trujillo no había tal costumbre y, si la hubiera, estaba prescrita y no era razonable ni concurrían las calidades requeridas en derecho en ella. Que en caso de que los albaceas hubieran de llevar décima, no debía ser de los legados y deudas, pues eso pertenecía pagarlo al heredero. Los oidores de la Audiencia granadina dictaron su sentencia de vista. ${ }^{18}$ A pesar de todo lo actuado a continuación la sentencia de revista confirmó la de vista en todos sus términos, librándose luego la correspondiente ejecutoria, de la que se sacó traslado en $1545 .{ }^{19}$

De otro Juan Pizarro que aparece en los documentos de la Audiencia no sabemos de su cercanía a los Pizarro americanos; andaba este trujillano pleiteando en 1547 por una carga de paños. ${ }^{20}$ Mejor informados estamos de otros vecinos de Trujillo, que vieron ejecutoriado su litigio en la década siguiente: se trata de los Chaves. Se habían enfrentado en juicio, por un lado, Nuño Pacheco de Chaves, menor de Cosme de Chaves y de doña Isabel de Chaves, y, por otro, Gonzalo de Torres, también menor, por los bienes de Martín de Chaves el mozo, que resydía en las Yndias del Perul, hijo de Tadeo de Chaves y doña Catalina de Monroy, sus padres, todos ellos vecinos de Trujillo, y nieto de Martín de Chaves el viejo. ${ }^{21}$

Se inició la causa ante el Lcdo. Miguel López de Montoya, juez de residencia de Trujillo, cuando Cosme acudió ante el juez diciendo que Martín el mozo había fallecido, dejando por su heredero universal a Nuño, su primo e hijo de Cosme, según constaba en su testamento, otorgado en Sevilla, en 01/10/1534, ante Pedro de Castellanos, escribano público de esa ciudad; presentó el testamento y pidió se le diese mandamiento de posesión de todos sus bienes. Realizada información del

${ }^{18}$ Deciden revocar la sentencia del teniente, mandando que de todo el dinero y deudas y bienes sobre qu'es este pleyto se cunpla el ánima y mandas del comendador Álvaro Piçarro, ya difunto, padre de la dicha doña Ana de Aragón, y lo que restare se haga dos partes y se dé la mitad a la dicha doña Juana de Aragón y la otra mytad quede con el dicho Diego Piçarro, como curador de doña Ana de Aragón, hija asy mismo del dicho comendador Álvaro Piçarro, y ansy mismo devemos mandar y mandamos qu'el dicho Diego Piçarro, como executor y testamentario del dicho comendador Álvaro Piçarro, aya y lleve solamente la décima de las mandas pías que oviere cunplido y executado como tal testamentario, syn llevar ni sacar décima de otra cosa alguna de los dichos bienes.

Que para la averiguación y liquidación de esto se vuelvan a reunir contadores y tercero, los nombrados ya u otros diferentes, bajo juramento; sin costas. Episcopus tudensis. Lcdos. Melchor de León y don Juan de Castilla (Granada, 24/07/1537).

${ }^{19}$ Dictaron sentencia el Dr. Gálvez y los Lcdos. Melchor de León y don Juan de Castilla (Granada, 02/04/1538), los mismos que rubricaron la ejecutoria.

${ }^{20}$ 1547/04/22. Granada. Receptoria para dos escribanos públicos, a petición de Juan Pizarro, vecino de Trujillo. A las justicias de la ciudad de Trujillo como a las del resto del Reino, comunicándoles cómo ante los oidores litigaban Pizarro y Garci Rodríguez, sobre razón de un fardel de nabales. Rodríguez había pedido poder examinar testigos durante 80 días, a partir del 2 de abril; por lo que ordenan a esas justicias que, si éste se presentase con esa pretensión, procediesen en consecuencia. Que Pizarro pueda estar presente a dichas declaraciones y que jure de calumnia si la otra parte así lo pidiere. Lcdos. Ramírez de Alarcón, don Diego de Córdoba y Lope de León. Escribano, Juan de Sosa (ARChG, expte. 5.712).

${ }^{21}$ 1550/02/21. Granada. Ejecutoria a petición de Nuño Pacheco de Chaves (ARChG, expte. 5.737). Los Chaves han dejado en Trujillo tres edificios singulares, como casas señoriales. 
caso, el juez mandó dar la posesión a Cosme, sin perjuicio de tercero poseedor (Trujillo, 07/09/1539).

Luego compareció el Lcdo. Diego González, en nombre de Gonzalo de Torres, diciendo pertenecerle los bienes de Martín, los quales avía avido de Martín de Chaves, su agüelo, por virtud de la sostitución qu'el dicho Martín de Chaves el viejo avía hecho en su testamento, pidiendo se levantase el mandamiento posesorio concedido. Es presentado testamento de Martín de Chaves, hijo de Gonzalo de Torres y de Catalina de Chaves, vecinos de Trujillo, en 04/05/1523, ante Hernando Mendo, escribano público, en que designaba heredero universal a Martín de Chaves, su nieto e hijo de Tadeo de Chaves y doña Catalina de Monroy; disponía que, si éste muriese sin descendencia, que heredase Gonzalo de Torres, su hijo, sy no como su hijo, syno como por su criado; si éste falleciere sin hijos, que todo fuese a la obra de San Francisco de esa ciudad. El juez, a pesar de ello, ratificó su auto posesorio anterior. La cuestión que se planteaba era quién tenía mejor derecho a heredar, si Nuño, primo del causante, o Gonzalo, nieto de Martín el viejo y hermanastro del occiso; ambos eran hijos de Tadeo, hijo legitimado de Martín el viejo. ${ }^{22}$ Martín el mozo había nombrado heredero a su primo Nuño, pero Martín el viejo, a la muerte de su hijo Tadeo, había designado sucesor a Martín el joven y, en su defecto, a Gonzalo.

La sentencia de vista de los oidores, fue favorable a Gonzalo, imponiéndole silencio perpetuo a Nuño, aunque no se condenó en costas, ${ }^{23}$ pero la de revista, tomando en cuenta nuevas pruebas, revocó la anterior, confirmó el auto posesorio de la primera instancia y atribuyó a Nuño los $4 / 5$ de la herencia y el resto a Gonzalo, además, reservó a las partes su derecho a reclamar la propiedad de los bienes hereditarios, de nuevo sin costas. ${ }^{24}$ Antes de librarse la correspondiente ejecutoria fue preciso que Cosme, en nombre de su hijo, presentase fiadores - Alonso López de Ribera y Juan Remón de Trillo, vecinos de Granada-, que se obligaron junto al mismo Cosme. Lo mismo se exigió a la parte contraria. ${ }^{25}$

${ }^{22}$ La condición legítima de Nuño no se discute. En el caso de Gonzalo no parece defendible. Esta sería su genealogía, a tenor de lo dicho en el documento: Gonzalo de Torres y Catalina de Chaves fueron padres de Martín de Chaves el viejo, que, estando desposado con Constanza de Hinojosa, tuvo con Inés Alonso a Tadeo de Chaves, que sería legitimado en 1506; Tadeo había estado casado con doña Catalina de Monroy, con quien tuvo a Martín de Chaves el mozo, fallecido en el Perú. Gonzalo era también hijo de Tadeo, pero ilegítimo. En el proceso se presentó una carta de legitimación (inserta) de don Fernando, don Felipe y doña Juana, reyes y príncipes de Castilla, a Tadeo de Chaves, hijo de Martín de Chaves, el cual, estando desposado en Trujillo con Constanza de Hinojosa, había tenido a Tadeo con Inés Alonso, siendo soltera y no obligada a matrimonio ni religión; le legitiman en atención a sus buenos servicios, sin perjuicio de los hijos legítimos. Gaspar de Gricio. Lcdos. Zapata y Polanco. Alfonso Cortés. Registrada. Canciller (Dueñas, 28/04/1506).

${ }^{23}$ Lcdos. Arana, Ramírez de Alarcón, Melchor de León y Tello Girón. Dres. Gálvez y Peñas. Lcdos. Hernán Bello, don Juan Sarmiento y Juan Sanz del Corral (Granada, 01/07/1542).

${ }^{24}$ Lcdos. Diego de Deza, Huarte, Arana, Tello Girón y don Juan Sarmiento (Granada, 23/12/1549). $\mathrm{Al}$ parecer, Gonzalo recibió el $5^{\circ}$ de la herencia, destinado a los gastos pro anima de su hermanastro.

${ }^{25}$ Lcdos. Diego de Deza, Tello Girón, Arana y don Juan Sarmiento. Secretario, Barahona. Queda claro que el proceso versaba sobre la posesión, no sobre la propiedad. 
Por esos años consta otro Cosme de Chaves, éste casado con doña Francisca de Torres, vecinos de Trujillo, que demandaron a Diego López de Ribadeneira, sobre razón de trezientos y treinta y tres pesos de oro. ${ }^{26}$

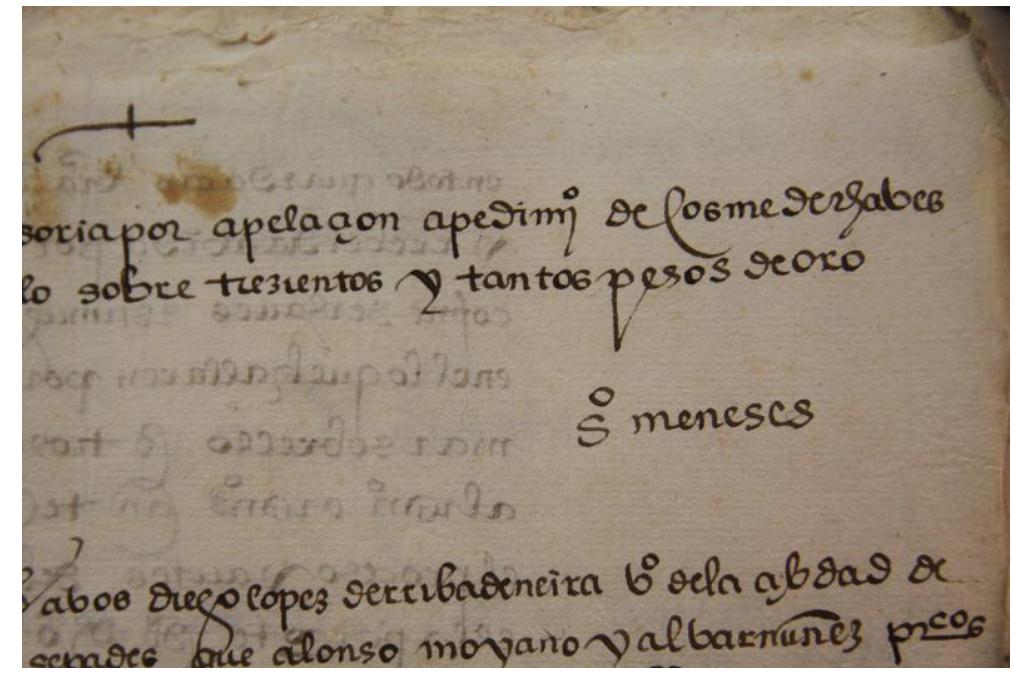

Detalle de la regesta de la requisitoria a Cosme de Chaves (30/09/1552)

\subsection{Geografía hispano-americana}

Relacionados con América y con el oro americano hemos localizado una cierta cantidad de datos que paso a describir. Hay que comenzar por mencionar las localizaciones citadas en esos momentos en que se estaba produciendo la conquista y consolidación de la presencia hispánica al otro lado del Atlántico, geografía aún bastante imprecisa - recuérdese como a Pizarro se le llama en la ejecutoria de 1538 gobernador de las Islas del Perú-; en el área del Caribe se documenta la ciudad de Santo Domingo, así como la ciudad de Cuba; más adelante, con más acierto, se hablará de la villa de La Habana —único caso en que se habla de villa y no de ciudad, tratándose de una localidad americana-. También se menciona el puerto o ciudad de San Juan de Puerto Rico.

Ya en Tierra Firme, además de ciudad de México, se conservan menciones en especial a Centroamérica: la isla de Santa María de Darién, las ciudades de Nombre de Dios y Panamá, la ciudad de Trujillo, en el cabo o provincia de Honduras, la ciudad de Santiago (Guatemala) y el misterioso lugar de Quidagua, sito en la

${ }^{26}$ 1552/09/30. Granada. Citatoria y compulsoria a Diego López de Ribadeneira, vecino de Trujillo, a petición de Alonso Moyano y Álvar Núñez, procuradores de la Audiencia, en nombre de Cosme de Chaves y doña Francisca de Torres, su mujer, vecinos de dicha ciudad, que apelaban de sentencia de la justicia de esa ciudad sobre razón de trezientos y treinta y tres pesos de oro. Emplazado en 15 días y compulsa en 4. Lcdos. Otalora, Jaraba y Castilla. Secretario, Meneses (ARChG, expte. 5.780). 
Nueva España. ${ }^{27}$ Por su parte, en el virreinato del Perú, además de la isla del Perú, se mencionan las ciudades de Quito, Real de Loja y la de los Reyes.

Normalmente, las referencias eran a personas que andaban por esas partes, pero que seguían avecinadas o procedían de España; los lugares de origen más abundantes son los de la Andalucía bética: en el Reino de Jaén, la propia ciudad de Jaén, junto con las de Baeza y Alcalá la Real; en el Reino de Córdoba, además de la capital, Santaella; en la actual provincia de Sevilla, la misma Sevilla, junto con Marchena, Lebrija y Lora del Río, y, finalmente, en la provincia de Cádiz, la ciudad de Cádiz, Jerez de la Frontera y Sanlúcar de Barrameda. En el área extremeña se localiza el segundo foco: en especial, la ciudad de Trujillo y la villa de Zafra $^{28}$-importante núcleo de redistribución de esclavos por aquellos años-, Cáceres y, dentro del territorio de la Orden de Santiago, Mérida, Hornachos y Fuente de Maestre. También ocupa un puesto preeminente la ciudad de Lisboa, importante mercado de esclavos procedentes de África.

Punto aparte merecen las referencias a indios americanos traídos como esclavos a la Península, que serían liberados a partir de 1542. Un último caso curioso lo representa un súbdito de la Tierra del Preste Juan de las Indias, traído del África cristiana por los portugueses, del que me ocuparé al final, a pesar de no tener nada que ver con el mundo americano.

Hay que decir que por aquellos años no fueron pocos los eclesiásticos que se arrogaron, con razón o sin ella, la titularidad de diversos beneficios y dignidades en América, si bien las actividades que documentamos de los mismos se sitúan en España, de donde no habían movido un pie. Esto ocurre en dos ocasiones, la primera de ellas con don Pedro de Mendavia, deán que decía ser de Quidagua, en Nueva España, residente en Baza, donde pretendía actuar como juez conservador del convento franciscano de dicha ciudad. ${ }^{29}$ La otra con don Cristóbal de Pedraza,

${ }^{27}$ Es probable que se tratase de una falsa dignidad. Una búsqueda por la red sólo arroja dos menciones a este término: como apellido se conserva, con su variante 'Quitugua', en la isla de Guam y el norte de las Marianas (numerosas entradas en páginas genealógicas) y como topónimo en Nicaragua, como una pequeña propiedad en la jurisdicción de Camoapa (Hernán Robleto, Nido de Memorias. Poesía y tragedia en el Caribe, http://www.elnuevodiario.com.ni/suplementos/cultural/345559-autobiografia-ficcionalizada-hernan-robleto/).

${ }^{28}$ Las ferias que tenían lugar en Zafra servían para la redistribución de esclavos en buena parte de Extremadura; así lo he constatado, por ejemplo, en dos procesos de 1522 y 1525; en el primero de esos años Diego González de Castejón, vecino de Ágreda, ganadero residente en tierras extremeñas, había adquirido dos esclavas musulmanas (Axixa y Merién) (AHN, OO.MM., AHT, expte. 20.354) y tres años más tarde el cordobés Alonso de Armenta vendía a su esclavo negro Juan en dichas ferias, por el día de San Juan de junio (AHT, expte. 6.945).

${ }^{29}$ 1545/10/22. Granada. Mandamiento para que, si un juez eclesiástico fuere apelado legítimamente, otorgue la apelación; si no la otorgare, envíe el proceso y se remita emplazamiento contra la parte, a petición de fray Diego Ruiz de Zafra. A don Pedro de Mendavia, deán que se decía de Quidagua, en Nueva España, estante en Baza: Santos de Carrión, procurador de fray Diego Ruiz de Zafra, comendador de Sancti Spiritus, vecino también de Baza, había expuesto ante los oidores que se querellaba de él, pues vos, diziendo ser juez conservador, elegido y tomado por parte del guardián y frayles del monesterio de San Francisco de la dicha cibdad, y que a su pedimiento avíades procedido y hecho proceso 
obispo de Trujillo, en la región del Cabo de Honduras de las Yndias del Mar Océano, residente en Sevilla, juez apostólico que decía ser en varias causas, en las que andaba entendiendo en $1543 .^{30}$ No parece que tampoco pusiese un pie en

contra su parte, diziendo que avía puesto las manos en un frayle de la dicha Horden, el qual diz que avía salido a matar a su parte sin causa alguna, y, no enbargante que su parte pareció ante vos, luego que vino a su noticia que conocíades de la dicha causa y declinó vuestra juridición, así por no poder conocer vos della, por no tener dinidad ni concurrían en vuestra persona las otras calidades que de derecho se requieren, a pesar de lo cual rechazó inhibirse, declarándose juez competente; apelado ante el Santo Padre, le denegó la apelación y, procediendo, le había excomulgado, en lo que había cometido fuerza notoria. Solicitaba que se le mandase conceder dicha apelación, revocando todo lo procesado y alzando todas las censuras, y que enviase el proceso original a la Corte.

Así se lo ordenan, so pena de pérdida de naturaleza y temporalidades; si no otorgase la apelación, que en 12 días remita a la Audiencia el proceso original, adelantando primero el peticionario dinero para la persona de confianza que lo trajera. Si enviare el proceso, que en 12 días comparezca en persona o por procurador ante la Corte para litigar con fray Diego. Dres. Peñaranda y Ribera. Escribano, Soto (ARChG, expte. 5.698).

30 1543/05/20. Granada. Mandamiento al obispo de Honduras para que otorgue una apelación y remita el proceso: el fiscal Bracamonte se querellaba de aquél, exponiendo que Juan de Medina clérigo, administrador que dice ser del Hospital de las Cinco Llagas de la ciudad de Sevilla, pidió ant'el teniente de asistente de la dicha ciudad que un Francisco avía asegurado cien ducados que le trahían de las Indias, y se los avían robado, que le condenase en ello, y el dicho Francisco Hurtado alegó que porque otros acreedores de mayor contía le esperavan cierto término, qu'el dicho Juan de Medina le avía d'esperar por el término que los otros acreedores, y por aver reconocido la céldula del seguro el dicho teniente le mandó pagar ante todas cosas los dicho cien ducados, dando el dicho Juan de Medina fianças d'estar a derecho y pagar lo juzgado; así lo proveyó el teniente y fue confirmado en vista y revista por los jueces de las Gradas; Juan prestó fianzas y recibió los ducados. Luego Francisco Hurtado compareció ante el Lcdo. Céspedes, teniente de asistente, y le pidió que compeliese a Juan y a sus fiadores a que pasasen por el concierto que tenían los otros acreedores con él; Juan, pretextando que era administrador del Hospital, eligió por juez conservador a dicho obispo, el cual mandó inhibirse al teniente y fulminó censuras contra él. Teniente y Francisco le pidieron que se inhibiese, etc.

Orden de otorgar la apelación, remitir la causa original a la Chancillería -12 días-, levantar censuras y no conocer, so pena ... y 10.000 mrs. para la cámara. Orden a Juan de Medina de enviar en 10 días a la Audiencia su procurador. Lcdo. don Juan Sarmiento. Dres. Peñaranda y Gálvez. Escribano, Vitoria (ARChG, expte. 5.675).

1543/08/23. Granada. Inserto auto eclesiástico para don Cristóbal de Pedraza, obispo de Honduras, estante en Sevilla, juez subdelegado que se decía en el negocio en cuestión, lo cumpla, a petición de Catalina de Busto, vecina de Jerez de la Frontera: ésta se querellaba de aquél, pues, estando pendiente pleito contra Gonzalo Pérez, vecino de Sevilla, en que le pedía por marido, ante el deán de Cádiz y el prior de Santo Domingo de Jerez, junto al obispo Santuriense, dado por Gonzalo, éste con falsa relación, junto a Isabel de Herrera, que se decía mujer suya, habían ganado un breve en que tomaban por juez al obispo de Arba, el cual había delegado la causa en el obispo de Honduras.

Auto en Granada, 22/08/1543: visto el proceso eclesiástico traído ante ellos por vía de fuerza, a petición de Catalina, declaran que don Cristóbal había cometido fuerza en no otorgar la apelación interpuesta por ésta en 21/06/1543, acordando que se le remita provisión ordenándole que la conceda, reponga los autos y alce las censuras, so pena de pérdida de naturaleza, temporalidades, ser tenido por ajeno y extraño en el Reino, 50.000 mrs. para la cámara. Así se lo mandan, so pena, además, de otros 50.000 mrs. para la cámara. Dr. Miguel de Ribera. Lcdos. Melchor de León y Tello Girón. Secretario, Juan de Velázquez (ARChG, expte. 5.678).

1543/10/08. Granada. Citatoria y compulsoria en proceso eclesiástico a don Cristóbal de Pedraza, obispo de Trujillo, en la región del Cabo de Honduras de las Yndias del Mar Océano, residente en 
América el fiscal del Consejo de Indias, el Lcdo. Ágreda, al que vemos actuando en 1552 , inmerso en actividades ajenas a su cometido. ${ }^{31}$

\subsection{Los procesos por el oro}

En términos generales, documentamos dos clases de motivos litigiosos, uno, la atribución de distintas cantidades de pesos de oro y, otro, los debates sobre la propiedad de bienes radicados, preferentemente, en España, pero también en In-

Sevilla, juez apostólico que se decía ser: ante los oidores de la Audiencia de Granada había comparecido el Lcdo. Luis de Bracamonte, fiscal de la misma, en nombre del Dr. Ortiz, miembro del Consejo y asistente de la ciudad de Sevilla, y del Lcdo. Céspedes, su teniente, y otros jueces reales de Sevilla, exponiendo cómo se querellaba de dicho obispo, pues el dicho asistente y juezes tenían preso en la cárcel real de la dicha cibdad y a un Gonçalo Pérez, vezino della, por cierta requisitoria e ynvocación del braço seglar, hecha y dada por el obispo don fray Dionisio de Ávila y el deán de Cáliz y el prior de Santo Domingo de la cibdad de Xerez, juezes delegados en cierta causa matrimonial que antellos se trataría entre Catalina de Bustos, vezina de Xerez, contra el dicho Gonçalo Pérez, los quales avían mandado prender en execución de cierta sentencia pasada en cosa juzgada que contra el dicho Gonçalo Pérez estava dada, y porque avía muncho tienpo qu'estava descomulgada y tiniendo los dichos juezes presos al dicho Gonçalo Pérez en la cárcel real de la dicha cibdad, en la manera que dicha es, sin ser juez de la causa ni tener juridición para ello, por aver otorgado el apelación que de vos fue ynterpuesta por parta de la dicha Catalina de Busto y averos ynivido del conocimiento y repuesto todo lo hecho en cunplimiento de una nuestra carta y provisión, avíades mandado dar vuestros mandamientos contra los dichos juezes para que luego soltasen al dicho Gonçalo Pérez de la prisión en que lo tenían y para que no obedeziésedes ni cunpliésedes las requisitorias de los dichos obispo fray Dionisio y sus colegas, so ciertas penas y censuras..., a pesar de que le habían pedido que no se entrometiese, había excomulgado y no había concedido la apelación interpuesta, causándoles fuerza notoria.

Orden de remitir a la Audiencia el proceso original en 15 días, so pena de pérdida de naturaleza y temporalidades, de ser habido por ajeno y extraño del Reino, de la merced real y de $50.000 \mathrm{mrs}$. para la cámara. Misma orden a los notarios apostólicos ante quien pasase la causa, en el mismo plazo, pagándole $250 \mathrm{mrs}$. de la traída, estada y vuelta, con cargo a la cámara y gastos de justicia. Emplazado Gonzalo Pérez en el mismo plazo. Lcdos. Cereceda, Melchor de León y Tello Girón. Secretario, Francisco de Escobedo (ARChG, expte. 5.681).

1543/10/12. Granada. Inhitoria a don Cristóbal de Pedraza, obispo de Honduras, estante en Sevilla: para que si de un juez eclesiástico fuere apelado en tiempo y forma, otorgue la apelación y reponga lo causado tras la misma, alzando las censuras eclesiásticas y absolviendo a los excomulgados; o remita el proceso y citatoria contra la parte, a petición de Catalina de Bustos. Lcdo. Cereceda, Tello Girón y Melchor de León. Secretario, Escobedo (ARChG, ibidem).

1543/10/30. Granada. Mandamiento al mismo, para que remita a la Chancillería proceso eclesiástico original de mano del notario de la causa, a petición de Gonzalo Pérez, vecino de Sevilla. Lcdos. Tello Girón, Melchor de León y Ramírez de Alarcón. Secretario, Escobedo (ARChG, ibidem).

31 1552/05/24. Granada. Enplazamiento por nueva demanda, el conocimiento por ser contra la cibdad de Cuenca, a pedimyento del licenciado Ágreda, fiscal del dicho Concejo de Yndias.

Al concejo de Cuenca, a petición de Antón Perez, procurador del Lcdo. Ágreda, fiscal del Consejo de Indias, vecino y 24 de Granada, que le puso demanda ante los oidores, diziendo que les avía ayudado de mucho tienpo a esta parte por avogado en todos los pleytos que avíades tenydo en la dicha nuestra Corte y le dávades en cada un año de salario quatro mill mrs., y del dicho tienpo le restávades deviendo sesenta y quatro mill mrs., poco más o menos, sin querer abonarle la deuda.

Que el conocimiento de la causa pertenecía a la Audiencia por ser concejo el demandado y tratar sobre salario devengado ante la misma Audiencia. Emplazados en 15 días. Lcdos. Lope de León, Castilla y Bartolo Sánchez. Escribano, Gumiel (ARChG, expte. 5.773). 
dias. Vamos a relacionar los primeros, siguiendo un orden cronológico. El primero de estos litigios tiene lugar en 1536: Luis Díaz mercader, vecino de Sevilla, en nombre de Martín de Marchena, estante en el puerto de Nombre de Dios (Panamá), había comparecido ante la justicia de Granada a pedir ejecución en bienes de los deudores de éste - Blas de Rosales, Juan de Alcaraz y Juan de Aparicio - por un total de 140 pesos de oro, a $450 \mathrm{mrs}$. el peso; dado que era una deuda que traía causa de una obligación mancomunada, las diligencias se dirigieron sólo contra Alcaraz y contra su fiador Juan de Carmona, el cual finalmente aceptó pagar la tercera parte de la deuda, más costas y gastos de ejecución, recibiendo por ello carta de lasto con la que perseguir la hacienda de su fiado. ${ }^{32}$

No habían pasado cuatro años, cuando en 1540 se planteó debate entre Pedro de Loaysa, vecino de Trujillo, y Álvaro del Guijo, regidor de Panamá, sobre razón de ciertos pesos de oro. ${ }^{33}$ En el mismo año contamos con el proceso ejecutoriado entre varios vecinos de Guareña, lugar de Medellín, por los derechos debidos por la repatriación desde San Juan de Puerto Rico de cierta cantidad de dinero. ${ }^{34}$

32 1536/10/24. Granada. Luis Díaz mercader, vecino de Sevilla y estante en Granada, en nombre de Martín de Marchena, estante en el puerto del Nonbre de Dios, del Reino de Tierra Firme de las Indias del mar océano, en virtud del poder que tenía sustituido por Hernando de Jerez mercader, vecino de Sevilla, que pasó ante Juan Martínez, escribano público de esa ciudad, por cuanto, a petición de su mandante se había solicitado ejecución contra Blas de Rosales, Juan de Alcaraz y Juan de Aparicio por 140 pesos de oro, a razón de 450 mrs. el peso, y el Lcdo. Pedro de Orduña, alcalde mayor de Granada, dio mandamiento ejecutorio contra ellos, ejecución que se realizó en unas casas que Alcaraz nombró por suyas, en la collación de San Matías (lindes: casas del hospital de Villalobos y del otro lado, casas de la mujer y herederos de Alonso de Alcaraz, padre de Juan), dando por fiador de saneamiento a Juan de Carmona, escribano público de Granada; a la tal ejecución Alcaraz opuso que la obligación en que se basaba no era auténtica ni traía aparejada ejecución, pues en el momento en que la otorgó era menor de 25 años y estaba bajo la patria potestad de su padre; fue recibido a prueba con plazo de 10 días, pasado el cual, el alcalde mandó avivar la voz de la almoneda por 30 pesos de oro a Marchena, con las costas, y en lo demás executado en bienes del dicho Juan de Alcaraz lo dio por libre e por quito dello; no hubo postor a dichos bienes, tasándose las costas en 400 y tantos mrs. Y queriendo sacar mandamiento de apremio contra Alcaraz, como principal, y contra Juan de Carmona, como su fiador, ahora Carmona había expresado su deseo de abonar los 30 pesos, que montaban 13.500 mrs., más las costas, con condición de que le fuese otorgada carta de lasto.

Por tanto, Díaz, en nombre de Marchena, otorga poder a Carmona para cobrar para sí los 13.500 mrs. de principal, los 400 y pico de costas y los 300 que se pagaron al alguacil de dicha ejecución, por cuanto Carmona los había abonado y él quedaba contento del pago.

Testigos, Diego Ruiz, Fernán Sánchez y Juan de Treviño pregonero, vecinos de Granada. Firma Luis Díaz. Ante Martín de Olivares, escribano público (Archivo Histórico de Protocolos de Granada, protocolo Granada-40, fol. 887r-888v).

33 1540/04/02. Granada. Citatoria y compulsoria a Pedro de Loaysa, vecino de Trujillo, a petición de Antón Fernández, procurador de Álvaro del Guijo, regidor de la ciudad de Panamá, que apelaba de sentencia del Lcdo. Juan Vázquez, teniente de corregidor de Trujillo. Emplazado en 15 días y compulsa en 4. Lcdo. Diego Deza. Arrieta. Muñoz. Secretario, Mármol (ARChG, expte. 5.647).

${ }^{34}$ [1543/04/10. Granada] (fecha del último auto, pues falta el pliego final). Ejecutoria a petición de Margarita - Margarida - Alonso y sus hijas contra Juana Sánchez — a ratos González-, viuda 
Se había tratado pleito ante los oidores entre Margarita Alonso, viuda de Sancho Martín, y las hijas de ambos, Mari Gómez, Juana y Beatriz, vecinas de Guareña, y Juana Sánchez, viuda de Alonso Martín Harache, y los hijos de ambos, Juan Román y Alonso Román, también vecinos, que primeramente pasó en Medellín, ante Bernardino García, alcalde ordinario, y llegó ante los oidores por apelación de sentencia dictada por Rodrigo de Mendoza, alcalde ordinario de dicha villa, pues en Medellín, 06/09/1540, comparecieron ante dicho Bernardino las herederas de Sancho y demandaron a Juana y sus hijos, pues 7 años atrás éstos se habían concertado con Sancho para que fuese a las Yndias, al Puerto de San Juan de Puerto Rico, que es en la [isla] de San Juan, a cobrar ciertos pesos de oro y otras cosas propias de Juana e hijos, por fallecimiento de Alonso Martín, prometiendo pagarle por ello a Sancho la cuarta parte de lo que cobrase; y con aquel partido y concierto el dicho Sancho Martín, padre de sus partes, avía ydo a las Yndias, donde el dicho Alonso Martín Arache avía muerto, y por su yndustria e negociación avía cobrado seyscientos castellanos de la hazienda que avía dexado el dicho Alonso Martín Harache, y tenyéndolos cobrados, avía fallescido desta presente vida, estando en las Yndias, en la dicha cobrança; luego Juana mandó por el dinero y se lo trajeron, pero no quería abonar los 150 castellanos que correspondían a los herederos de Sancho.

Dado traslado a la parte de Juana, presentó un escrito de excepciones, negando la existencia del concierto entre las partes;

y porque de los seyscientos castellanos que Alonso Martín Harache tenya y avía
dexado al tienpo de su fin e muerte en la Ysla de San Juan de Puerto Rico, el dicho
Sancho Martín avía cobrado dozientos castellanos y los avía gastado y consumido y
hecho dellos lo que avía querido y no avía acudido con ellos a sus partes, cuyos he-
ran, y se los devía, syendo bivo y, si el muerto se los devía, las partes contrarias,
como sus herederos, heran obligados a pagar los quales les pedía por vía de recon-
vención, mutua petición e nueva demanda; también pedía que declarase a la contra-
ria como no parte.

Rodrigo de Mendoza, alcalde ordinario, pronunció sentencia favorable a Margarita y sus hijas. ${ }^{35}$ Juana apeló, pero fue Margarita quien reclamó que se valorase

de Alonso Martín Harache, y sus hijos, vecinos de Guareña (Medellín). Gratis por pobre (ARChG, expte. 5.673).

${ }^{35}$ Las menores probaron su intención en lo de yuso contenido y Juana e hijos no probaron ni sus excepciones ni la mutua reconvención, por lo que condenaba a éstos a que en 6 días pagasen a aquéllas 100 castellanos de oro por razón del contrato que los dichos Juan Gonçález e Juan Román e Alonso Román hizieron con Sancho Martín, padre de las dichas menores, que es la quarta parte de quatrocientos que en las Yndias cobró, y mando que de los dichos cien castellanos se desqüente el gasto que los dichos Alonso Román e Juan Román e Juana Gonçález hizieron en enviar por ellos a las Yndias quando fue el dicho Alonso Román, la liquydación de lo qual se haga en el dicho térmyno de seys días, mostrando por testimonio e provanças claras los derechos de escripturas y otros gastos que hiziesen en recabdar los dichos quatrocientos castellanos de donde los tenya puestos el dicho Sancho Martín y el gasto y premyo de trabajo de yr y venyr hasta el lugar donde en las Yndias estavan consygnados los dichos quatrocientos castellanos, moderado el tienpo que podría gastar convinyentemente se tasase 
la deuda sobre 600 castellanos, no sobre 400 , con lo que debería abonarle la parte contraria 150 castellanos; añadía que si no había apelado en plazo había sido por causa de su procurador, por lo que pedía restitución a ese momento en nombre de sus menores. A pesar de todas las alegaciones de las partes, la sentencia de vista fue confirmatoria, tan sólo añadió que la cantidad a descontar por las gestiones hechas sería de 30 ducados, en que tasamos y moderamos las costas y gastos que la dicha Juana Sánchez y sus hijos hizieron en enviar a las Yndias por los dichos quatrocientos castellanos, sin costas. ${ }^{36}$ La de revista no añadió cosa alguna.

En el mismo año 1540 hallamos litigando a los vecinos de Trujillo Juan de Torres y Juan de Herrera sobre razón de mill y quinientos castellanos de que se hizo execución en bienes del dicho Juan de Herrera, a pedimiento del dicho, por razón de cierta obligación. ${ }^{37}$ Pasados cinco años, volvemos a encontrarnos con Herrera, pleiteando esta vez con el regidor trujillano Juan Cortés, que le reclamaba 1.300 pesos de oro. ${ }^{38}$ Por una vez contamos con un proceso bastante completo, gracias a una sobrecarta de la ejecutoria, librada en 1547: se había tratado pleito ante la Audiencia entre Juan Cortés — que actuaba en nombre de Juan Pizarro, probablemente, el hermano del conquistador- y Juan de Herrera sobre razón de myll e quinientos pesos de oro, de a quatrocientos y cinquenta mrs. cada uno, de la venta de un cavallo, en que se había dictado sentencia de trance y remate por el Lcdo. Juan Vázquez, teniente de corregidor de la ciudad, y luego por los oidores de la Audiencia en vista y revista, librándose ejecutoria a petición de Juan Cortés, en $18 / 06 / 1544 .{ }^{39}$

Luego fue presentada en Trujillo, en primero de julio siguiente ante el Lcdo. Diego Núñez, teniente de corregidor, por Cortés, para que la ejecutase y le entre-

por dos buenas personas puestas por entranbas las dichas partes; lo que la mayor parte de los tasadores dictase se descuente por el trabajo causado a Alonso Román y consortes. En lo demás da por libres a ambas partes, sin costas. Rodrigo de Mendoza. El bachiller Collado.

Nótese cómo en el castellano de aquella feliz época se decía enviar por ellos, sin duplicar la preposición (a por), algo desgraciadamente tan extendido en nuestros días de habla vulgar.

${ }^{36}$ Dr. Peñaranda. Lcdo. don Juan Sarmiento. Dr. Gálvez. Lcdo. de Frías (Granada, 24/10/1542). La de revista, Lcdo. don Juan Sarmiento. Dr. Peñaranda. Lcdo. de Frías. Dr Gálvez (Granada, 10/04/1543).

Nótese, de nuevo, la frase enviar a las Yndias por los dichos.

${ }^{37}$ 1540/12/04. Granada. Receptoria a las justicias de las Indias y de las islas del Perú, ante dos escribanos: litigaban ante los oidores Juan Torres y Juan de Herrera, vecinos de Trujillo. Se les había recibido a prueba con plazo de un año. Concedida la provisión a petición de Herrera. Arrieta, Corral y Peñas. Secretario, Mármol (ARChG, expte. 5.656).

${ }^{38} 1545 / 01 / 16$. Granada. Citatoria y compulsoria a Juan de Herrera, vecino de Trujillo, a petición de Antón Hernández, procurador de Juan Cortés, regidor de la ciudad, que se había presentado en apelación de sentencia del bachiller Diego de Alvarado, teniente de corregidor de la ciudad. Emplazado en 15 días y compulsa en 4. Dr. Gálvez. Lcdos. Melchor de León y Frías. Secretario, Meneses (ARChG, expte. 5.692).

39 1547/11/25. Granada. Sobrecarta insertos los autos y mandamientos, en el pleito de Juan Cortés regidor con Juan de Herrera, vecinos de Trujillo (ARChG, expte. 5.715). Tal y como nos ha llegado el contenido de esta ejecutoria resulta difícil de entender, pues se nos escapa el contenido del juicio principal. 
gase 21.000 mrs. a partir de un juro sobre las alcabalas del pan de la ciudad, las casas de morada de Juan de Herrera y otros bienes en ella contenidos. El teniente dio mandamiento al alguacil mayor para que le pusiese en posesión de lo pedido. Diego López, alguacil mayor, así lo hizo en manos del procurador de Cortés.

Herrera apeló y se presentó con el proceso, pidiendo que por vía de atentado se revocase todo lo ejecutado; alegado por ambas partes, los oidores revocaron el mandamiento de posesión del teniente y todo lo procedido en virtud del mismo, mandando devolver a Herrera la posesión de todos esos bienes y ordenando a la justicia de Trujillo que viese la ejecutoria y la cumpliese, procediendo contra $\mathrm{He}$ rrera como contra depositario de los mrs. y bienes en cuestión y por la escritura de concierto presentada. Se dio ejecutoria a Herrera para ello. Lo cierto es que, contra lo que parecía en principio, la causa del litigio no estaba en una compraventa, sino en un depósito, que traía causa del transporte de una partida de oro desde el Perú. ${ }^{40}$

Herrera recusó al corregidor, que tomó acompañado a Pedro Mexía de Prado, regidor de la ciudad, los cuales dictaron un auto, mandando a Herrera que en dos días mostrase la escritura de certificación, como estaba obligado por la escritura; pasados los dos días sin hacerlo, que entregase los 1.300 pesos o su justo valor, conforme a la mencionada obligación y escritura de concierto, además de la obligación de depósito. ${ }^{41}$

\footnotetext{
${ }^{40}$ Presentada ante el corregidor, éste ordenó al alguacil mayor devolver los bienes a Herrera, lo que hizo Diego López.

Cortés presentó su ejecutoria y una carta de depósito, pidiendo la ejecución de Herrera por 1.500 pesos de oro, por virtud de una obligación, la qual se avía fecho en los dichos bienes y se avía confirmado en vista e revista por los dichos señores oydores, e los dichos bienes se avían deposytado en poder del dicho Juan de Herrera y fecho sobrello escriptura de depósito, el qual se avía obligado de tener los dichos bienes, e assí mysmo se avía fecho deposytario de myll y trezientos pesos de oro, de a quatrocientos e cinquenta mrs. cada peso, para que, si dentro de dos años y medio no traxese certificación bastante de cómo avía pagado por el dicho cavallo los dichos mill e trezientos pesos, que acudiría al dicho Juan Cortés o a quyen su poder oviese con ellos llanamente e sin pleito alguno, e que avían pasado los dichos dos años y medio e mucho más tienpo sin aver traydo la dicha certificación, como avía quedado sy el dicho su parte le avía requerido al dicho Juan de Herrera con la dicha escriptura de depósyto e no avía querido cunplirla, pidiendo a la justicia de Trujillo que le diese posesión de lo dicho, conforme a la ejecutoria, e hiciese ejecución de ambas ejecutorias, abonándole los 1.300 pesos de principal, con costas.

Luego presentó escritura de requerimiento y la respuesta dada a la misma por Herrera, con la escritura de concierto entre las partes relativa al exhibir la carta de certificación, constituyéndose en el ínterin en depositario sobre los que se había hecho la ejecución [confuso, por estar tachado un trecho].

${ }^{41}$ Notificado a Herrera, su procurador presentó un escrito, en que dixo qu'el pedimyento fecho por la parte contraria para qu'el dicho su parte presentase la dicha certificación que tenya de la paga del dicho cavallo a Francisco Martín de Alcántara de los mill e trezientos pesos de oro, que avía pagado por él para Juan Piçarro, por quyen el dicho Juan Cortés lo pedía dentro de cierto término, so ciertos apercibimientos, para lo cual presentó un proceso, en que estaba contenida dicha certificación, e porque los testigos deponyan qu'el cavallo rucio que se avía conprado por el dicho Juan Piçarro, e que era de Francisco Martín de Alcántara, e parescía en el dicho proceso un conoscimiento original que se avía presentado e se avía mandado bolber a la parte, firmado del dicho
} 
Alegaron ambas partes hasta concluir, dictando sentencia el bachiller Diego de Alvarado, teniente de corregidor de Trujillo. ${ }^{42}$ Cortés alegó que el teniente se había extralimitado en su función, que era la de ejecutar las dos ejecutorias de la Chancillería. Que lo alegado por Herrera ya lo había presentado en la instancia anterior. Que no avía traydo contento de Juan Piçarro ni constava que estoviese pagado de los $m r s$., por lo que el teniente no había tenido causa para sentenciar lo que sentenció. Pedía sobrecarta de la anterior ejecutoria, sin embargo de todo lo procesado después. Se dio traslado en rebeldía a Herrera, que no contestó. Concluso, dictaron sentencia. ${ }^{43}$ Herrera se presenta en suplicación, alegando que la sentencia del teniente había pasado en cosa juzgada; que había presentado la certificación del pago, que le liberaba de la deuda, cumpliendo así el asiento hecho con Cortés. ${ }^{44}$

Dado traslado a Cortés, alegó y pidió ser recibido a prueba. Los oidores acuerdan denegar dicha petición y concluyen para definitiva. En Granada, 15/11/1547:

Francisco Martín de Alcántara e de tres testigos, reconoscidas las firmas por muchos testigos, en que avía recibido el precio del dicho cavallo del dicho Juan de Herrera, que volvía a presentar para que vieran que no había necesidad de una nueva certificación ni prueva, pues constava por el dicho escriptura del vendedor del caballo, e porque se provava con muchos testigos qu'el dicho su parte traya del oro del dicho Juan Piçarro, e avía pagado el dicho cavallo, e que lo avían avido por bueno el dicho Juan Piçarro e recibido el dicho cavallo he dicho palabras de enojo, porque lo avía dexado de pagar de los dineros que enbiava a España, e porque los dichos testigos dezían qu'el dicho su parte era cierto y que no aría falta en ello, porque no parescía otra paga del dicho cavallo de otra persona, sino del dicho su parte. Solicitaba que se declarase haber traído la certificación y haber cumplido con la escritura de depósito, libre de lo pedido, con costas a la parte contraria.

42 Atento que entre Cortés y Herrera hubo contrato en que éste se constituyó como depositario de 1.300 pesos, de modo que, si en dos años y medio Herrera no mostrase certificado de cómo había pagado esa cantidad por Juan Pizarro a Cortés, se los abonase a éste, pero, si mostrase tal certificado, que Cortés dejase libres a Herrera libres los bienes que tenía hipotecados al pago del depósito. Falla que Herrera mostró la certificación de haber pagado en plazo el dinero, en nombre de Juan Pizarro, por lo que alza el depósito y da por libres los bienes hipotecados a Herrera, sin costas (Trujillo, 23/12/1545).

Cortés apela y se presenta ante los oidores de la Audiencia. Se le dio citatoria y compulsoria para Herrera, que no compareció.

${ }^{43}$ Granada, viernes, 17/06/1547: revocan la sentencia del teniente y mandan dar la sobrecarta pedida de la ejecutoria de 18/06/1544, con orden a las justicias de Trujillo de cumplirla en 9 días, haciendo pago a Cortés de los pesos de oro o, en su lugar, las casas y juros en que se había hecho ejecución por dicho dinero.

${ }^{44}$... porque, aunque no oviera la paga del dicho cavallo sobre la cantidad del oro qu'el dicho Juan de Herrera avía traydo a España del Perú, sobre que avía sido el dicho pleito, en que entre las dichas tres pieças y plancha de oro, el dicho Juan Cortés avía traydo pleito con su parte ante los del nuestro Consejo de Yndias, ante los quales avía pedido lo mesmo que pedía al presente y por sentencia y carta executoria que por ellos se avía dado a su parte le avían dado por libre dellos e mandado que lastando en quenta de los gastos que avía fecho en traer el dicho oro de la provincia del Perú a estos nuestros Reynos e de lo que se le avía tomado en el Reyno de Portugal e pagado por el dicho Juan Piçarro, y porque estante lo susodicho el dicho Juan Piçarro y el dicho Juan Cortés, en su nonbre, eran obligados a pagar a su parte los mill e trezientos castellanos que avía pagado por el cavallo rucio qu'el dicho su parte avía conprado de Martín de Alcántara, los quales le ponya por demanda por vía de reconvención, pidiendo se revocase el auto anterior y se confirmase la sentencia previa. 
confirman en grado de revista su sentencia anterior, reservando su derecho a Herrera a reclamar donde le conviniera los 1.300 castellanos por la compra del caballo rucio a Martín de Alcántara, que había pedido por reconvención. ${ }^{45}$

El siguiente caso conocido tuvo lugar en la ciudad de México y fue planteado por doña María de Figueroa, vecina de Granada, madre y curadora de Gabriel de Moscoso; se trata de un exhorto dirigido a la Audiencia de México y otras justicias para que remitan a la Casa de la Contratación de Sevilla 340 pesos y 2 tomines de oro que se habían depositado como bienes de García de Cárdenas receptor, que murió allá tomando una probanza del duque de Béjar en un proceso con la ciudad de Toledo, además de cualesquier otros bienes y escrituras que hubieran quedado del dicho Cárdenas, además del testamento que hizo antes de morir, para que traído se dé a quien le corresponda, transportado a costa y riesgo de la misma hacienda. ${ }^{46}$

Este proceso entre el duque y Toledo versaba sobre el señorío de la Puebla de Alcocer y otros lugares comarcanos. ${ }^{47}$

Un año más tarde, en 1545, pendía pleito ante los oidores entre Isabel Sánchez Barba, viuda de Fernando del Castillo, vecina de Lebrija, por una parte, y,

${ }^{45}$ A petición de Cortés, se libra la sobrecarta de la ejecutoria. Rubrican los Lcdos. Melchor de León, don Juan Sarmiento y Frías. Secretario, Meneses.

46 1544/03/15. Granada. Al presidente y oidores de la Audiencia de México de la Nueva España de las Indias del Mar Océano y demás justicias de esa ciudad y del resto de las Indias: ante la Chancillería de Granada había comparecido Alonso Moyano, procurador de doña María de Figueroa, vecina de Granada, como madre y curadora de Gabriel de Moscoso, y expuso que García de Cárdenas, receptor de esta Audiencia, que fue a Indias a tomar cierta probanza, a petición del duque de Béjar, en el pleito que trataba con la ciudad de Toledo sobre ciertas villas, lugares y términos; estando entendiendo en ello en la ciudad de México, el receptor murió y dejó por su albacea a Diego Hernández, escribano real, al que se había tomado cuenta de los bienes y dinero dejados por Cárdenas ante Luis Marín y Juan de Burgos, alcaldes de México, y ante Juan de Zaragoza, escribano público, el cual había sido alcanzado en dicha cuenta en 340 pesos y 2 tomines de oro, que corre en esa dicha cibdad de México, dejando por depositarios de los mismos a Alonso de Mérida, tesorero de la Casa de Moneda de México, y a Antonio Isidro, vecino de la misma, según un testimonio presentado, que iba signado por dicho Zaragoza.

El duque y sus criados habían adelantado a Cárdenas para que fuera a México 680 ducados, de los que habían quedado cuando falleció 380 ducados, cantidad de la que el duque hizo donación a Antonio de Moscoso, su criado, marido de doña María de Figueroa y padre de Gabriel de Moscoso, su heredero. Solicitaba que los dichos 340 pesos, dejados en moneda por Cárdenas, se remitiesen a la Casa de Contratación de Sevilla y de los mismos se le hiciese pago de los 380 ducados donados por el duque a su difunto marido.

Orden de sacar de depósito el dinero y, a costa y riesgo de los peticionarios, remitirlo en el primer navio o navios que binyeren a la dicha Casa de la Contratación de Sevilla, para hacer pago de la donación. Orden a los jueces y oficiales de esta Casa de retener el dinero hasta que se les haga saber lo acordado sobre ello. Deza. Huarte. Arana. Escribano, Juan de Simancas.

Diéronse dos provysiones de un tenor por ser para las Yndias (ARChG, expte. 5.685).

${ }^{47}$ En la segunda mitad de abril de 1542 Fernandálvarez de Mesa, procurador de la ciudad de Toledo, obtuvo del Consejo de Órdenes sendas compulsorias para el encargado del archivo de la Orden de Santiago a fin de que le facilitase traslado de ciertos documentos que la ciudad necesitaba para su pleito con el duque de Béjar sobre la Puebla de Alcocer y otros pueblos (AHT, expte. 78.304). 
por otra, Pedro del Castillo, por sí y en nombre de Ana de Lugo, su hija, de Diego Martín Beato, por sí y en nombre de Antona Fernández, su hija, de Fabián del Castillo y Ana del Castillo, mujer de Francisco del Ojo, de Antón Martín de Tarifa clérigo y María del Castillo, vecinos de la villa, el convento femenino de La Concepción de la villa, la cofradía y hermandad del Santísimo Sacramento, de Pedro del Castillo, Ana del Castillo, Antón del Castillo, Isabel Pérez, Pedro Vidal, los beneficiados de San Benito y las doncellas casadas y dotadas de lo mandado por Gonzalo del Castillo, difunto, vecinos de la villa, en su rebeldía, sobre razón de los bienes e hazienda que quedaron e fincaron del dicho Gonçalo del Castillo, fijo de la dicha Ysabel Sánchez Barba, que la susodicha pide e demanda.

Fabián había expuesto que para probar su intención tenía necesidad de que de los libros de la Casa de Contratación se sacase del registro que había hecho dicho Gonzalo del Castillo Barba, hijo de Isabel, del oro e plata que traxo al tienpo que vino en España de las Yndias, y de los poderes que Isabel había otorgado para cobrar el dinero que su hijo había traído de las Indias. También había solicitado que Isabel jurase de calumnia las posiciones que le pusiese. ${ }^{48}$

Siguiendo en Lebrija, cinco años después, ${ }^{49}$ pleitearon Álvaro de Paz y Blas de Cisneros, estantes en la ciudad de Santiago (Guatemala), en las Indias, contra Juan de Albarracín y Juana de Lugo, su mujer, y Fabián del Castillo y Jacomina de Lugo, su mujer, vecinos de la villa sevillana, que llegó por apelación,

sobre razón que parece que en la dicha villa de Sanlúcar de Barrameda, a doze días del mes de março del año pasado de mill e quinientos e quarenta e un años, ante el jurado Diego de Almonte, alcalde hordinario y de la justicia de la dicha villa, pareció por parte de los dichos Álvaro de Paz y Blas de Cisneros y presentó un contrato de obligación contra el dicho Alonso de Lugo, el thenor siguiente. ${ }^{50}$

${ }^{48}$ 1545/03/09. Granada. Compulsoria a las justicias de la Casa de Contratación de Sevilla para que, ante escribano, hagan sacar traslado de ciertas escrituras, citada la parte, y para que Isabel Sánchez Barba jure de calumnia, a petición de Francisco del Castillo y consortes, vecinos de Lebrija.

Es dispuesto como se pide. Lcdos. Arana, Huarte y Diego de [León]. Secretario, Adarve (ARChG, expte. 5.694).

${ }^{49}$ 1550/05/05. Granada. Ejecutoria a petición de Álvaro de Paz y Blas de Cisneros, estantes en la ciudad de Santiago de Guatemala, contra Juan de Albarracín y Juana de Lugo, su mujer, y Fabián del Castillo y Jacomina de Lugo, su mujer, vecinos de Lebrija, en su ausencia y rebeldía (ARChG, expte. 5.741).

${ }^{50} 1537 / 12 / 24$. Santiago de Guatemala

"Sepan quantos esta carta vieren cómo yo, Alonso de Lugo, estante al presente en esta cibdad de Santiago desta provincia de Guatimala, otorgo e conosco que devo de dar e pagar a vos, Álvaro de Paz, y a vos, Blas de Cisneros, estantes en esta dicha cibdad, qu'estays absentes, como si fueses presentes, e a qualquier de vos, sin qu'el uno tenga poder del otro ny el otro del otro, o a quyen poder de vos o de qualquier de vos oviere y esta carta presente vos mostrare, conviene a saber, ciento e sesenta pesos de oro de mynas, de ley perfeta, fundidos e marcados de quatrocientos e cinquenta mrs. cada un peso, los quales vos devo y son por razón de un cavallo de color castaño e dineros que me prestastes por me hazer plazer e buena obra, que todo lo valió e montó e yo de vos lo recibí, e son en my poder, de que soys e me otorgo por de vos por bien contento e pagado, entregado a toda my voluntad, e renuncio que no pueda dezir ny alegar que los non recebí de vos, según 
Los actores pidieron mandamiento ejecutorio y les fue dado, haciéndose ejecución en dicha villa, en la ribera, con dos tiendas y dos puertas a las calles, en la calle de los Bretones, donde vivía Hernán de Niebla, que las tenía alquiladas. Leonor de Lugo se opuso, pues esas casas las habían alquilado y comprado estando casada con Jácome Dinarte, y al tiempo que falleció Francisco Dinarte, su suegro, habían hecho división y partición entre sus hijos, en las que no había tenido parte Jácome Dinarte, su marido, por ser de sus otros hermanos y de su madre; éstos las habían vendido a Fernando Melchur cambiador, a quien Jácome las había comprado, estante el matrimonio, del cual habían tenido tres hijos; su marido había fallecido 22 años atrás y luego dos de sus hijos, habiendo sucedido ella en las dos terceras partes de la mitadd de las casas, como su madre y heredera legítima,

y a la parte que de las dichas casas pertenecía al dicho Álvaro de Lugo, su hijo, ella tenya mejor derecho que las partes contrarias, porque para en quenta dello le avía dado mucha más cantidad que lo que al dicho su hijo le podía pertenecer.

Se mandó hacer trance y remate, pero entretanto Leonor había fallecido, siendo sucedida por Ana y Jacobina de Lugo, por lo que fueron notificados sus maridos, Juan Albarracín y Fabián del Castillo, que también se opusieron a la ejecución. Recibidos a prueba, realizaron y presentaron probanzas y concluyeron.

El Lcdo. Briceño, corregidor de la villa, dictó sentencia: declara probada la intención de los ejecutados y revoca el mandamiento ejecutorio y lo efectuado en virtud del mismo, guardando su derecho a los actores para que actuasen donde les conviniere, sin costas $(02 / 11 / 1547)$. El procurador de los ejecutantes apela ante el duque de Medina Sidonia, señor de Sanlúcar, que confirma la sentencia anterior, sin costas. Rubrican don Alonso de Cárdenas y el Lcdo. Altamirano, jueces del duque de Medina Sidonia (Sanlúcar, 09/04/1548). ${ }^{51}$

dicho es, e, si dixere e alegare, que non vala, y a esto en especial renuncio la exeución de los dos años que ponen las leyes e derecho de la pecunya non vista ny contada ny recebida ny pagada.

Los quales dichos ciento y sesenta pesos de oro de mynas deste dicho oro otorgo e prometo e me obligo de vos los dar e pagar en esta dicha cibdad o en otra qualquier parte o lugar de los Reynos e señoríos de S.M. que lo pidiéredes e demandáredes en paz y en salvo e sin pleyto alguno, de oy día qu'esta carta hes fecha ende en adelante dende un año conplydo primero siguiente, so pena del doblo e costas, e la dicha pena pagada o no, qu'esta carta e lo en ella contenido vala e sea firme en todo e por todo, e sy no lo cunpliendo e pagado, como dicho es, por esta carta doy todo poder conplido a todas e qualesquier alcaldes e juezes e justicias de S.M. desta dicha cibdad como de otro qualquier fuero e juridición que sean al fuero e juridición de las quales e de cada una dellas me someto con my persona e bienes, renunciando, como espresamente renunciamos my propio fuero e juridición, domycilio e vezindad e me someto al fuero e juridición desta dicha cibdad e de otras qualesquier partes e lugares donde fuere presentada, en cuya juridición ...» [lectura complicada].

Testigos, Juan Márquez, Hernán Díaz y Diego Díaz, vecinos. Alonso de Lugo. Ante Antón de Morales, escribano público y del concejo de Santiago, provincia de Guatemala. Alonso de Cazalla, escribano público de Sevilla.

${ }^{51}$ De nuevo apelan, ahora ante la Chancillería, dándose carta de emplazamiento; fue notificada y acusaron sus rebeldías. Alegaron que las casas-tiendas eran de Álvaro de Lugo; que éste había deja- 
Por su sentencia de vista los oidores declaran que los jueces del duque juzgaron mal, por lo que revocan su sentencia, declarándola nula junto con la del corregidor Briceño, ordenando se prosiguiera con la ejecución, haciendo trance y remate de los bienes designados, con pago a los demandantes de los 160 pesos de oro de minas, sin costas. ${ }^{52}$

En la misma época, no lejos de allí, pleitearon Leonor Díaz, como cesionaria de Marcos y Diego Bachicao, sus hijos, vecinos de Sanlúcar de Barrameda, contra Juan Gallego, vecino de Jerez de la Frontera. ${ }^{53}$ Primeramente se había tratado entre Leonor Bachicao, mujer de Bartolomé de Hontanas, vecina del Puerto de Santa María, y el dicho Juan Gallego, que llegó por apelación ante los oidores de la Audiencia,

sobre razón que paresce que en la dicha cibdad de Xerez, a dos días del mes de setienbre del año pasado de quarenta e seys, ante el licenciado Bartolomé de Nanda, alcalde mayor de la dicha cibdad, paresció el dicho Bartolomé de Hontanas, en nonbre de la dicha su muger, e fizo presentación de una carta misiva de Hernando Bachicao, por la qual paresce que dio y entregó al dicho Juan Gallego ochenta pesos de oro en las Yndias, para que se los diese a la dicha Leonor Bachicao... ${ }^{54}$

El Lcdo. Ponce de Cabrera, alcalde mayor de Jerez, dicta sentencia: Leonor Díaz probó su intención, no así Gallego, al que condena a entregar a Marcos y Diego Bachicao, hijos y herederos de Juan Bachicao, en 6 días las 2/3 partes de los 73 pesos recibidos en las Indias de Hernando Bachicao, recibiendo en quenta las dos tercias partes de los mrs. qu'el dicho Juan Bachicao recibió del myllar de madera; de lo demás da por libre a Gallego, sin costas (Jerez, 11/05/1548).

do sus bienes a su madre, que había aceptado su herencia. Las ejecutadas estaban en la misma posición que su difunta madre, como herederas suyas. Se dio traslado a la parte contraria, fueron recibidas a prueba las partes, aunque no realizaron probanza alguna.

${ }^{52}$ Rubrican el Dr. Covarrubias de Leyva y el Lcdo. de Frías (Granada, 29/03/1550), dictada en rebeldía de los ejecutados. Los actores, una vez pasada la sentencia en cosa juzgada, piden se les libre ejecutoria. La firman Lcdo. Becerra. Dr. Covarrubias de Leyva. Lcdo. de Frías.

${ }_{53}$ 1550/08/04. Granada. Ejecutoria a petición de Leonor Díaz, cesionaria de Marcos y Diego Bachicao, sus hijos, vecinos de Sanlúcar de Barrameda, contra Juan Gallego, vecino de Jerez de la Frontera (ARChG, expte. 5.748).

${ }^{54} \mathrm{El}$ alcalde mayor mandó comparecer al demandado, que declaró que había recibido sólo 73 pesos de oro para que los entregase a Juan Bachicao, al que los había dado y tenía conocimiento de ello; que cuando se los dio no conocía a dicha Leonor. Dado traslado a la parte contraria, ambas partes presentaron escrituras y alegaron, hasta que compareció Leonor Díaz, como cesionaria de sus hijos, presentando un escrito de oposición, por el que dijo que Juan Gallego había recibido en Indias 73 pesos de Fernando Bachicao para entregarlos a Juan Bachicao, según estaba acreditado, pero negaba validez al albalá presentado por el demandado, pues estaba firmado por Juan, que no sabía escribir. Pedía fuese condenado a entregarle los pesos con costas.

Dado traslado a Gallego, contesta que había entregado el oro a Juan Bachicao en Sanlúcar el 1537, según albalá firmado por el receptor y por Juan de Oviedo, cura de la iglesia mayor de esa villa, e por averle constado del dicho pagamento a la dicha Leonor Bachicao, por sí y en nonbre de sus herederos e con sus poderes se avían concertado en veynte ducados e le avían dado por libre e quyto. Presenta la escritura del concierto. Alegan hasta concluir. 
Gallego apela ante los oidores, aunque Leonor presenta petición, como el demandado.

Sentencia de vista: confirma la de primera instancia en todos sus extremos,

y por quanto la parte del dicho Juan Gallego no provó lo que ante nos se ofreció a provar, le condenamos en un ducado de oro, que por nuestra sentencia de prueva le fue puesto de pena si no lo provase, el qual mandamos que dé y pague al receptor de las penas de cámara desta Corte luego como sobrello fuere requerido, sin costas. Lcdos. Melchor de León y don Juan Sarmiento (Granada, martes, 09/07/1549).

Sentencia de revista: confirma la de vista,

con este aditamento y declaración: que como por el licenciado Cabrera, alcalde mayor en la dicha ciudad de Xerez, que nos por la presente confirmamos, condenó al dicho Juan Gallego en las dos tercias partes de los setenta y tres pesos de oro, sobre qu'es el dicho pleito, recibiendo en cuenta dellos la dicha Leonor Díaz los mrs. del myllar de la madera, devemos mandar y mandamos que sea y se entienda las dos tercias partes de la mytad de los dichos setenta y tres pesos de oro, recibiendo la dicha Leonor Díaz en quenta de las dichas dos tercias partes de mytad de los dichos setneta y tres pesos de oro, catorze ducados de la dicha madera y quatro ducados que paresce que recibió el dicho Bachicao. Sin costas. Didacus, episcopus abulensis. Lcdo. Huarte (Granada, 29/03/1550). ${ }^{55}$

También en 1550 hallamos nuevo proceso por la traída de oro a España entre vecinos de Hornachos y de Zafra, ${ }^{56}$ pleito comenzado ante bachiller Juan González de Medellín, alcalde mayor del condado de Feria, y llegado ante los oidores por apelación: en Zafra, en 17/09/1547, compareció ante dicho juez Diego Fernández Borrabe, vecino de Hornachos, procurador de Isabel Palafrexa, Rodrigo del Barco y Fernando del Barco, hijos del difunto Rodrigo del Barco, vecino de Hornachos, y presentó una carta misiva que había enviado Luis Fernández del Barco, hermano de su parte, dirigida a su padre, diciéndole que le había enviado con el Lcdo. Juan Sánchez médico, vecino de Zafra, 103 pesos de oro de Quito, que valían a $450 \mathrm{mrs}$. cada uno, que no se los había entregado; por haber fallecido Rodrigo ese dinero pertenecía a sus hijos. Solicitaba que se compeliese al médico a que reconociese la carta y les hiciese entrega del dinero. Presentada al médico, éste la reconoció. Se había iniciado como causa civil, sin embargo, más tarde los actores — ¿moriscos? - cambiaron de opinión. ${ }^{57}$

\footnotetext{
${ }^{55}$ Leonor pide ejecutoria. Rubrican Didacus, episcopus abulensis [Diego Álava Esquivel, 15481558]. Lcdos. Huarte y Castilla.

${ }_{56}$ 1550/11/15. Granada. Ejecutoria a petición de Hernando, Isabel y Rodrigo del Barco, hijos de Rodrigo Fernández del Barco, vecinos de Hornachos, contra el Lcdo. [o bachiller] Juan Sánchez médico, vecino de Zafra (ARChG, expte. 5.752).

${ }^{57}$ En 26/09/1547 comparece de nuevo Borrabe y acusa criminalmente al médico, diciendo que un día de abril de ese año Luis había entregado a Juan, estando en el puerto de Nombre de Dios (Panamá), en las Indias, para que los trajese a su padre 103 pesos, a $450 \mathrm{mrs}$./peso, además de otros 15 pesos en una cadena de oro, que valdría 100 ducados, y cuatro anillos, que valdrían dos castella-
} 
El médico negó la acusación, rechazando que el curador fuera parte; que no podían acusarle de hurto — porque de derecho, aunque uno pudiese acusar crimynalmente de hurto, requeríanse dos cosas copulativamente, que fuese señor e oviese poseydo la cosa de que acusava de hurto y estos nunca avían poseydo ni avían sydo señores de lo que pedían-. Que no había llegado a recibir el dinero. Que, en todo caso, sería causa civil y no criminal - y este hera el caso de Juan de Ymola [† 1436] y ningund antiguo ny moderno discrepava en quanto a no ser parte parte para acusar el que avía de recibir, e todos concluyan en esto-, por lo que se le agraviaba en tenerle preso. Que no se podía interponer la acción criminal sin haberse sustanciado previamente la civil. Que no se podía suponer en él semejante delito, por ser letrado, rico, abonado, buen cristiano, temeroso de Dios y no acostumbrado a semejantes cosas. De su fama y forma de vivir no se presumía tampoco, antes solía perder de su hazienda que no tomar la ajena, e bastava su confisyón para mostrar su ynocencia.

En un nuevo escrito del reo niega los hechos de nuevo;

... y el dicho de Francisco Sanches Holgado no le podía parar perjuzyio, porque, demás de que tenía dada ynformación de cómo avía sydo sobornado e corronpido y hera honbre de poco crédito, deponía cosas no verisymiles, porque no se conpadescían que, aviendo jugado un honbre toda su fazienda, que cient ducados que le quedasen los enbiase graciosamente a nadie.

En 20/10/1547 el juez dicta sentencia. ${ }^{58}$ A petición de Juan de Santa Cruz, procurador en la Audiencia, por Borrabe y los menores, se libra citatoria y compulsoria, siendo traído el proceso por Hayti. Alegaban que Juan Sánchez avía cometido hurto en aver contratado y no dado los dichos pesos de oro e falsedad

nos, además de una carta misiva, en que se contenía todo lo susodicho e cómo los avía traydo todos para el dicho Rodrigo Fernandes e a los dichos sus partes. El médico se había quedado con todo ello y, añadiendo delito sobre delito, había fabricado una carta falsa, en que Luis decía haberle tomado todo ello, dinero y joyas, así como un conocimiento falso, por lo que era merecedor de penas corporales. Solicitaba que fuese puesto en prisión. Dada información de ello por el acusador, el juez mandó prender al galeno. Éste dio también información, dándose requisitoria para que los menores comparecieran en 3 días a poner acusación. Francisco Hayti, curador de los menores, se presentó y reiteró la misma acusación.

58 ... el qual al principio se trató ante my civilmente por vía executiva e después se yntentó crimynalmente, visto lo alegado por anbas las partes fasta la conclusyón d'él, etc. Fallo que de de declarar e declaro el acto e remedio civil yntentado en esta cabsa contra el dicho licenciado obstar e ser perjudicial a la acusación crimynal contra el dicho licenciado, puesta por parte del dicho Fernando del Varco e sus consortes e del dicho su curador, e que no se devyó ny pudo yntentar el juyzio crimynal pendiente el civil, por ende, que devo mandar e mando sobreseer e sobreseo el dicho juyzio crimynal fasta qu'el juyzio civil primeramente yntentado se fenesca e determyne entre las partes, e que no a lugar de se proceder en anbos juyzios comulativamente, como está yntentado, syn que precediese avocación y desistimiento del primero pleito cevil, fecho con conoscimiento de causa, de consentimiento del dicho licenciado, al que mando dar en fiado a carcelero comentariensis, que lo reciban presos en la cárcel pública de esta villa ... Juan González bachiller.

Fianza: Zafra, 25/10/1547, Juan Gutiérrez, Fernán Vázquez, Juan de Villarreal y Rodrigo Mexía, vecinos, mancomunados. Testigos, Diego López borceguinero, Simón de Chaves y Melchor Rodríguez. 
en el conoscimyento e carta que falsamente avía fecho, e así devía estar preso e a vuen recaudo, y el pleito civil no podía ynpedir esto ni dar la causa a dicha sentencia, que no había remedio para intentar la acción civil contra el hurto y la falsedad cometidos. ${ }^{59}$ Los oidores dictan auto (Granada, 16/03/1548), recibiendo a prueba a las partes. Plazo de 40 días y que juren de calumnia, conforme a la ley de Madrid. Versaría lo probado tanto en lo civil como en lo criminal, sin embargo del pronunciamiento del bachiller Juan González de Medellín.

Sentencia de vista: los demandantes probaron su intención, no así el licenciado, al que condenan a que en 9 días, tras serle mostrada la correspondiente ejecutoria, abone a los menores de Rodrigo Fernández del Barco los 103 pesos de oro, con las costas. ${ }^{60}$

Un año más tarde, en 1551, documentamos otro proceso, esta vez enfrentando a vecinos de las ciudades de Jaén y México, del que sólo se conserva una provisión de trámite. ${ }^{61}$ Casi simultáneamente se estaba sustanciando otro litigio entre Diego de Miraval de Villavicencio, veinticuatro de Jerez de la Frontera, y las viudas y menores de Alonso Guerra y Francisco Román, vecinos de Cáceres, por 900 y tantos pesos de oro. ${ }^{62}$ Ya en 1552 eran Francisco Cabrón, regidor de Cádiz,

${ }^{59}$ Los alcaldes del crimen dan traslado a la parte contraria. Contesta que la causa era civil y que estaba en fase probatoria, pidiendo se repartiese a los escribanos de la Audiencia y se diese parte al relator para que informase. Responden los actores que la causa no debía remitirse a los oidores. Los alcaldes ordenaron que los acusadores continuasen su acción ante quien les pareciere. Se dirigen entonces ante el presidente y oidores y piden lo que tenían pedido. Éstos ordenan dar traslado a la parte contraria, que niega la apelación, pidiendo se declarase desierta y firme la sentencia de primera instancia. Santa Cruz, en nombre de los actores, concluye.

${ }^{60}$ Don Juan Sarmiento licenciado. Lcdo. Becerra. Dres. Covarrubias de Leyva y Peñaranda.

Ambas partes suplican y vuelven a alegar.

Sentencia de revista (Granada, 21/10/1550), confirmatoria de la anterior, sin costas. Lcdos. Becerra y Tello Girón. Dr. Covarrubias de Leyva.

Los demandantes piden y obtienen el libramiento de la ejecutoria, declarándose que las costas hechas por éstos ascendían a los 12.000 mrs., pagaderos también en plazo de 9 días. El médico debería permanecer preso hasta tanto hiciese efectivo el pago o fuese ejecutado en sus bienes. Firman Lcdo. Tello Girón. Dr. Covarrubias de Leyva. Lcdo. Becerra. Secretario, Nájera.

${ }^{61}$ 1551/02/28. Granada. Citatoria y compulsoria a Juan de Saavedra, vecino de Jaén, defensor de los bienes y hacienda de Álvaro de Saavedra, su padre, difunto, a petición de Diego de Arroyal, procurador de Jerónimo de Mendoza, vecino de la ciudad de México, que apelaba de sentencia de la justicia de Baeza, sobre razón de cient mill maravedís. Emplazado en [número de día olvidado] y compulsa en 4. Lcdos. Castilla, Jaraba y don Juan Sarmiento. Secretario, Meneses (ARChG, expte. 5.755).

${ }^{62}$ 1551/11/14. Granada. Citatoria a Diego de Miraval de Villavicencio, veinticuatro de Jerez de la Frontera, y a doña María de Guzmán, su mujer, a petición de Antón Hernández, procurador de las viudas e hijos de Alonso Guerra y Francisco Román, vecinos de Cáceres, que apelaban, pues en cunplimiento de un auto pronunciado en la dicha nuestra Audiencia por el qual en efecto se remytió esta causa a las justicias de hesa ciudad, para que, llamadas y oydas las partes, hiziesen justicia a sus partes, pidieron execución en las personas y bienes del dicho Diego de Myraval y doña María de Guzmán, como herederos de los bienes de Diego García Palomino, ya difunto, por contía de novecientos y tantos pesos de oro, contenydos en ciertas obligaciones que se presentaron, e que aviendo el corregidor de la dicha cibdad rescibido a prueva el negocio con término de quatro me- 
y Rodrigo de Vargas, vecino de la ciudad, quienes andaban en pleitos por 400 pesos de oro. ${ }^{63}$ Para 1553 encontramos en Marchena a Mari García e hijos litigando con Antón Sánchez barbero por 9 pesos de oro fino. ${ }^{64}$

Llegó a la Chancillería por apelación de sentencia del Lcdo. Gonzalo Hernández, juez en Marchena:

\begin{abstract}
y por la parte qu'el dicho Antón Sanches cobró por el dicho Alonso García, por una parte treinta y cinco pesos de oro fino, de quatrocientos y cinquenta mrs. cada peso, e un cavallo que vendió del dicho Alonso García, e por otra parte cobró de Luis de Luna treinta y nueve pesos del mesmo precio e valor, que son todos sesenta y quatro pesos, e parece que todos pagó por mandado de un alcalde de la Ciudad Real de la provincia de [Loja $]^{65}$ de las Yndias por el dicho Alonso García, cinquenta y cinco pesos que le devía el dicho Alonso García a Francisco García, que queda deviendo a la dicha muger e hijos del dicho Alonso García diez y nueve pesos del mesmo precyo e valor, por lo que condena a Sánchez a pagar a Mari en 3 días 19 pesos de oro fino, o $450 \mathrm{mrs}$. por cada uno, sin costas (09/04/1546).
\end{abstract}

Sánchez apela, pero la alzada es declarada desierta, por lo que los oidores devuelven al juez la causa para que ejecute su propia sentencia, condenando en costas al apelante (Lcdos. Huarte, Arana y Salas, en 04/11/1552). El procurador de Sánchez suplica, dictándose sentencia de revista, en que confirman la sentencia anterior y vuelven a condenar al apelante en las costas de la instancia (Lcdos. Fernán Bello, Bártulo Sánchez y Ramírez de Alarcón, 06/12/1552). ${ }^{66}$

Sin embargo, el proceso más sonado por esos años tuvo lugar entre 1540 y 1549, implicando a Juan Pérez de Valenzuela y al gobernador Pedro de los Ríos, ${ }^{67}$

ses para verificar las dichas escripturas e mandándoles entregar a sus partes, dando fianças que las ternán dentro de los dichos quatro meses, y trayéndolas rescibidas y dando la dicha fiança y quiriendo sus partes yr a hazer su provança, el dicho corregidor tornó a mandar que no se le diesen las dichas escripturas y que os otorgava a vosotros año y medio de térmyno para haser vuestra provança, todo por conplazer al dicho Diego de Myraval, por ser como diz que soys favorescido en esa dicha ciudad e veynte y quatro della e sus partes forasteros. De todo ello habían apelado ante los oidores y presentado testimonio.

Emplazados en 15 días. Lcdos. Tello Girón y Oviedo. Dr. Covarrubias. Secretario, Adarve (ARChG, expte. 5.765).

${ }^{63}$ 1552/09/17. Granada. Citatoria y compulsoria a Francisco Cabrón, regidor de Cádiz, a petición de Cristóbal de [Lido], procurador de Rodrigo de Vargas, también vecino, que apelaba de ciertos autos y mandamientos dados contra su parte y a favor de aquél [no se expresa juez ni causa: en el encabezamiento: sobre .cccc. pesos de oro]. Emplazado en 15 días y compulsa en 4. Lcdos. Arana, Jaraba y Otalora (ARChG, expte. 5.781).

${ }^{64}$ 1553/01/11. Granada. Ejecutoria a petición de Mari García, viuda de Alonso García Valiente el mozo, e hijos, Leonor Gómez, Nicolás García Valiente y Catalina García, vecinos de Marchena, contra Antón Sánchez barbero, estante en la villa, sobre razón de 9 pesos de oro fino (ARChG, expte. 5.788).

${ }^{65}$ Hay un borrón sobre el nombre. Seguramente sea Loja (Ecuador), fundada por Gonzalo Pizarro en 1546 como La Zarza, entre dos zonas donde se había encontrado oro. Dos años después fue refundada por el vencedor de Pizarro en otra parte.

${ }^{66}$ Costas tasadas en 617 mrs. Firman la ejecutoria los mismos Lcdos. que la sentencia de revista.

${ }^{67}$ Se trataba de Pedro Gutiérrez de los Ríos y Aguayo (Córdoba, 1499 - Córdoba, 1549), veinticuatro de la ciudad y señor de las Escalonias; fue gobernador de Castilla de Oro (1526-1529), teso- 
ambos vecinos de Córdoba. Valenzuela le reclamaba cierta cantidad al gobernador, para lo que necesitaba recibir testimonio de personas radicadas en Panamá. ${ }^{68}$ Gracias al siguiente documento conservado sabemos que Juan era hijo de doña Catalina, difunta esposa de Pedro, y deseaba recibir su herencia, para lo cual necesitaba saber el conjunto de oro, plata, perlas, joyas y demás bienes traídos de Panamá en los últimos 14 años, bienes que estaban en posesión del gobernador. ${ }^{69}$ Pasados cinco años, cambian los actores y el objeto del litigio, pero se mantienen las anteriores pulsiones familiares: doña Leonor de los Ríos, vecina de Panamá, sabedora del proceso que seguía su padre, el gobernador, con los aspirantes a la herencia de Valenzuela, decide personarse y aceptar la herencia con beneficio de inventario. ${ }^{70}$

rero de la provincia de Nicaragua (1534-1541) y participó en la guerra civil peruana en el bando de los Pizarro (1542-1547).

Sobre estos linajes cordobeses pueden rastrearse algunos datos, tanto en la bibliografía genérica sobre la Córdoba bajomedieval, como en algunos trabajos específicos, como, por ejemplo, los de José de la Torre y del Cerro, «Cordobeses que intervinieron en el descubrimiento, conquista y colonización del Perú», Boletín de la Academia de Ciencias, Bellas Letras y Nobles Artes de Córdoba, XXXVIII, 1933, pp. 77-124, o de Margarita Cabrera, «Oligarquía urbana y negocio inmobiliario en Córdoba en la segunda mitad del siglo XV», Historia. Instituciones. Documentos, XX, 1993, pp. 107-126. Debo estas referencias a la generosidad de Enrique Soria.

${ }^{68}$ 1540/04/29. Granada. Receptoria para las justicias de la ciudad de Panamá, como del resto de los Reinos y señoríos de las Yndias de la Nueva España del mar océano, ante dos escribanos, a petición de Pedro de los Ríos. Pendía pleito ante los oidores entre Juan Pérez de Valenzuela y el gobernador Pedro de los Ríos, vecinos de Córdoba, sobre razón de ciertos mrs. que la parte del dicho Juan Pérez de Valençuela le pide e demanda, siendo las partes recibidas a prueba, con plazo de un año. Lcdo. de Frías. Dres. Velasco y Miguel de Ribera. Secretario, Medina (ARChG, expte. 5.648).

${ }_{69}$ 1541/09/28. Granada. Compulsoria a los contadores y factores de la Casa de la Contratación de Sevilla, a petición de Juan Pérez de Valenzuela, para sacar traslado de algunas escrituras. Ante la Chancillería litigaba Valenzuela con el gobernador Pedro de los Ríos, sobre razón de ciertos bienes $y$ herencia, en que aquél tenía necesidad de sacar de los libros de esa Casa todas las partidas de oro, plata, perlas y otras joyas y cosas traídas en los últimos 14 años de la ciudad de Panamá, en las Indias, así en vida de doña Catalina, madre de Valenzuela y mujer del gobernador de los Ríos, como después de su muerte, bienes que se habían puesto en posesión de éste último.

Dr. Gálvez. Lcdos. don Juan Sarmiento y Corral. [Escribano], Medina (ARChG, expte. 5.663).

1542/02/27. Granada. Sobrecarta de mandamiento a los contadores y factores de la Casa de la Contratación de Sevilla. Juan Pérez de Valenzuela expuso cómo había obtenido otra provisión anterior para que los contadores y factores de esa Casa exhibiesen ciertos libres y le diesen traslado de cierta partida de oro, plata, perlas y otras joyas y cosas que le habían traído de la ciudad de Panamá en los últimos 14 años, a fin de presentarlo en pleito que trataba ante la Chancillería con el gobernador Pedro de los Ríos, veinticuatro de Córdoba; había sido notificada, pero no habían querido cumplirla, diziendo que no se acostunbrava a hesivir ny sacar de hesa dicha Casa ningund libro ny registro, porque el contador della tenía abtoridad para sacar las dichas fees.

Orden de ver la provisión previa y cumplirla, sacando el traslado en pública forma, como acostumbrasen. Lcdos. Tello Girón, Ramírez de Alarcón y Melchor de León. Secretario, Francisco López de Medina (ARChG, expte. 5.666).

${ }^{70} 1547 / 10 / 07$. Granada. Citatoria por nueva demanda, en caso de corte, por ser contra un veinticuatro de Córdoba, a petición de doña Leonor de los Ríos, vecina de Panamá, por un cortijo. 
Hasta donde nos indican los datos de estas provisiones, Valenzuela era hijo de Alonso Hernández y doña Catalina, la cual casó en segundas nupcias con el gobernador, que a la muerte de esta señora se quedó con los bienes de ésta en perjuicio de Valenzuela; fallecido éste, litigaba doña Leonor, su hermanastra y heredera universal, con García Muñoz, acreedor de Juan Pérez, y con el veinticuatro Luis Pérez/Páez de Castillejo, que pretendía suceder en los bienes de un supuesto ma-

A Luis Pérez Castillejo, veinticuatro de Córdoba: el procurador de doña Leonor expuso que había llegado a sus oídos el pleito que se seguía en la Audiencia entre el gobernador Pedro de los Ríos, padre de doña Leonor, contra García Muñoz, como acreedor a los bienes y herencia de Juan Pérez de Valenzuela, hijo de su parte, y el dicho Luis Pérez, que pretendían la heredad y dehesa del Montón y otros bienes de mayorazgo. Por el interés que tenía en la causa se opuso al proceso y ratificó todo lo hecho en su favor sobre dicha dehesa y heredad, con todos sus pastos, huertas, casas y otros aprovechamientos, con todo los demás bienes dejados por el causante al tiempo de su fallecimiento, como heredera universal suya, cuya herencia aceptaba con beneficio de inventario. No se trataba de bienes de mayorazgo, sino libres, ni a ello perjudicava el testamento en la dicha causa presentado, que dezían que avía hecho Alonso Hernández, padre del dicho Juan Pérez, porque por él no avía vínculo ni mayorazgo ni licencia nuestra, e, aunque del dicho testamento se pudiesen sacar algunas palabras de mayorazgo desde decomiso, aquello avía sido gravamen en la legítima del dicho Juan Pérez, que sin aver hecho declaración alguna ley lo avía avido por no puesto ... Solicitaba la restitución de todos los bienes dejados por Juan Pérez al morir, con todo lo rentado desde entonces, declarando no ser bienes de mayorazgo y pertenecer a su parte. Por ser pleito dependiente del principal y ser veinticuatro de Córdoba, pide se tramite como caso de corte.

Emplazado en 12 días. Lcdos. Lope de León, Frías y Pedrosa. Secretario, Juan Suárez (ARChG, expte. 5.721).

1549/00/00. Granada (fechas de día y mes en blanco). Compulsoria a Alonso de Toledo, Alonso de Córdoba y Pedro Rodríguez, escribanos públicos de Córdoba, a petición de doña Leonor de los Ríos, mujer de don Arias de Acevedo, regidor y vecino de la ciudad de Panamá, en pleito con Luis Páez del Castillo, veinticuatro de Córdoba, sobre el heredamiento y cortijo de Montón de Tierra. Doña Leonor necesitaba traslado de un inventario hecho ante Alonso de Toledo por Luis Páez, de las escrituras que había recibido Juan Pérez de Valenzuela, junto con el auto que estaba al pie, que había pasado en 10/04/1546; también un arrendamiento ante Alonso de Córdoba, otorgado por Juan de Gaete a favor de Martín Alonso de la Corredera, en 13/11/1520, de la huerta de la Corredera, linde con tierras del dicho cortijo del Montón; y una escritura que ante Pedro Rodríguez había presentado Catalina Ruiz y Alonso de la Corredera, su hijo, en un pleito que habían tratado con Luis Páez, firmada de Gonzalo Hernández, escribano público de Córdoba.

Compulsa en 3 días. Lcdos. Salas, Arana y Huarte. [Escribano], Suárez (ARChG,expte. 5.725).

1549/03/13. Granada. Compulsoria al escribano concernido, a petición de doña Leonor de los Ríos, mujer de Arias de Acevedo, regidor y vecino de la ciudad de Panamá, en pleito con Luis Páez de Castillejo, vecino y veinticuatro de Córdoba, sobre razón del cortijo y eredamiento que dizen Montón de la Tierra. Doña Leonor dijo necesitar sacar de las notas y registros de Pedro Abad, difunto, escribano público que fue de Córdoba, traslado de una escritura que había pasado entre Luis de Berrio y Martín Alonso de la Corredera y otros, por la que se avían dado de provida una huerta qu'está junto al dicho Montón de la Tierra.

Compulsa en 3 días. Lcdos. Deza, Arana y Huarte. Secretario, Juan Suárez (ARChG, expte. 5.727).

Doña Leonor Gutiérrez de los Ríos y Aguayo era hija del mencionado gobernador Pedro de los Ríos y de su segunda esposa, doña Catalina Arias de Saavedra y Castillejo; fue segunda señora de Castillejo y casó con Arias de Acevedo, regidor de Panamá y Cuzco, ancestros de los marqueses de la Puebla de los Infantes (Sevilla). 
yorazgo. En Chancillería no parece que se conserven los procesos o ejecutorias de estos dos procesos.

Por último, en tierras castellano-nuevas contamos con la ejecutoria del proceso seguido entre 1549 y 1556 por la familia Naranjo, establecida en Almodóvar del Campo, y Alonso Jiménez, vecino de La Membrilla del Tocón, por los 10.000 pesos de oro y los 15 esclavos, además de ropas y bestias dejados en la ciudad de Panamá, a su muerte, por Cristóbal Naranjo. ${ }^{7}$

El procurador de los Naranjo demandó a Jiménez,

\begin{abstract}
diziendo que sus partes eran hijos lexítimos de Cristóval Naranjo y de Catalina de Vargas, su padre e madre, y que era ansí qu'el dicho Cristóval Naranjo falleció en las Yndias, en la cibdad de Panamá, y que al tienpo de su fin e muerte dexó por sus bienes diez mill pesos de oro y quinze esclavos, que valían tres mill castellanos, y otras ropas $y$ vestias, que valían más de otros quatro mill castellanos, y en el testamento que hizo, debaxo del qual murió, avía dexado a sus partes por sus hijos y erederos y al dicho Alonso Ximénez por su albacea testamentario, el qual se avía entrado en todos los dichos bienes y se los avía tenydo y poseydo munchos años, y puesto que por sus partes avía sido, y requerido que les diese cuenta con pago dellos, no avía querido hazer, como hera honbre muy rico y faborecido, les avía dado unas cuentas finxidas e simuladas y las avía traudo en munchos pleytos y hecho concierto con sus partes, en todo lo qual sus partes avían sido leso y elificados y él, en su nonbre, pedía restitución, anulando todo lo actuado y pagando las cantidades y bienes expresados por su justo valor, que estimaba en 7.000 castellanos, con todo lo que habían rentado después; que se difiriese a su parte juramento in litem por cantidad de 17.000 pesos de oro, más los intereses desde el día que tomó posesión de todo.
\end{abstract}

Pasado un mes, compareció el procurador de Jiménez y negó la demanda: que no tenía cargo de responder ante ellos, que, si alguna cuenta tenía que darles, ya lo había hecho,

y porque, conforme a derecho y a la costunbre que se tenya en la cibdad de Panamá, qualquiera persona que tenya cuydado de allegar y cobrar la hazienda de algún difunto y tenella en pie para sus herederos y cunplir el ányma y testamento del testador, se le avía de pagar su trabaxo, y por la dicha costunbre se declarava que era la décima parte de los bienes, y pues su parte avía cobrado ciertos bienes del dicho Cristóval Naranjo y los dio y restituyó a las partes contrarias, sin que le pagasen la décima ny otra cosa alguna y eran obligados a le pagar ..., solicitaba que se diese la cuenta dada por buena y se les impusiese silencio perpetuo, reclamando el pago de la décima de la herencia, por reconvención.

Como cabía esperar, la sentencia de vista fue favorable a los demandantes: los Naranjo probaron, Jiménez, no, por tanto le condenan a que en 9 días dé cuenta con pago a los demandantes de 120.000 mrs.

${ }^{71}$ 1556/01/22. Granada. Ejecutoria a petición de Isabel Naranjo y hermanos, Inés, Hernando y Martín Naranjo, vecinos de Almodóvar del Campo (Orden de Calatrava), hijos menores de Cristóbal Naranjo, contra Alonso Jiménez, vecino de La Membrilla (ARChG, expte. 5.732) (mal colocada; este es el único documento manejado para el período 1554-1556). 
que Cristóval Naranjo mandó a Ynés Gonçález e a Beatriz de Vargas, agüela e tía de la dicha Ysabel Naranjo y sus consortes, e de lo demás pedido e demandado por parte de la dicha Ysabel Naranjo y sus consortes contra el dicho Alonso Jiménez les devemos absolver y absolvemos, dámosle por libre e quito dello y ponemos perpetuo silencio a los dichos..., sin costas. ${ }^{72}$

La sentencia de revista sólo contenía una pequeña salvedad: confirmatoria de la de vista, con un aditamento:

que así mismo mandamos al dicho Alonso Ximénez dé quenta a los dichos Ysabel Naranjo y consortes de los mrs. qu'el dicho Christóval Naranjo mandó que se diesen a Pasqual, su criado, dando el susodicho fianças que cada y quando que pareciere el dicho Pasqual o otra persona que por el lo oviese de aver los dichos mrs., se los darán e pagarán, y que las dichas fianças se obliguen que sacarán a paz y a salvo al dicho Alonso Ximénez de los mrs. contenidos en la dicha manda del dicho Pasqual ..., sin costas. ${ }^{73}$

Así pues, aunque no en todos los casos se expresa con claridad, al no tratarse nuestros documentos sino de provisiones ordinarias, las más de las veces, es evidente que no pocos de los litigios habidos entre españoles de España y de América tienen que ver con el transporte de cantidades de oro a través del Atlántico, que provocaron que la codicia del transportista - tal y como hemos visto en el caso de Barrantes - se disparara intentanto detraer todo o parte del metal traído o, en su caso, cobrar derechos de una cierta importancia por los portes.

\subsection{Procesos por bienes hispano-americanos}

Si en el capítulo anterior he recogido las referencias a procesos entre distintas personas en torno a diversas cantidades de oro, generalmente, expresadas en pesos, por lo que entiendo que estamos en presencia, cuando no se dice con precisión, de metal precioso traído de América, en este epígrafe voy a exponer las noticias recogidas sobre litigios habidos entre españoles de los dos continentes por la propiedad de distintos bienes, conexos o no con la llegada de oro americano.

${ }^{72}$ Lcdo. Tello Girón. Dr. Covarrubias de Leyva (Granada, 16/02/1554).

Ambas partes apelaron. Jiménez vuelve a insistir en los gastos que había tenido en administrar la herencia en Panamá, por lo que merecía cobrar la quinta o la décima parte del caudal; que ya había dado cuenta a los demandantes.

Los Naranjo dicen que la parte contraria tenía confesado deberles 147.895 mrs., más intereses, que eran bienes legados a menores y huérfanos; porque quando el parte contraria avía dado la dicha quenta en Panamá se le avía dado su décima e trabaxo, como se vería de la cuenta e inventario de la parte contraria cuando los mostrase. Que no se le debía nada, pues había hecho negocio para sí mismo - granjeado - con esos bienes. Solicitaba se le condenase en aquella cantidad; $e$ porque la parte contraria por sus cartas mensajeras se avía ofrecido de traer los dineros a sus partes de gracia, lo qual aceptava, por lo qual no se le avía de dar el trabaxo ...

${ }^{73}$ D. episcopus abulensis. Lcdos. Becerra y Tello Girón. Dr. Covarrubias de Leyva. [fecha en letra ilegible; interlineada]. Se libra la ejecutoria a petición de los Naranjo. Rubrican la ejecutoria Lcdos. Girón y Becerra. Dr. Covarrubias de Leyva. Registrador, Lcdo. Molina. Secretario, Nájera. 
Comenzando por los bienes sitos en América, hay que mencionar la inhibitoria para la justicia eclesiástica que se dictó en 1552 por la Chancillería a instancia de Hernando de la Sal, estante en la ciudad de Nombre de Dios, en Panamá, que litigaba con el obispo de esta ciudad por la propiedad de un solar para casas. Se trata del documento que se daba habitualmente para los recursos de fuerza. ${ }^{74}$ Una provisión parecida fue librada un año más tarde, a instancias de Diego Hernández de Ocaña, estante en Ciudad de los Reyes, en el Perú, que era acusado de algo no expresado ante la justicia eclesiástica de Sevilla por Íñigo López Catano, vecino hispalense. ${ }^{75}$ Así mismo, en el tercer y último caso conservado sobre litigios entre españoles de ambos lados del mar estamos en presencia del mismo tipo de documento; en este caso en el mismo año 1553 Diego Gutiérrez Vidal, vecino de la Fuente del Maestre, solicitaba la intervención de los oidores de la Audiencia gra-

${ }^{74}$ 1552/02/05. Granada. Inhibitoria: para que, si de un juez eclesiástico fue apelado en tienpo y en forma, otorgue la apelación e enbíe el proceso original y asuelva por .XL. días y enplazamiento contra la parte en forma, a pedimiento de Hernando de la Sal, vezino del Nonbre de Dios [Panamá].

A Hernando de Saucedo, canónigo de la iglesia de Sevilla, a petición de Alonso Moyano, procurador de Hernando de la Sal, estante y residente en la ciudad de Nombre de Dios, del Reyno de Tierra Firme, en las Yndias del Mar Océano, que presentó una petición ante los oidores querellándose de aquél, en que expuso que trataba pleito con don Pablo de Torres, obispo de Panamá, y su provisor y fiscal por causa de un solar de casas que él tenía y poseía; dicho obispo había dictado cierta sentencia, de la que él había apelado ante la Santa Sede; el Papa había dado un breve, encomendando que conociese de dicha causa en grado de apelación el comendador de Sancti Spiritus de Sevilla, el cual había aceptado la causa y dado citatoria y compulsoria para el obispo, el cual había contradicho el breve y el juez apostólico; además, el obispo ganó otro breve del nuncio, dirigido al canónigo Saucedo, ante quien el querelloso se había presentado pidiendo que declinase jurisdicción y remitiese la causa al comendador, lo que no quiso hacer, apeló ..., cometiendo fuerza y agravio.

Orden de conceder la apelación y reponer la causa a su estado anterior, enviando el proceso original ante los oidores en 12 días con el notario de la causa —o éste la envíe con otra persona, al que en Granada le tasarían y pagarían el gasto- - y levantar excomuniones durante 40 días.

Lcdos. Arce de Otalora y Tello Girón. Dr. Covarrubias de Leyva. Secretario, Meneses (ARChG, expte. 5.770).

${ }^{75}$ 1553/01/30. Granada. Ynserto el auto eclesiástico pronunciado en esta Corte a pedimyento de Diego Hernández de Ocaña, residente en la Ciudad de los Reyes.

Al Dr. Escobar, vicario general del arzobispado de Sevilla, que seguía proceso contra Diego Hernández de Ocaña, estante en la Ciudad de los Reyes (en la provincia del Perú) y contra la justicia seglar de dicha ciudad, caso que fue cometido a los oidores de la Chancillería, los cuales dictaron un auto (Granada, 27/01/1553): visto el proceso traído ante ellos por vía de fuerza, a petición del Dr. Navarrete, fiscal en esa Corte, y del reo, que le seguía la justicia eclesiástica de Sevilla, a petición de Íñigo López Catano, vecino de Sevilla, declaraban que en no haberle concedido dicha justicia las apelaciones interpuestas había cometido fuerza, por lo que mandaron al vicario general que se las otorgase y que alzase cualesquier censuras o entredichos puestos contra él, so pena de pérdida de naturaleza y temporalidades, siendo considerado ajeno y extraño del Reino, y de $50.000 \mathrm{mrs}$. para la cámara. Firma Francisco de Gumiel.

Ordenan al vicario que, siendo requerido por el reo, cumpla el auto anterior, so pena de otros $50.000 \mathrm{mrs}$. para la cámara. Al escribano que la notificase que dé testimonio, so pena de su merced y de 10.000 mrs. para la cámara.

Lcdos. Botello Maldonado, Ramírez de Alarcón y Lope de León. Escribano, Gumiel (ARChG, expte. 5.789). 
nadina para oponerse a la fuerza que le causaba el convento [dominico] de San Juan de Puerto Rico, en la causa por los bienes de fray Pedro de Aguilar. ${ }^{76}$

Ciñéndonos ahora a los bienes situados en la Península, hay que comenzar por citar el proceso habido en Baeza en 1539 entre Isabel Hernández y la mujer e hijos de Antonio Román de Argüello; éstos pidieron plazo ultramarino para hacer sus probanzas en la Isla de Santa María [de Darién], tomando declaración a Diego de Villanueva cambiador. ${ }^{77}$ Tambien dentro del Reino de Jaén, en 1551, litigaba el síndico de Alcalá la Real con el Lcdo. Alonso Pérez Cerrato, residente en la Audiencia de Honduras, sobre distintas tierras y veredas alcalaínas. ${ }^{78}$

En tierras cordobesas hallamos en 1549 a Catalina Ruiz la Coronada, vecina de Santaella, que deseaba tomar testigos en ciudad de México contra Francisco de Aguilar menor, vecino de Écija, por motivos no expresados. ${ }^{79}$

${ }^{76}$ 1553/05/05. Granada (mal colocada: pudiera ser 1552). Inhibitoria: para que, si de un juez eclesiástico se apeló en tienpo, otorgue e reponga, o enbíe el proceso, y enplazamiento a la parte, y absuelva por quarenta días, a pedimiento de Diego Gutiérrez Vidal, vezino de la Fuente el Maestre.

Al Dr. Escobar, juez apostólico que decía ser y provisor de la ciudad de Sevilla: Diego Gutiérrez Vidal, vecino de la Fuente del Maestre, se había querellado de él ante los oidores, diciendo que procedía contra su parte a petición de los frailes y convento de San Juan de Puerto Rico, en las Indias, diciendo tener su parte ciertos bienes de fray Pedro de Aguilar, pertenecientes al convento; Diego había declinado la jurisdicción de aquél, que había seguido adelante, causándole fuerza y agravio. Solicitaba se remitiese la causa a las justicias de la Fuente del Maestre.

Orden de otorgar la apelación y reponer los autos, o enviar el proceso en 12 días para que la Audiencia determine si hubo fuerza o si había actuado jurídicamente, enviándolo el notario de la causa o quien éste designare - tasado y pagado por la Audiencia - y levantar excomuniones durante 40 días - la había pedido por 80 días-; emplazan a la parte del convento a que envíe en el mismo plazo procurador. Lcdos. Castilla, Jaraba y Frías. Secretario, Barahona (ARChG, expte. 5.774).

77 1539/07/12. Granada. Receptoria a la justicia de la ciudad de Baeza como a las del resto del Reino: pendía pleito ante los oidores entre Isabel Hernández, mujer de Juan de Uceda, y la mujer e hijos de Antonio Román de Argüello, vecinos de Baeza, sobre razón de ciertos bienes; se había dado sentencia, que fue suplicada por la parte de éstos, concluyeron y fueron recibidas a prueba en plazo de 40 días; la parte de éstos pidió le fuera concedido cuarto plazo de término ultramarino para tomar un testigo que estava en las Yndias, en la ysla que llaman de Santa María, rechazado antes, lo pide de nuevo, diciendo estar prestos a dar información: el testigo se llamaba Diego de Villanueva cambiador.

Comisión a la justicia baezana para recibir información sobre el artículo de este testigo, en el plazo de los 40 días, a contar desde el 23 de junio pasado. Dr. Peñaranda. Lcdo. Muñoz. Dr. Gálvez. Registrador, Lcdo. Juan Álvarez de Alarcón. Secretario, Barahona (ARChG, expte. 5.644).

${ }_{78}$ 1551/10/22. Granada. Citatoria y compulsoria al concejo de la ciudad de Alcalá la Real y a su síndico, a petición de Hernando de Córdoba, procurador del Lcdo. Alonso Pérez Cerrato, presente en la nuestra Audiencia que reside en la provincia de Honduras, en las Yndias, que apelaba de sentencia dada contra él y ciertos arrendatarios suyos por el Lcdo. García Miranda de Paz, alcalde mayor de la ciudad, sobre ciertas tierras y amojonamientos dellas y sobre ciertas veredas.

Emplazados en 15 días y compulsa en 4. Lcdos. Hernán Bello, Ramírez de Alarcón y Lope de León. Secretario, Juan [Moreno] (ARChG, expte. 5.763).

79 1549/01/12. Granada. Receptoria para la justicias y dos escribanos para hacer probanzas en las Indias, a petición de Catalina Ruiz la Colorada, vecina de Santaella. A las justicias de la ciudad de México y a todas las de estos Reinos y señoríos: pendía pleito ante la Audiencia entre Francisco de Águilar menor, vecino de Écija, y Catalina Ruiz en razón de ciertos bienes. Ésta deseaba que fueran examinados testigos en Ultramar, durante el año que se les había concedido de plazo para 
Ya en el área del Reino de Sevilla contamos con varias referencias: a la altura de 1543 doña Beatriz de Zúñiga deseaba tomar testigos en Indias en el litigio que mantenía con Alonso Gutiérrez de Cervantes, ambos vecinos de Lora, por el patronato de una capellanía. ${ }^{80}$ Cuatro años antes, en Sanlúcar de Barrameda eran Constanza Bernal y Hernando de Rosas quienes pleiteban por la tutela que éste había ejercido sobre aquélla, de resultas de lo cual necesitaban interrogar testigos en la ciudad de Santo Domingo ${ }^{81}$ La misma necesidad de ayudarse de testigos ultramarinos tuvo Pedro Fernández Ramos, curador de Gonzalo Sayago, vecinos de la Fuente del Maestre, en tierras santiaguistas de Extremadura, en pleito con los parientes de su pupilo, vecinos de la Puebla de Sancho Pérez. ${ }^{82}$

Así pues, además de documentar los problemas que traían aparejadas las probanzas ultramarinas, esta sección nos ofrece noticias de litigios peninsulares que requerían del concurso de personas que habían dado el pase a Indias. Uno de ellos

hacerlo. Se les da orden de hacerlo a contar desde el 18/12/1548. Francisco debería nombrar escribano para estar presente a la testificación. Lcdo. Hernán Bello. Dr. Covarrubias de Leyva. Lcdo. Becerra. Secretario, Gumiel (ARChG, expte. 5.726).

${ }^{80}$ 1543/04/10. Granada. Receptoria a las justicias de Lora y demás del Reino, a petición de doña Beatriz de Zúñiga, para que reciban información de ciertos testigos que estaban en Indias. Litigaban ante los oidores Arias Gutiérrez de Cervantes y doña Beatriz de Zúñiga, vecinos de Lora, sobre razón de ciertos bienes qu'el dicho Arias Gutiérez pide por virtud de una nuestra carta esecutoria, como patrón de cierta capellanía, llegada a la Audiencia por apelación de doña Beatriz, que se quejaba de que la justicia municipal le había denegado cierto cuarto plazo que había pedido para realizar su probanza en las Indias y en otros lugares fuera de estos Reinos. Ambas partes acudieron a la Chancillería, que retuvo el caso y mandó a la apelante que en 10 días diese información sobre los testigos que decía tener en Indias y otras partes fuera. Doña Beatriz pidió se le diese receptoria para ello, como se la dan. Lcdos. Diego de Deza, Arana y don Juan Sarmiento. Secretario, Mármol (ARChG, expte. 5.673).

${ }^{81} 1539 / 09 / 11$. Granada. Receptoria a las justicas de la ciudad de Santo Domingo, como del resto de los lugares de las Indias y Nueva España: pendía pleito ante los oidores entre Constanza Bernal, mujer de Jerónimo de Medias, vecina de Sanlúcar de Barramea, y Hernando de Rosas, también vecino, a cuenta de tutela y guarda de ciertos bienes que aquélla reclama a éste del tiempo que los tuvo a su cargo, con cuenta de los mismos. Llegada en apelación de cierta sentencia del juez del duque de Medina Sidonia, que concedió a Hernando plazo de año y medio para hacer su probanza en Ultramar; en vista y revista los oidores se declararon competentes y retuvieron el conocimiento de la causa; fueron recibidos a prueba sin plazo alguno, pero que, para que se siguiese la causa, no se viesen los autos en los seis meses siguientes, por auto de revista de 02/09/1539; luego, a petición del demandado, dan receptoria para la justicia, ante la que pueda presentar un máximo de 30 testigos, etc. Dr. Gálvez. Lcdos. Arrieta y Muñoz. Registrador, Lcdo. Juan Álvarez de Alarcón. Secretario, Medina (ARChG, expte. 5.645).

${ }_{82}$ 1545/01/21. Granada. Citatoria a Leonor López, mujer del bachiller Villafranca, y a Pedro Fernández Ramos, como curador y defensor de los bienes de Gonzalo Sayago, vecinos de la Fuente del Maestre, a petición del procurador de María Rodríguez Zambrana, viuda de Juan López Sayago, y consortes, vecinos de la Puebla de Sancho Pérez, que se había presentado en apelación de ciertos autos dados a favor de aquéllo y en contra de éstos por los alcaldes ordinarios de la Fuente del Maestre, que habían concedido 20 meses de plazo para realizar unas probanzas en las Indias en cierto pleito que trataban sobre ciertos bienes. Emplazados en 15 días. Dr. Gálvez. Peñaranda. Lcdo. Navia. Secretario, Meneses (ARChG, expte. 5.692). 
fue Diego Tornero, cuyos nietos solicitaban en 1541 de la Casa de la Contratación certificación de la fecha y nave en que aquél había pasado a América. ${ }^{83}$

Contamos, finalmente, con cuatro noticias de difícil encaje en los epígrafes que hemos diseñado: en ese mismo año 1541 sabemos que Cristóbal de Tavira, vecino de la ciudad de Cuba, había obtenido requisitoria para las justicias de esa ciudad contra dos sujetos a los que perseguía criminalmente. ${ }^{84}$ Unos pocos meses más tarde era Jerónimo López, vecino de la ciudad de Santo Domingo, quien apelaba de sentencia del teniente de gobernador del Campo de Calatrava, contra los herederos de dos vecinos de Almodóvar del Campo. ${ }^{85}$ Para 1550 disponemos de una curiosa inhibitoria para la justicia eclesiástica de Sevilla, concedida a petición del piloto Nicolao Nicardo — de probable ascendencia italiana-, morador en la villa de La Habana, que deseaba que su mujer, Juana Hernández, se trasladase a Cuba a hacer vida maridable con él. ${ }^{86}$ Un año más tarde hallamos a Juan de Ordu-

${ }^{83}$ 1541/09/06. Granada. Compulsoria a los jueces y oficiales residentes en la Casa de la Contratación de Sevilla, a petición de María de Espinosa y sus hermanos, vecinos de Granada, para que les dé traslado del día en que Diego Tornero pasó a Indias. María y sus hermanos litigaban ante la Audiencia con Juan Gaytán y consortes, también vecinos, y con Mencía de Santarem, como tercera opositora, sobre razón de ciertos bienes rayzes; María necesitaba un testimonio del día que Diego Tornero, agüelo de sus partes, pasó a las Yndias y en qué nao enbarcó. Lcdo. Hernán Bello. Dr. Peñaranda. Lcdo. don Juan Sarmiento. Escribano, Adarve (ARChG, expte. 5.662).

${ }^{84}$ 1541/01/00. Granada. Receptoria para las justicias de la ciudad de Cuba y demás del Reino y dos escribanos, a petición de Cristóbal de Tavira, vecino de la ciudad de Cuba, que como acusador litigaba en la Audiencia con Diego de Adejia y Juan Gatana, reos, en rebeldía, por causa no expresada. Fueron recibidos a prueba con plazo de 30 días, para la cual Cristóbal pidió requisitoria. Alcaldes del crimen, Lcdos. [Luzón], Angulo y Sacedo. Escribano, Nájera (ARChG, expte. 5.657).

${ }^{85} 1541 / 06 / 20$. Granada. Citatoria y compulsoria a los hijos y herederos de Blas Valderas y Juan Rodríguez de Villafranca, vecinos de Almodóvar del Campo, a petición de Jerónimo López, vecino de la ciudad de Santo Domingo, en las Indias, que apelaba de sentencia del bachiller Oviedo, teniente de gobernador del Campo de Calatrava, sin expresar causa. Emplazados en 15 días y compulsa en 6. Fernán Bello. Dres. Gálvez y Peñaranda. Escribano, Adarve (ARChG, expte. 5.661).

${ }^{86} 1550 / 02 / 14$. Granada. Mandamiento para que juez eclesiástico otorgue apelación, si fuere pedida en tiempo y forma, o envíe el proceso original en 15 días y absuelva durante 40 días, a petición de Nicolao Nicardo piloto, estante en Indias.

Al Dr. Juan de Escobar, [capiscol] y vicario general de la iglesia de Sevilla, y al Lcdo. Bravo, juez de apelaciones de la misma, a petición de Álvar Núñez, procurador de Nicolás Nicardo piloto, estante en la villa de La Habana, en las Indias, que expuso cómo había enviado con su poder a la ciudad de Sevilla para llevar a Juana Hernández, su mujer, a Juan Canelas, vecino de Sevilla en la collación de Santa Ana, e porque la susodicha se escusaba de yr con el dicho su parte a haser vida maridable en uno, como hera obligada, el dicho Juan Canelas avía parescido ante vos, el dicho doctor Escobar e pedido hos conpeliésedes a la parte contraria que fuese con el dicho su parte, como hera obligada, la qual avía pedido luego alimentos e para seguir el pleito sin aver por qué; el juez no sólo no la había compelido, sino que le había concedido alimentos; había suplicado de dicha sentencia ante el juez Bravo, que confirmó la anterior sentencia; apeló ante la Santa Sede, pero Bravo le denegó la apelación. Ambos jueces siguieron procediendo hasta embargar al dicho Juan Canelas todos los bienes e mercaderías que en una nao tenya, diziendo ser suyas del dicho su parte. Apeló de la fuerza y agravio cometido por los jueces eclesiásticos ante la justicia real.

Orden de conceder la apelación pedida, si hubiere lugar, de enviar el proceso original y de levantar la excomunión (sin incluir amenaza penal). 
ña, vecino de Sevilla, actuando contra los oficiales de la Casa de la Contratación y buen número de personas de alcurnia de la ciudad, pues, siendo hidalgo, habían ejecutado su domicilio y demás bienes, a instancias de Francisco de Arteaga y Domingo de Córdoba, si bien no se expresa el motivo exacto de la ejecución. ${ }^{87}$

\subsection{Procesos por la liberación de esclavos indios}

Desde los inicios del descubrimiento hasta entrado el reinado del Emperador Carlos (1542) se produjo un flujo constante de indios traídos a la Península en situación de esclavitud, a veces, directamente por colonos españoles, a veces a través del centro distribuidor del momento, Lisboa; como feria subordinada a dicho centro se hallaba la que se celebraba en Zafra a finales del mes de junio. Tenemos un testimonio de esta relación. ${ }^{88} \mathrm{Si}$ bien este flujo de esclavos tanto indios como negros se documenta con profusión en los protocolos notariales granadinos. ${ }^{89}$

Otrosy, por esta nuestra carta mandamos a la dicha Juana Hernández que del día que le fuere leyda hasta quynze días primeros syguientes paresca por sy o por su procurador suficiente con su poder bastante ante los dichos nuestro presidente e oydores en seguimiento del dicho pleito, a estar e ser presente a la vista e determinación d'él, con apercibimiento que le hazemos que, sy no paresciere, pasado el dicho término en su absencia e rebeldía, no enbargante, aviéndola por presente, lo verán e determinarán en ello lo que hallaren por justicia.

Lcdos. Girón, Covarrubias y Lope de León. Escribano, Nájera (ARChG, expte. 5.737).

${ }^{87}$ 1551/02/27. Granada. Citatoria a Francisco de Arteaga, Pedro Gómez de Arteaga, su hermano, Agustín de Santander, don Alonso Luis de Lugo, don Pedro Hernández de Lugo, su padre, don Álvaro de Fuente, su yerno, a los oficiales de la Casa de la Contratación de las Indias de la ciudad de Sevilla, el jurado Francisco Pérez, oficial que fue del contador Diego de Zárate, el jurado Pedro de Alcázar, Pedro de Cantillana, Pedro de Villasana, Cristóbal de Mújica, Antonio Beltrán y la mujer, hijos, hedereros y albaceas del Dr. Beltrán, para que asistan a un proceso, con apercibimiento de que las decisiones que en él se tomaren les afectarán como si hubiesen estado presentes, a petición de Martín de Orduña, vecino de Sevilla.

Orduña se había presentado ante los oidores afirmando ser hidalgo notorio de devengar 500 sueldos, a fuero de España, y de ello tenía carta ejecutoria, a pesar de lo cual, a petición de Francisco de Arteaga y de Domingo de Córdoba, se le había hecho ejecución en sus casas de morada, en las ropas y armas de su cuerpo y otros muchos bienes muebles y raíces, resultando despojados él, su mujer e hijos. Solicitaba restitución de casas, armas, cabalgaduras, ropas de su cuerpo, necesarias para su vida y sustento. El Presidente y oidores mandaron a las justicias de Sevilla que, si fuere hidalgo, le dejasen todo lo que la ley mandaba (23/12/1541).

Luego compareció Orduña y pidió copia de la anterior provisión, pues se le había perdido la misma; aprovechó para presentar una nueva petición, de que se dio parte al fiscal. Ahora pedía se diese también traslado a los encartados en el encabezamiento, para que no le parase perjuicio, emplazándolos también.

Emplazados en 15 días. Lcdo. Becerra. Dr. Covarrubias de Leyva. Lcdo. Oviedo. Secretario, Adarve (ARChG, expte. 5.755).

${ }^{88}$ 1538/09/20. Granada. Citatoria y compulsoria a Francisco Hernández, vecino de Granada, a petición de Juan Ruiz de Soria, procurador de Diego Hernández, vecino de Lisboa, que apelaba de sentencia del bachiller Juan González, alcalde mayor del condado de Zafra, sobre razón de un esclavo yndio. Emplazado en 15 días y compulsa en 4. Lcdos. Ramírez de Alarcón y Melchor de León. Dr. Peñaranda. Registrador, Lcdo. Juan Álvarez de Alarcón. Secretario, Mármol (ARChG, expte. 5.634).

${ }^{89}$ Se documenta un importante número de noticias en los protocolos de los años 30 y 40 del siglo XVI, en especial, a través de compraventas y quejas por vicios ocultos, que espero publicar en 
A pesar de haberse decretado en 1542 la liberación de los esclavos indios, lo cierto es que no pocos de ellos tuvieron que litigar por justicia para verse libres del yugo de las cadenas. Además, la liberación de los indios dio lugar, inevitablemente, a la incoación de procesos entre vendedor y comprador, al quedar éste burlado con dicha emancipación; tal ocurrió ese mismo año 1542 entre Pedro Mexía, vecino de Granada, y Francisco Fernández platero, vecino de Sevilla, a causa de la libertad alcanzada judicialmente por el indio Pedro. ${ }^{90}$ Una de las personas rezagadas a la hora de obtener su libertad fue la india María, estante en Granada, que litigaba para ello con Hernando Narváez de Ballesteros, de esa vecindad, la cual pidió compulsa de las provisiones recibidas por la Casa de la Contratación relativas al caso y de las actuaciones de un juez comisionado para la liberación de esclavos mexicanos. ${ }^{91}$

otro lugar; en cualquier caso, lo que queda claro de dichos documentos es la dependencia de Lisboa y Sevilla para el surtido de esclavos tanto africanos como americanos.

Como era habitual en la época, no fueron pocos los españoles que, teniendo o no una relación directa con América, acabaron tomando su apellido de aquellas tierras, como documentamos en 1551 en la persona de Fernán Sánchez de las Indias, vecino de Mérida (1551/09/03. Granada. Citatoria y compulsoria al concejo de Mérida y a Juan Martínez y Fernán Sánchez de las Indias, vecinos de la ciudad, a petición de Diego de Ocampo y Francisco López, también vecinos, que apelaban de sentencia del alcalde mayor de la ciudad por la qual avía mandado que no entrasen ny ronpiesen la dehesa y prado de la Cara. Emplazados en 15 días y compulsa en 3. Lcdos. don Juan Sarmiento, Oviedo y Frías. Secretario, Barahona. ARChG, expte. 5.762).

90 1542/02/27. Granada. Ejecutoria a petición de Pedro Mexía, vecino de Granada, contra Francisco Fernández platero, vecino de Sevilla, por el saneamiento por evicción por la venta de un indio. Se había celebrado pleito ante los oidores por nueva demanda entre Pedro Mexía, vecino de Granada, y Francisco Hernández platero, vecino de Sevilla, iniciado el 16/11/1540, cuando Mexía demandó al platero, pues le había vendido a Pedro indio en 23 ducados, y el indio había puesto demanda por su libertad en Granada ante el Lcdo. Luzón, alcalde del crimen, siendo dado por horro y su parte condenada en costas; apeló ante los oidores, que confirmaron la sentencia con costas, ejecutándose las sentencias contra su parte; que el indio Pedro era libre y el platero se lo había vendido por esclavo, no habiendo querido sanearle por evicción. Dan citatoria para el platero y lo tienen por caso de corte. Francisco pide se inhiba la Chancillería, pues era vecino de Sevilla. Mexía no alega nada; concluso. Dictan auto para que las partes acudan a primera audiencia a alegar en el negocio principal. Pedro se reafirma y Francisco no contesta. Pedro presenta probanza, no así Francisco. Sentencia de vista, condenado el platero a pagar en 9 días a Mexía los 23 ducados del precio, con los daños e intereses causados, con costas. Episcopus [abulensis]. Lcdo. Cereceda. Dr. Peñaranda (Granada, 22/11/1541). Notificada a los procuradores de ambas partes, no apelan, quedando en cosa juzgada. Mexía pide se le libre ejecutoria. Tasan las costas en 6.280 mrs. Rubrican el Dr. Peñaranda. Lcdo. Cereceda. Episcopus [abulensis]. Escribano, Adarve (ARChG, expte. 5.667).

${ }^{91}$ 1551/04/15. Granada. Compulsoria al escribano concernido, a petición de María india, estante en Granada, que litigaba ante los oidores con Hernando Narváez de Ballesteros, vecino de la ciudad, sobre razón de la libertad de la dicha María yndia, la cual expuso que por mandato de esa Audiencia había ido un juez de comisión a la ciudad de Sevilla a poner en libertad a todos los yndios de Santiago de México y otros yndios, en el qual avía hecho cierto auto e avían mandado dar ciertos pregones para que los dichos yndios llevasen ante parte poner en su libertad, todo lo qual con las provisiones por nos sobrello dadas están en la Casa de la Contratación de la dicha cibdad, e que por su parte tenya nescesidad dello para presentar en el dicho pleito, no pidió e suplicó le mandásemos dar nuestra carta para que le diésedes un traslado de todo en pública forma. 
El mismo buen fin que suponemos consiguió esta india sabemos positivamente que alcanzó ese mismo año el indio mexicano Melchor, de 20 años, que litigó su libertad con Pedro López peraile y Hernán Díaz tintorero, cesionario del anterior, vecinos de Córdoba. ${ }^{92}$ Un último testimonio de estos esfuerzos libertadores lo tenemos en 1552, cuando se dictó requisitoria a petición de los indios Lucas y Diego Hernández en pleito con la viuda e hijos de Pedro Rodríguez de la Mota, vecinos de Chillón. ${ }^{93}$

Compulsa en 3 días. La peticionaria debería pagar el traslado cuando viniere a mejor fortuna. Lcdos. Oviedo, Jaraba y Lope de León. Secretario, Medina (ARChG, expte. 5.756).

92 1551/10/10. Granada. Ejecutoria a petición de Melchor indio, vecino de México, contra Pedro López peraile y Hernán Díaz tintorero, cesionario del anterior, vecinos de Córdoba. A las justicias de Córdoba y del resto del Reino: se había tratado pleito ante los oidores entre los mencionados, pues en 16/09/1549 el indio compareció y expuso que siendo su parte honbre yngenuo y libre, la parte contraria de hecho le tenya por cautibo, que nos pedía y suplicava declarásemos a su parte por libre y condenásemos a la parte contraria a que le dexase gozar de su libertad y que le pagase lo que le avía servido, y qu'el conocimiento desta causa nos pertenecía por ser su parte pobre y ser sobre su libertad. Dada citatoria, comparece el peraile y niega la demanda: ésta estaba hecha con falsa relación, porque el dicho Melchor hera esclavo y por tal su parte le avía conprado de Andrés Sánchez, según constava y parescía por una escriptura de venta ..., porqu'el dicho Melchor no hera de las partes y lugares que dezía y que, [aunque] lo fuera, por ello no podya ser libre syno esclavo, según e como lo avía sido y hera.

Recibidos a prueba, presentaron sus probanzas, hasta concluir. En ese estado se presentó Hernando Díaz y exhibió ciertas escrituras y una petición, en que dixo que en la cárcel de la dicha nuestra Corthe y Chancillería estava pero el dicho Melchor, esclavo de color blanco, de hedad de veynte años, poco más o menos, el qual pertenecía a su parte, como parescía por las dichas escripturas, pidiendo se le entregase el esclavo para usar de él, como habían hecho sus cesionarios y él mismo antes de que huyese y se ausentase, que estaba presto a constituir fianzas de no trasportalle ny vendelle ny hazelle maltratamyento. Se le dio traslado a Melchor y concluyeron.

Sentencia de vista: Melchor había probado y sus contrarios no, por lo que le declaraban ser libre, pudiendo disponer de su persona y bienes y condenaban a éstos a respetar su libertad. Sin costas. Lcdos. Frías, Castilla y don Juan Sarmiento (Granada, 09/04/1550).

Sentencia de revista: Confirmada la de vista. Sin costas. Lcdos. Frías, don Juan Sarmiento y Ramírez de Alarcón (Granada, 07/07/1551).

El indio pide ejecutoria. Lcdos. Frías, Ramírez de Alarcón y don Juan Sarmiento. Secretario, Escobedo (ARChG, expte. 5.764).

${ }^{93} 1552 / 05 / 17$. Granada. Requisitoria a los dos escribanos que fueren puestos por las partes: pendía pleito ante los oidores entre los indios Lucas Hernández y Diego Hernández, de un lado, y, de otro, la mujer e hijos de Pedro Rodríguez de la Mota, vecinos de Chillón, sobre razón de la libertad de los dichos yndios. Fueron recibidos a prueba en plazo de 80 días. Ahora los indios habían solicitado requisitoria para hacer sus probanzas y compulsoria para que las partes contrarias exhibiesen el testamento de Pedro Rodríguez de la Mota, marido y padre de sus contrarios, así como el despacho que el difunto avía traído de las Yndias para pasar a sus partes a España.

Orden de hacer las probanzas, si fueran requeridos por los demandantes, en dicho plazo, a contar desde el 10 de mayo pasado, tomando declaración a un máximo de 30 testigos, sin les llevar derechos por ello, por quanto litigan sobre su libertad. El día antes de comenzar la probanza deberían dar parte a los contrarios para que nombren otro escribano que esté presente al examen de los testigos. Si los indios así lo pidieren, que compela a la parte contraria a que jure de calumnia las posiciones que ellos presentaren. Orden al corregidor, alcalde mayor o teniente de Chillón que compela a la parte demandada a exhibir el testamento y el despacho mencionados por los indios, sacando 


\subsection{Proceso por la liberación del súbdito del Preste Juan}

Los portugueses a lo largo de su periplo por las costas africanas en los años finales del siglo XV y comienzos del siguiente transportaron a la Península Ibérica gran número de personas esclavizadas en los distintos puntos en que tocaban puerto. La antigua Abisinia no fue ajena a las depredaciones lusas, como nos muestra el proceso conservado en la Chancillería granadina, promovido por Cristóbal de Perea, cristiano que se decía súbdito del Preste Juan de las Indias.

Dicho proceso tuvo lugar entre 1536 y 1539; en el primero de esos años el esclavo cristiano presentó demanda por su libertad contra los hermanos sevillanos Luis Álvarez y Gómez Hurtado mercaderes:

Citatoria a Luis Álvarez mercader y a Gómez Hurtado, vecinos de Sevilla, a petición de Antón Pérez, procurador de Cristóbal, cristiano natural de la Tierra del Preste Juan de las Indias, que presenta demanda: su parte hera libre, hijo de padres libres, cristianos naturales de las Yndias del Preste Juan, y que, syendo el dicho Christóval, su parte, persona libre, cristiano, no sujecto a servidunbre ny cativerio alguno, porque, siendo de las dichas Yndias del Preste Juan y cristiano, no pudo ser cativo de cristiano, y que vos, los susodichos, de poco tienpo a esta parte vos jatávades y alabávades que su parte hera vuestro esclavo y que como de tal vos avíades de servir d'él, syendo como hera libre y cristiano de la dicha Tierra e nación, como costava y parece por su aspecto y por las señales del santo Bautismo que traya en la frente, hechas con fuego ardiendo, como se acostunbrava en la dicha Tierra del Preste Juan.

Por ende, que nos pedían y suplicavan vos condenásemos a que de aquí adelante no vos jactásedes y alabásedes de lo susodicho e vos disistieses dello y dezir que su parte hera vuestro esclavo, declarando al dicho su parte por persona libre y horro de toda servidunbre y cativerio, pues lo hera, haziendo a su parte entero cunplimiento de justicia, condenándolos, así mismo, en la soldada que a su parte se debe del tienpo que vos avía servido...

Otrosí, dixo qu'el conocimiento desta cabsa pertenecía a nos, por ser el dicho su parte pobre y por tal estava mandado ayudar en la dicha nuestra Abdiencia.

El Presidente y oidores lo tuvieron por caso de Corte. Emplazados en 12 días.

Otrosí, nos fue pedido e suplicado por parte del dicho Cristóval que porque su parte hera pobre e vos, los susodichos, personas faborecidas, le mandásemos dar nuestra carta de seguro real, para que por razón de se aver venydo a quexar de vos no le prendiésedes ni hiziésedes nyngún mal tratamiento y le dexásedes seguyr su pleyto sin ynpedimyento alguno.

El Presidente y oidores lo ponen bajo su guarda, seguro, amparo y defendimiento real y lo aseguran frente a los demandados, sus parientes, criados, amigos y valedores, a los que prohiben prenderlo, matarlo ni lisiarlo ni consientan ni manden que sea prendido, muerto, herido ni lisiado o causarle otro mal ni daño en su persona contra razón e de derecho e como no deváys, so pena de la merced real y de 100.000 mrs. para la cámara, además de incurrir en las penas previstas para los que quebrantan treguas y seguros reales. Mandan al Asistente de Sevilla o a su teniente y demás justicias del Reino que procedan contra ellos, si no lo observasen. ${ }^{94}$

traslado de los mismos, sin derechos. Lcdos. Arana, Huarte y Salas. Secretario, Barahona (ARChG, expte. 5.773).

${ }_{94}$ 1536/03/14. Granada. Enplazamiento por nueva demanda e caso de Corte y seguro para la persona, en forma, a pedimiento de Cristóval, cristiano natural de la Tierra del Preste Juan de las 
Tres años se demoraría la causa, en la que el demandante conseguiría su objetivo de obtener su libertad, lo que sabemos merced a la conservación de la correspondiente ejecutoria. No deja de ser curiosa, sin embargo, la argumentación de los mercaderes sobre la no cristiandad de su hombre, pero, en cualquier caso, nos informa de algo cierto: fue traído del África portuguesa hasta Madeira y desde ahí a Lisboa, desde donde acabó recalando en Sevilla.

A las justicias de Sevilla y demás del Reino: se había tratado pleito ante el presidente y oidores por nueva demanda entre Cristóbal, de color loro, natural de la Tierra del Preste Juan de las Yndias, y Luis Álvarez mercader y Gómez Hurtado, su hermano, vecinos de Sevilla, iniciado por Cristóbal, que presentó demanda contra los hermanos mercaderes, diciendo ser libre e hijo de padres libres, cristiano, procedente de las Indias del Preste Juan, por lo que no podía ser cautivo de cristianos.

Se le dio citatoria y los demandados comparecieron y presentaron escrito de excepciones: que el demandante había hecho mala relación, que era esclavo, siervo y cautivo suyo, de lo que tenían títulos en Sevilla, en Lisboa y en la isla de Madeira, y en todo el dicho tienpo nunca avía dicho ny pedido lo que al presente pidía. Lo otro porqu'el dicho Christóval no hera natural de la Tierra que dezía, antes hera de la Yndia de Portugal, de una generación que se llamava los abexines, los quales heran ynfieles de su naturaleza e continuamente tenían guerra con christianos, especialmente, con portugueses, los quales avían cativado muchos dellos y los avian vendido como a esclavos por lo ser, e que asy de la dicha manera avía sydo caytuvo el dicho Christóval e llevado a la cibdad de Lisboa, donde avía servido mucho tienpo, e después avía sydo llevado a la dicha Ysla de Madera, donde los dichos sus partes le avían abido. Lo otro porque sienpre, después qu'el dicho Christóval hera cativo asy en poder de los dichos sus partes como de otras personas, que antes lo avían tenydo continuamente, el dicho Christóval comunycava e tratava con moros e ynfieles y fablava arávigo. $Y$ que, viendo lo susodicho, los dichos sus partes y queriéndose ynformar e saber sy hera christiano, porque no le veyan fazer obras de christiano, antes de ynfiel e muchos dezían que no hera christiano, porque [no] sabía el paternoster ni el avemaría ny otras oraciones que como christiano hera obligado a saber, por fuerça e ynportunydad e açotes que sobrello le dieron se las hizieron deprender después qu'estava en su poder. ${ }^{95}$

Yndias. Lcdos. Arrieta y Muñoz. Dr. Gálvez. Registrador, Lcdo. Juan Álvarez de Alarcón. Secretario, Juan Moreno (ARChG, expte. 5.600). Gratis, por pobre.

Aún en la actualidad es costumbre entre los etíopes tatuarse la cruz en la frente.

95 1539/04/18. Granada. Ejecutoria a petición de Cristóbal de Perea, natural de la Tierra del Preste Juan de las Indias.

Sentencia de vista: Cristóbal probó su intención y los mercaderes no sus excepciones, por lo que le declaran a Cristóbal persona horra y libre de toda sujeción, cautiverio y servidumbre, por lo que podía estar y andar por donde le pareciere, disponiendo de su persona y bienes. Anulan cualquier compraventa que se hubiera realizado de su persona. Que los demandados no molesten a Cristóbal en nada relativo a su libertad, so pena de 70.000 mrs. para la cámara. Dan por libre al fiador o depositario que éste hubiera designado en el proceso. Lcdos. Melchor de León, Peralta y don Juan de Castilla (Granada, 21/05/1538).

Sentencia de revista: Confirmatoria de la de vista en todos sus extremos. Episcopus tudensis. Lcdos. Muñoz y Melchor de León (Granada, 29/03/1539).

A petición de Cristóbal se libra ejecutoria. Su señoría y Dr. Peñas. Lcdo. Melchor de León. Registrador, Lcdo. Juan Álvarez de Alarcón. Escribano, Juan Moreno (ARChG, expte. 5.642). Sin derechos. 


\section{Conclusiones}

A lo largo de las páginas que preceden, en las que he intentado exponer de forma ordenada las noticias que se conservan en los años mencionados sobre el mundo americano y su inevitable correlato peninsular, se ha podido apreciar meridianamente una de las caras de la conquista de América a cuenta de la Corona española, la de la codicia por los metales preciosos, que forma junto con la evangelización del indio, el anverso y reverso de la misma moneda.

Desde luego hay que reconocer que la documentación de origen judicial, casi necesariamente contenciosa, no presenta el aspecto más hermoso de la condición humana, más bien el contrario, por ello no es extraño que la impresión que se saca de los datos que hemos expuesto sea la de unos sujetos ávidos por enriquecerse con el menor esfuerzo y la mayor rapidez posibles. Los intentos, muchas veces patéticos, de los transportistas del oro y plata desde América a la península de quedarse con la mayor parte posible e, incluso, con todo el capital, indican esta ciega atracción que seducía al hombre de la época $-\mathrm{y}$ me temo que en esto poco ha cambiado la humanidad-. No siempre los documentos son lo suficientemente expresivos de esto, pero, salvo excepciones, todo parece recorrer un mismo camino: las dificultades de traer los metales preciosos a España y, con esto como excusa, las triquiñuelas que mandatarios, transportistas y emisarios utilizaron para quedarse con el objeto de su deseo.

Para poner un botón final a lo dicho contamos con un proceso que tuvo lugar en torno a 1542 entre Mari Sánchez la Gorda y su marido, Cristóbal Martín, ambos de linaje de labradores y vecinos de la aldea de La Zarza de Montánchez. ${ }^{96}$ Como se podrá apreciar en seguida, la realidad siempre supera a la ficción, por cuanto estamos en presencia de un perfecto guion de novela negra. En efecto, alrededor de 1530 Cristóbal hubo de huir de su lugar de residencia, dejando abandonada a su mujer, luego de haber mantenido relaciones íntimas con su cuñada, viuda de su difunto hermano. Según el letrado que redactó el documento de denuncia, el Dr. Juan Gil, había cometido con ello tanto adulterio como incesto.

Aunque no se diga expresamente, es más que probable que Cristóbal en sus andanzas por el Perú debió de formar parte de las tropas que acompañaron a los Pizarro en su conquista. Es el hecho que en 1542 había retornado a su localidad de origen, con 30.000 ducados en la bolsa y una mentalidad totalmente diferente a la

${ }^{96} 1542 / 04 / 01$. Valladolid. Incitativa al corregidor de Mérida o a su teniente, a petición de Mari Sánchez la Gorda, mujer de Cristóbal Martín, vecina de la Zarza de Montánchez, que solicitaba el envío de juez pesquisidor contra su marido y demás personas implicadas, que parescen aver sydo culpados en le aver mandado dar ciertos polvos venenosos y en otros delitos.

Conde. Luján. Sarmiento. Anaya. Arteaga. Secretario, Guerrero (AHT, expte. 78.304).

Acompañan escrito de querella (apéndice II) y poder: el 22/03/1542, estando Mari presa en la cárcel pública de Montánchez, otorga poder a su cuñado Juan Martín, vecino de Salvatierra, y a Serván Domínguez, vecino de Mérida, para seguir la causa contra su marido, sobre que me quyso matar con cierta ponçoña e polvos e de otra manera. 
que se había llevado de España. Como denunció su mujer, se jactaba públicamente de que con ese capital se había vuelto intocable para la justicia. De hecho, había comprado a los pudientes de su aldea, de Montánchez y hasta de Mérida, gracias a los préstamos que les tenía hechos. Incluso, había llegado a firmar una escritura secreta de esponsales con la hija de un hidalgo de Trujillo para cuando falleciese su mujer.

Como no era cosa de esperar mucho, Cristóbal decidió deshacerse de Mari a la primera oportunidad. Para ello hizo que los alcaldes ordinarios de Montánchez acusasen y procesasen a su mujer, diciendo que había cometido adulterio con un paisano en ausencia de su marido, algo que la esposa negaba con indudable vehemencia. Para mejor alcanzar sus fines, Cristóbal hizo que la justicia pusiese a su mujer a cuestión de tormento y sobornó al verdugo para que le apretase tanto los cordeles, con los correspondientes garrotes, que le produjese la muerte, además, por si eso fallaba, hizo introducir en la cárcel con el negro Gonzalo una pócima hecha con solimán y rejalgar — polvos de mercurio, azufre y arsénico- para que le fuese administrada mientras recibía el tormento del agua. En ambos intentos falló el supuesto asesino, ya que la mujer fue advertida a tiempo de sus intenciones y recusó al verdugo e hizo detener al esclavo negro.

Visto que la mujer no podía confiar en la justicia de su entorno, acabó solicitando que se remitiese juez pesquisidor, que viera tanto la falsa causa que se le seguía a ella por adulterio, como los intentos de asesinato que había ideado su marido. Fue determinante para esa petición que la sola persona que se atrevió a procurar por ella — el resto de sus parientes no quiso ayudarla, pues estaban amenazados por su marido - sufriera una emboscada cuando intentó salir rumbo a la Corte para denunciar este estado de cosas; por fortuna para el procurador supo del embeleco y pudo escapar a la muerte.

No deja de ser sintomático que el letrado de la mujer añadiera en su petición de pesquisidor que tenía por seguro que Cristóbal sabría por boca de los alcaldes ordinarios el letrado al que mandarían a sentenciar la causa y, en consecuencia, lo sobornaría para que le impusiese la pena mayor posible.

Lo cierto es que el Consejo de Órdenes no vio tanta gravedad en el caso como para enviar un juez pesquisidor, sino que decidió encomendar la causa al corregidor de la ciudad de Mérida. ${ }^{97}$

\footnotetext{
${ }^{97}$ Realmente, el envío de juez pesquisidor se reservaba, habitualmente, para casos de asesinato o de alteración grave del orden público, aunque hubo excepciones.

Recibida la incitativa para el corregidor, Mari decidió reclamar ante éste la atribución de la mitad de la fortuna traída por su marido del Perú, como bienes gananciales, a fin de que se depositaran en persona apropiada y pudiese usarla en la prosecución de su proceso criminal. Decía así la demanda presentada por la mujer en Mérida, el 27 de abril de 1542:
}

Muy noble señor

Mari Sánchez, muger de Christóval Martín, vezinos de la Çarça de Montanches, parezco ante v.m. como juez delegado de S.M. por virtud de la comisión que ante v.m. de S.M. tengo presentada sobre los delitos que me acusa el dicho mi marido e yo le acuso sobre lo a ellos anexo e dependiente, e pon- 
Así pues, la posesión del oro excitaba de tal modo a sus dueños que deseaban cambiar de forma de vida de modo radical, en unos casos — como el que acabo de comentar- mediante la eliminación de la mujer y la contracción de un vínculo matrimonial más prometedor, y, en otros, con la exhibición descarnada del propio poder, procedente de la posesión del oro importado de Indias. Esto es lo que había ocurrido años antes en Segura de León, cuando Juan de Bazán y Diego Mexía, retornados enriquecidos de Indias, se hacían acompañanar de rufianes, esclavos negros y otros sujetos peligrosos, con la finalidad de hacerse reconocer una preeminencia social que no les correspondía por su nacimiento y estatus. ${ }^{98}$

go ación e demanda al dicho Christóval Martí, my marido, quynze myll ducados, e contando el caso digo que puede aver treze años o poco más o menos que fue a las Yndias del Perú e constante el matrimonio entre my y el susodicho, a ganado e adquerido treynta myll ducados, de los quales me pertenecen los quynze e dellos soy verdadera señora por ser adqueridos durante el dicho matrimonyo.

A v.m. pido que, avida esta my relación por verdadera o la parte que della bastante para prueva de my yntinción condene al dicho Christóval Martín, my marido, a que me dé y entregue los dichos quynze myll ducados e aquéllos le mande luego deposytar en poder de una buena persona, lega, llana e abonada, para que dellos gaste lo que fuere necesario en los dichos pleytos, para lo qual el oficio de v.m. ymploro e pido justicia e costas.

El dotor Juan Gil.

La parte que se conserva de este proceso civil indica que Cristóbal impidió que siguiera adelante normalmente, alegando que el corregidor carecía de jurisdicción, ya que la comisión recibida del Consejo no le permitía ejercitarla en este caso; tras apelar de la decisión del teniente de corregidor de declararse competente, la causa llegó ante el Consejo, pero no sabemos si continuó allí, si siguió procediéndose en Mérida, a despecho de dicha apelación, o si quedó finalmente paralizada (AHT, expte. 16.771). Sobre la causa criminal, instada previamente, sabemos que estaba vista para sentencia a fines del mes de julio, cuando compareció Cristóbal ante el Consejo y solicitó que el corregidor, el caballero Hernandálvarez de Meneses, fallase la causa, pues estaba conclusa; para ello se le dio la provisión acostumbrada, según la ley (AHT, expte. 78.307).

98 1536/03/18. Madrid. Incitativa a Francisco de Luzón, caballero de la Orden y corregidor de Jerez de los Caballeros, o a su teniente, el Lcdo. Noguerol: de poco tienpo acá han venido de las Yndias a la villa de Segura de la encomienda mayor, Juan de Baçán e Diego Mexía, los quales diz que moran en ella, e que por aver traydo muchos dineros, andan acompañados de rufianes e negros e honbres escandalosos, e que asy trayéndolos consigo, como apartados, armados y en quadrilla, han causado en la dicha villa muchas quystiones y escándalos no acostunbrados en ella, desacatando e menospreciando a la justicia de la dicha villa e al alcaide della, metiendo sillas de caderas en la capilla de la yglesia parrochial de la dicha villa y metiendo a sus mugeres a que se asienten en la dicha capilla, haziendo que se prefieran a todas las del pueblo, como si fuesen señoras d'él, lo qual diz que antes de lo susodicho no se ha fecho por personas de calidad ... e que en la carnicería e pescadería della quieren ser preferidos, enbiando a los dichos sus honbres e criados a que tomen la mejor carne e pescado e primero que la justicia e qu'el dicho alcaide, e que sobrello han hecho amenazas he dicho muchas palabras feas e ynjuriosas, e tomado la dicha carne e pescado syn que se pese, contra voluntad de los vendedores; e qu'el dicho Juan de Baçán tiene a uno, que se dize Alonso de Miranda, rufián público, que trae consigo una muger del partido, ganando con ella dineros, etc.

El clavero. Luján. Sarmiento. Anaya. Álava. Secretario, Guerrero (AHT, expte. 78.231). 


\title{
APÉNDICE I
}

\author{
1552/00/00. Granada
}

Executoria a pedimiento de Pedro de Barrantes, vezino de la ciudad de Trugillo.

Secretario, Adarve.

Registro .IX.

Archivo de la Real Chancillería de Granada, expte. 5.786. Ejecutoria en 10 pliegos.

Don Carlos, etc. a todos los corregidores, asistentes, governadores, alcaldes mayores y ordinarios y otros qualesquier juezes o justicias qualesquier, asy de la cibdad de Trugillo como de todas las otras cibdades, villas y lugares de los nuestros Reynos e señoríos e a cada uno y qualquier de vos en vuestros lugares y jurisdiciones, a quien esta nuestra carta executoria fuere mostrada o su traslado sygnado de escrivano público, sacado con autoridad de juez o alcalde en manera que haga fee. Salud e gracia.

Sepades que pleito pasó y se trató en la nuestra Corte y Chancillería ant'el presidente y oydores de la nuestra Audiencia, que resyde en la cibdad de Granada, entre Pedro Barrantes, vezino y regidor de la cibdad de Trugillo, y Antón Moyano, su procurador en su nonbre, de la una parte, y Fernando Piçarro e Ynés de Aguilar, vezinos de la dicha cibdad de Trugillo, y Francisca Rodríguez, moradora en el lugar de La Çarça, juridición de la dicha cibdad de Trugillo, herederos e hijos de Gonçalo Piçarro, su padre, difunto, y hermanos de don Francisco Piçarro e Juan Piçarro y de Gonçalo Piçarro, difuntos, en su ausencia e rebeldía, de la otra, el qual dicho pleito se siguió y trató en la dicha nuestra Audiencia ante los dichos nuestro presidente y oydores sobre razón de trezientas y veynte e un myll y ciento y ochenta y siete mrs., de que fue puesta demanda de dicho Pero Barrantes por parte del dicho governador Francisco Piçarro del decrecimiento que obo en el oro e plata que traxo del Perú, sobre lo qual se dio nuestra carta executoria a la parte del dicho Francisco Piçarro contra el dicho Pero Barrantes, librada del presidente y oydores de la dicha nuestra Audiencia, su tenor de la qual es este que se sigue:

[inserta la ejecutoria de 11/04/1538]

Con la qual dicha executoria, en veynte y cinco días del mes de abril del año pasado de myll e quynientos y treynta y ocho años, la parte de Ynés Rodríguez de Aguilar, en nonbre del dicho governador Francisco Piçarro, requirió al dicho Pero Barrantes en su persona que la guard[as]e e cunpliese, como en ella se contiene, y en dos días del mes de mayo del dicho año Francisco Sánchez, en nonbre del dicho Pero Barrantes, respondiendo a la dicha carta executoria y en cunplimiento della, requirió a la dicha Leonor de Aguilar, qu'estava presente, que de parte del dicho governador cunpliese la dicha executoria y, ésta cunpliendo, bolbiese al dicho Pero Barrantes el dicho juro e la certificación, como se mandava por la dicha executoria, qu'estava presto de lo recebir con lo corrido, e que cunpliendo ella de su parte le requirió que rescibiese de presente las dichas .ccc. e .ximdcccexcvii. mrs., de los quales hizo presentación en ducados de oro, como dello da fee el escrivano de la causa, e protestó que, no cunpliendo ella de su parte, fue[se] culpa suya y del dicho governador, su hermano, y que en el entretanto que no cunpla con el dicho su parte, no fuese visto ser en mora suya, syno de la parte contraria.

A lo qual respondió la dicha Leonor Rodrigues de Aguilar y dixo que hasta oy el dicho governador y ella, en su nonbre, no avían recibido juros algunos de los .xm. castellanos qu'el dicho Pero Barrantes avía traydo y Nos nos quesimos serbir dellos para los dar en juros y así no le tenya que tomar en quenta ny menos avía recibido certificación dellos, y, si alguna certificación se avía sacado, ésta estava en poder del fattor de Pero Barrantes, que se llamaba Hermosylla, e que asy ella no tenya los dichos juros ny los corridos dellos, en la dicha certificación, pues la parte contraria avía dicho que la tenía, e que por más le conbencer, qu'ella, en nonbre del dicho governador, e por virtud de los poderes que d'él tenía, desde luego renunciaba en el dicho Pero Barrantes y le bolbía los juros que le pertenecían y cabían y podía aver por razón de lo que por la dicha carta executoria y sentencias le estaba mandado dar, syn lo que tocava al porte, y que, si hera necesario, pedía e suplicava a los que resyden en la Casa de la Contratación que diesen al dicho Pero Barrantes certificación del 
juro que en ello montava y para que le fuese acudido con él, conforme a la dicha executoria, y se descontase de la certificación qu'el dicho Pero Barrantes avía dexado para que se diese al dicho governador, su hermano, para que le fuese acudido con ello con lo corrido, e requirió al escrivano de la causa que diese al dicho Pero Barrantes el traslado de la dicha executoria con la renunciación qu'ella hazía por virtud de los poderes, con el traslado dellos, que dixo estar en poder del escrivano de la causa, que sy heran necesarios para los cobrar y sacar el dicho previllegio, e por rata lo corrido del dicho juro, le traspasaba las abciones y le dava poder en causa propia para que los oviese para sy e protestó que, no pagando dentro de nueve días contenidos en la executoria, la quenta en ella contenida, asy de lo que tocava a los juros como de los .xlvi. qu'él avía detenydo e detenya, que lo cobraría todo por vía executiba, syn enbargo del que dezía depósyto o magnyfestación, pues que de derecho el que deposytava e no pagaba, no cumplía el efetto de la executoria, y esto dava por su respuesta, no consyntiendo e las peticiones en contrario fechas.

Y la susodicha hizo otro requerimiento al dicho Pero Barrantes cerca de lo susodicho, a los quales el dicho Pero Barrantes respondió, entre otras razones, dixo que la parte contraria no cumplía con la relación que le hazía, ny él hera contento con ella, salbo con lo que manda la dicha executoria, y que aquello se avía de cumplir, y que todavía requería a la susodicha que asy lo cumpliese y que le protestava que si diese de executar que fuese a su culpa y cargo y no a la suya.

Después de lo qual, en la dicha cibdad de Trugillo, en quatro días del mes de mayo del dicho año de myll y quinientos e .xxxviii. años, la dicha Leonor Rodrigues de Aguilar, en el dicho nonbre, por virtud de la dicha executoria, pidió execución en bienes del dicho Pero de Barrantes por las .ccc. y .ximdcccc. y .xcvii. mrs.. con ciertas protestaciones e juró en nonbre del dicho governador, su parte, serle devidos e no pagados.

E por el dicho Sancho Díaz, teniente de corregidor susodicho, fue mandado haser la dicha execución e mandó dar su mandamiento executorio contra el dicho Pero Barrantes por la dicha contía, el qual se dio en forma; por virtud del qual Diego de Mendoça, alguasil mayor de la dicha cibdad, hizo execución por bienes del dicho Pero Barrantes en un majuelo qu'él susodicho le nonbró en la Sierra del Erguijuelo, linde con majuelo de Gonçalo de Sanabria, y dio por fiador de saneamiento a Rodrigo de Cerbantes, vezino de la dicha cibdad, el qual se obligó que será cierto y sano y seguro y valdría la quantía al tienpo del remate, y se obligó en forma. Y el dicho Pero Barrantes dio los pregones por dados.

Después de lo qual, en seys días del dicho mes de mayo del dicho año, el dicho Pero Barrantes presentó un escripto, por el qual alegó largamente ciertas razones contra el dicho mandamiento de execución y execución y contra todo lo que es fecho y executado por la dicha justicia, lo qual todo pidió ser revocado o dado por nynguno, porqu'él no hera obligado a pagar cosa nynguna de la dicha quantía hasta tanto que se cumpliese con él lo contenido en la dicha executoria, especialmente, aviendo fecho las diligencias que tiene fechas y que en le mandar executar, como se le avía fecho, syn aver cumplido con él, se le avía fecho notorio agravio, de todo lo qual apelaba para ante los dichos nuestro presydente y oydores, e pidió que por ello lo rebocase.

Del qual dicho escripto el dicho juez mandó dar traslado a la otra parte, y por parte del dicho governador Francisco Piçarro fue pedido que, sin enbargo de lo de contrario dicho, procediese por la dicha execución adelante hasta le ser pagado de los mrs. por que pidió execución y costas.

Después de lo qual la parte del dicho Pero Barrantes presentó ant'el dicho juez una nuestra carta compulsoria, para que constase de cómo estava presente en la dicha nuestra Audiencia en grado de apelación sobre el dicho pleito.

Después de lo qual, en la dicha cibdad de Trugillo, en .xviii. días del mes de junyo del dicho año de myll y quinyentos e .xxxviii. años, ant'el licenciado Monleón, tenyente de corregidor en la dicha cibdad, pareció el dicho Francisco Sánchez, en nonbre del dicho Pero Barrantes, con protestación que hizo de no le atrebuyr más jurisdición de la que en este caso de derecho avía lugar, la qual protestava que fuese visto haser en qualquier auto tácito y expreso que por su parte le fuese fecho, e, afirmándose en la apelación por su parte ynterpuesta se oponya contra una execución en bienes de su parte, fecha a pedimyento de Ynés Rodríguez de Aguilar, vezina de la dicha cibdad, por quantía de .ccc. e .ximdcccc. y .xcvii. mrs., contra la qual dicha execución dixo y alegó ciertas causas y razones y pidió que se pronunciase por no juez de la causa, atento que pendía ante los dichos mi presidente y oydores, y porque la dicha Ynés Rodrigues de Aguilar no avía sydo parte para pedir la 
dicha execución, atento el tenor de la dicha executoria, e que, aunque lo fuera, caso negado, no se podía mandar haser la dicha execución en bienes de su parte ny de otra manera alguna hasta que la parte del dicho governador obiera conplido con efeto lo contenido en la dicha executoria, por lo qual e por otras causas y razones que dixo y alegó por el dicho escripto de apelación pidió se rebocase y diese por nynguna la dicha execución y a el dicho su parte y a sus bienes por libre della, con las protestaciones que tenya fechas e juró la dicha apelación en forma.

A la qual dicha apelación fue respondido por parte del dicho governador e pidió que, sin enbargo de lo en ella contenido, se hiziese pago a su parte de principal y costas. E parece qu'el dicho Pero Barrantes fue citado para el remate e por su parte fue puesta sospecha en el dicho teniente de corregidor, el qual tomó por acompañado a Pero de Monleón, el qual hizo la solenydad del juramento necesario, e visto por el dicho licenciado Diego de Monleón, teniente de corregidor susodicho, e Pero de Monleón, su acompañado, dieron e pronunciaron en el dicho pleito sentencia de revista, su tenor de la qual es este que se sigue:

«Visto por nos, el licenciado Monleón, teniente de corregidor en esta ciudad de Trugillo, e Pero de Monleón, su aconpañado, este proceso de execución, qu'es entre el comendador Francisco Piçarro, gobernador en las Yslas del Perú, e su procurador en su nonbre, parte que pidió la dicha execución, e Pero de Barrantes, vezino desta dicha ciudad, e su procurador en su nonbre, parte que defiende e contra quien se pide, vista la executoria de S.M., por donde la dicha execución se pide e las sentencias en ella ynsertas, vista la opusición del dicho Pero Barrantes e los requerimientos de una parte a la otra fechos, contentos que por las escrituras en esta causa presentadas, abtoriçadas de mano de Diego de Ayora, escrivano de Sevilla, pareze e costa que Rodrigo de Hermosylla, procurador del dicho Pero de Barrantes, tiene recibida en su poder la certificación que de parte del dicho Francisco Piçarro se abía de bolber al dicho Pero Barrantes, conforme a la dicha executoria, la qual recibió original con poder especial del dicho Pero Barrantes de Francisco de Çabala, fator del dicho comendador Francisco Piçarro. Visto e considerado todo lo demás procesado a que nos referimos, fallamos que debemos mandar e mandamos efetuar la dicha execución e hazer trance y remate de los bienes executados de el dicho Pero Barrantes en pública almoneda en la persona que más por ellos diere, e de los mrs. por que se bendieren hazer entero pago a la parte del dicho Francisco Piçarro de las dichas trezientas e honze myll e nobecientos e nobenta e syete mrs., que en la dicha executoria se le mandan restituyr, dando primeramente la parte del dicho Francisco Piçarro fianças abonadas que se obliguen conforme a la ley de Toledo, e porqu'el dicho Pero Barrantes a litigado sin causa e como no debía, le condenamos en las costas desta causa, cuya tasación reserbamos en nosotros. E así lo juzgamos por esta nuestra sentencia.

El licenciado Monleón. Pedro de Monleón. El licenciado Calderón».

La qual el dicho teniente de corregidor y acompañado dieron y pronunciaron en la dicha cibdad de Trugillo, en doze días del mes de jullio de myll y quinyentos y .xxxviii. años, estando en audiencia pública, y, en cumplimiento della, en este dicho día, mes y año susodicho Bicente Enríquez y Diego de Camargo, vezinos de la dicha cibdad, ambos a dos juntamente de mancomún, a boz de uno y cada uno por sí, se obligaron que, si la dicha sentencia de revista fuese revocada, qu'ellos y cada uno dellos bolberían la quantía del principal y costas, conforme a la ley de Toledo que sobr'el caso dispone, e para ello obligaron sus personas y bienes y de sus herederos e dieron poder a las justicias para que así se lo hiziesen tener, guardar, cumplir e pagar, e renunciaron las leyes de que en este caso se pudiesen aprobechar, asy en general como en especial, y la ley e derecho en que dize que general renunciación fecha non vala, y otorgaron carta de obligación en forma.

Después de lo qual el dicho majuelo, en que asy fue fecha la dicha execución, fue traydo en almoneda y se dieron ciertos pregones y andando en almoneda Juan Bicioso lo puso en diez myll mrs. y se le remató en ellos de último remate, el qual paresce que lo traspasó en la dicha Leonor Rodríguez de Aguilar y le cedió el derecho que en el dicho majuelo tenía, por parte de la qual fue pedido mandamiento para prender al dicho fiador y al dicho Pero de Barrantes, como principal.

Y paresce que en el dicho día, mes y año susodichos fue notificada la dicha sentencia al dicho Pero de Barrantes, por parte del qual fue apelado della para ante los dichos nuestro presidente y oydores. 
Y paresce que la dicha Leonor Rodríguez de Aguilar traspasó al dicho governador Francisco Piçarro, su hermano, el dicho majuelo, porque hera suya la deuda sobre que hera este pleito y otorgó de no yr contra ella, so obligación de su persona y bienes.

Después de lo qual ant'el dicho teniente de corregidor paresció la parte del dicho governador Francisco Piçarro e presentó cierto memorial de costas, de las que avía fecho en el dicho pleito y causa, e vistos por el dicho licenciado Monleón, teniente de corregidor susodicho, las tasó en .iim. e ciento y ochenta e nueve mrs., con más un real de la sentencia y .viii. más al escrivano.

Después de lo qual, en treze días del dicho mes de jullio, año susodicho, ant'el dicho teniente paresció el dicho Francisco Sánchez, en nonbre del dicho Pero de Barrantes, y dixo que, no se apartando de las dichas sus apelaciones, que por su parte estavan ynterpuestas, y sin perjuyzio de su derecho, e por redemir los bienes rematados y por escusar la bexación e molestia que se avía fecho a su parte y al fiador de saneamyento, so las dichas protestaciones exybió ant'el dicho juez el principal y costas y lo quería pagar syn perjuyzio de lo susodicho, y exybió ant'el escrivano de la causa y testigos setecientos y .xxxii. ducados en oro e myll e cien reales, e más otros noventa y siete mrs.

Y en el dicho día treze del dicho mes de jullio y año susodicho, ante el dicho escrivano e testigos paresce que la dicha Ynés Rodrigues de Aguilar, en nonbre del dicho governador Francisco Piçarro, su hermano, e por virtud del poder que d'él tenya, dixo que se dava y dio por contenta y pagada de todas las dichas trezientas y honze myll y novecientos e noventa y siete mrs. del principal, la qual dixo que los recibía y recibió realmente y con efeto, de mano de Graviel de Bega, alguasil mayor de la dicha cibdad de Trugillo, e asy mysmo dixo que se dava y dio por contenta y pagada de otros dos myll y dozientos e veynte y tres mrs. de las costas, y lo firmó de su nonbre, syendo testigos Francisco González y Alonso Durán y Bicente Enríquez y García del Amarilla.

E asy mysmo paresce que en el dicho día ant'el dicho escrivano y juez susodicho paresció el dicho Francisco Sánchez, en nonbre del dicho Pero Barrantes, y dixo que debaxo de las protestaciones por él fechas, hesibía la décima de la dicha execución en quatrozientos y setenta y quatro reales y medio y .xiiii. mrs. y en quatro pieças de diez ducados cada una, e paresce qu'el dicho Graviel de Bega, alguasil mayor de la dicha cibdad, recibió la dicha quantía, que todo montó .xxximcc. mrs., y se dio por contento y entregado y pagado de la dicha décima del dicho Francisco Sánchez, en nonbre del dicho Pero de Barrantes, y más dos reales para su persona por un día que avía ydo a prender a el fiador, como más largamente consta y paresce por los autos del dicho pleito.

E asy mysmo paresce que pasaron otros autos entre las dichas partes, cerca de las escripturas e certificación sobre que hera el pleito.

Después de lo qual, en la dicha cibdad de Granada, ante los dichos nuestro presidente y oydores el procurador del dicho Pero Barrantes se presentó en grado de apelación con el proceso del dicho pleito e una petición, en que dixo que, visto el dicho proceso, se hallaría que la sentencia definitiva en él dada e pronunciada por la justicia de la dicha cibdad de Trugillo e todo lo demás por ella fecho y autuado hera nynguno y [digno] de rebocar, por lo syguiente:

[1] Lo primero por no ser dada a pedimyento de parte, el proceso no estava en tal estado, no se avía guardado la forma y orden de derecho necesaria, por lo qual todo hera ninguno e por tal se avía de declarar.

[2] Lo otro, porque en caso que lo susodicho cesara, no se podía executar la dicha sentencia y executoria syn que por parte del dicho governador se cumpliera, que hera que diera a su parte primeramente el previllegio del juro en la dicha cantidad en que así su parte avía sydo condeando, con lo que dello oviese cobrado, porque no hera justo que su parte le oviese de pagar los dineros y cobrase el juro y no dar orden cómo su parte toviese título a lo que ansí le benía y avía de aver de los dichos mrs. que ansí avía pagado en dineros con lo corrido dellos.

Por todo lo qual nos pidió y suplicó mandásemos rebocar y dar por nynguno todo lo fecho por el dicho juez, mandando que a su parte le fuesen bueltos sus dineros que ansy avía pagado, syn costa, y, si la parte contraria quería cobrar alguna cosa de su parte, avía de ser dándole ante todas cosas el previllegio e título del dicho juro en la dicha cantidad, con lo que dello oviese corrido y cobrado, y en caso qu'esto no oviese [lugar], mandásemos que dentro de un breve término fuese obligado a lo complir, pues estava pagado de su deuda, y pidió serle fecho cumplimiento de justicia y costas.

De la qual dicha petición por los dichos nuestro presidente y oydores fue mandado dar treslado a la otra parte para que contra ello respondiese para la primera audiencia lo que viese que le conbenya, 
cerca de lo qual fue el dicho pleito concluso y bisto por los dichos mi presidente y oydores, probeyeron un auto, por el qual en efecto mandaron qu'el dicho Pero Barrantes sustanciase este pleito como biese que le convenya.

Después de lo qual el dicho Alonso Moyano, en nonbre del dicho Pero Barrantes, por su petición que presentó nos hizo relación diziendo que se le avía mandado sustanciar este pleito y porqu'el dicho Francisco Piçarro hera muerto, por ende que nos suplicava le mandásemos dar nuestra carta de enplazamiento contra los herederos del dicho Francisco Piçarro, que heran Hernando Piçarro e Ynés Rodrigues, sus hermanos, con quien siguiese este pleito. Y por los dichos nuestro presidente y oydores fue probeydo así y se le dio carta de emplazamiento en forma contra los de suso nonbrados, haziéndoles saber el dicho pleito y estado d'él, y que dentro de cierto término en ella contenido binyesen en seguymyento del dicho pleito y apelación, como a herederos y hermanos del dicho Francisco Piçarro, y a desir y alegar de su derecho, concluyr y cerrar razones y a estar y ser presentes a todos los autos del dicho pleito hasta la sentencia definitiva, ynclusibe, y tasación de costas, sy las obiese, so ciertos apercibimyentos, como más largamente en la dicha nuestra carta de emplazamiento se contenía.

La qual paresce que fue notificada a la dicha Ynés Rodríguez de Aguilar y Francisco Rodrigues, vezinos del lugar de la Çarça, juridición de la cibdad de Trugillo, en sus personas, y paresce que en la villa de Medina del Campo, en el castillo y fortaleza que dize de la Motta, donde el dicho Fernando Piçarro estava preso por nuestro mandado, fue allá Juan de la Rúa, escrivano público de la dicha villa, para notificar al dicho Fernando Piçarro la dicha nuestra carta e provisión real, e preguntó por el susodicho a Alonso Ruyz, tío del dicho alcaide de la dicha fortaleza, e a Juan de Cáceres, su criado, los quales le respondieron que no le podían ver ny hablar syn licencia y cédula nuestra. E, visto lo susodicho, notificó la dicha provisión a los susodichos para que lo hiziesen saber al dicho Fernando Piçarro y fuese en seguimyento del pleito y causa que en ella se hazía mynción, y les hizo los apercibimyentos en ella contenidos y les dexó una memoria de lo que se contenya [en] la dicha provisión, según que así se contiene por los autos que sobrello pasaron.

E porque nynguno de los susodichos vino ny enbió en seguimyento del dicho pleito y causa en el término que les fue asygnado ny procurador por ellos, la parte del dicho Pero Barrantes les acusó la rebeldía en tienpo y forma y su procurador, en su nonbre, se afirmó con los dichos Hernando Piçarro y sus hermanas en todo lo por su partes dicho y alegado. Sobre lo qual el dicho pleito fue concluso e, visto por los dichos nuestro presidente y oydores, dieron e pronunciaron en él sentencia difinitiva, su tenor de la qual es este que se sigue:

«En el pleito qu'es entre Hernando Piçarro e Ynés Rodríguez de Aguilar, vezinos de la cibdad de Trugillo, e Francisca Rodríguez, hermanos del gobernador Francisco Piçarro, en su absencia e rebeldía, de la una parte, y Pedro de Barrantes, vezino e regidor de la dicha cibdad, e Alonso Moyano, su procurador en su nonbre, de la otra: Fallamos qu'el licenciado Alonso de Monleón, tenyente de corregidor de la cibdad de Trugillo, e Pedro de Monleón, su aconpañado, que deste pleito conozieron en la sentencia de tranze e remate que en él dieron e pronunziaron, de que por parte del dicho Pero Barrantes fue apelado, juzgaron e pronunciaron bien, por ende, que debemos de confirmar e confirmamos su juizio e sentencia del dicho juez e aconpañado, la qual mandamos se guarde e cunpla y exsecute como en ella se contiene y por causas que nos mueben no hazemos condenación de costas contra ninguna de las partes. Y por esta nuestra sentencia difinytiba juzgando así lo pronunciamos e mandamos.

El licenciado Tello Girón. Dotor Miguel de Ribera. Dotor Peñaranda. El licenciado Pedrosa».

La qual dieron e pronunciaron en la dicha cibdad de Granada, estando haziendo audiencia pública, en diez días del mes de dizienbre del año que pasó de myll y quinyentos y quarenta y siete años, estando presente el procurador del dicho Pero Barrantes y en rebeldía de las otras partes.

De la qual dicha sentencia el procurador del dicho Pero Barrantes se presentó por su petición de apelación que ante los dichos nuestro presidente y oydores e, hablando con el acatamiento devido, dixo que la dicha sentencia hera nynguna y se avía de rebocar por lo syguiente:

[1] Por lo general e porque la execución y sentencia de revista y todo lo demás fecho e procedido y executado por la justicia de la dicha cibdad de Trugillo avía sido nynguno e por tal se abía de 
pronunciar y declarar, mandando bolver e restituyr a su parte todos sus bienes libremente y sin costa alguna, por lo que resultava del proceso y porque ante el dicho juez no se avía presentado escriptura que truxese aparejada execución, la carta executoria no la traya, hera condicional, su parte hera obligado a dar y pagar a la parte contraria .cccm. e tantos mrs., dándole certificación para cobrar el juro que dellas montase de nos o el previllegio del juro con lo corrido, porque su parte oviese y cobrase para sí, esto avía de preceder de parte de las partes contrarias, primero que oviese lugar la execución contra su parte, y en esto nynguna duda se podía poner, especialmente, ofreciendo y deposytando su parte, como avía deposytado, los dichos mrs.

[2] Lo otro, porque no se avía podido mover el dicho juez ny nuestros oydores por la respuesta de la dicha Ynés Rodrigues, diziendo que su parte tenya en su poder la dicha certificación y la avía cobrado en su nonbre Rodrigo de Hermosylla, porque, demás de no ser ansy como la dicha Ynés Rodrigues dezía, se hallaría que la demanda del procurador viejo que se avía puesto a su parte avía sydo por hebrero del año de .xxxvi. y la carta de pago que avía dado Hermosylla, en que avía recibido la dicha certificación, avía sydo durante el dicho proceso, por agosto de .xxxvii. años y la sentencia de revista que en el dicho pleito se avía dado avía sydo por abril del año de .dxxxviii., por manera que después de la dicha sentencia no paresce que su parte oviese recibido la dicha certificación, y, aunque la obiera recibido antes, no bastava executorya.

[3] Lo otro, porque el entendymiento verdadero y lo que las dichas sentencias y carta executorya quieren y nos mandaba hera que así por este se diese realmente el juro que montaba los dichos trezientos y onze myll y ciertos mrs. para que lo aya para sí, y avyendo las partes contraryas sacado privylegyo del dicho juro de nos de lo que montaban los dichos mrs., y no cunplyan con dar la dicha certificación y le hera obligado le dar el dicho previllegio, con lo que oviese corrido del dicho juro, y en esto nynguna dubda avía, conforme a las dichas sentencais, porque la certificación hera de nyngún efeto, estando executado y sacado previllegio de nos. Y porque en realidad de verdad las partes contrarias por virtud de la dicha certificación avían sacado previllegio del dicho juro y de lo que montaron las dichas .ccc. y .xim. e tantos mrs. que a su parte se le mandaban pagar y lo tenya en su poder, y por virtud d'él sus procuradores avían cobrado el dicho juro desd'el año pasado de .dxlii., donde claramente parescía no aver cumplido con su parte, conforme a las dichas sentencias.

[4] Lo otro, porque, aunque fuese verdad que las partes contrarias sacasen el dicho previllegio después que pendiere este pleito, pues la fecha d'él sonaba el año pasado de .imdxlii. años, todavía la dicha executoria se avía de dar por nynguna, pues hera pública clara que tenía en su poder la dicha certificación y no la avía dado a su parte, pues syn ella no se le diera el dicho previllegio, y así parescía a nos, pues en el mysmo benya ynserta la dicha certificación, y así las partes contrarias no se podían escusar de dar y entregar al dicho su parte el dicho previllegio con lo corrido y, hasta tanto qu'esto se hiziese, no se podía tener dubda, sino que la dicha execución no avía avido lugar y se avía de dar por nynguna y bolver a su parte sus bienes libremente, e porque no obstava desir que la debda hera de Juan Piçarro e no de Francisco Piçarro, porque, syendo asy, la executoria e todo lo por virtud della fecho avía sydo todo nynguno, e su parte condenada a pagar a quien no devía y no executado a pedimiento de su acreedor, e por esta mysma razón la dicha execución hera ninguna y se la avía de mandar bolver sus bienes, pero se hallaría qu'esta ecepción avía sydo puesta en el pleito viejo y se avía averiguado e provado que, no enbargante que la dicha obligación sonaba a Hernán Piçarro, los bienes avían sydo de Franciaco Piçarro, e así por esto como porque las palabras de la dicha obligación dezían que se diesen los dichos mrs. en España a la persona que diese la dicha obligación, tenya fuerça de pedir en causa propia, y así se avían dado las dichas sentencias de vista e revista y executoria dellas contra su parte y en favor del dicho Francisco Piçarro, a quien se avía mandado pagar los dichos mrs.

[5] Lo otro, porque, no enbargante qu'el previllegio del dicho juro respeto de los dichos mrs. que a su parte se pidían se avía ganado e dado por nos a pedimyento de Gonçalo Piçarro, hermano del dicho Hernando Piçarro, e Ynés Rodríguez, como herederos del dicho Juan Piçarro, avía sydo a fin de defraudar a su parte y, en realidad, de verdad del dicho juro pertenecía al dicho Francisco Piçarro e a los dichos Fernando Piçarro e Ynés Rodrigues, sus hermanos, como sus herederos, y ansí tenydo en su poder el dicho previllegio y con poder suyo cobraban el dicho juro sus mayordomos e procuradores.

[6] Lo otro, porque de una manera e de otra, pues las partes contrarias querían cobrar de su parte y lo avían cobrado realmente, heran obligados a dar el dicho juro con lo corrido o bolver a su parte 
sus dineros libremente, porque, de otra manera, el agravio y daño que a su parte se le hazía hera notorio y a ello nos no devíamos de dar lugar.

[7] Lo otro, porque ser los dichos Hernando Piçarro e Ynés Rodrigues herederos universales del dicho Francisco Piçarro nynguna dubda avía y como tales se avía entregado en sus bienes y los tenyan e poseyan.

[8] Lo otro, por todo lo demás que por su parte estava dicho y alegado en esta causa, que avía aquí por repetido, y si hera necesario lo dezía y alegava de nuevo, por ende, que nos pedía y suplicava mandásemos rebocar la dicha sentencia, haziendo en todo según y como por su parte estava pedido y de suso contiene.

Otrosy, hizo representación del proceso viejo que contra su parte se avía traydo, a pedimyento del dicho Francisco Piçarro, sobre las dichas trezientas y honze myll y tantos mrs.

De la qual dicha petición por los dichos nuestro presidente y oydores fue mandado dar traslado a las otras partes y el dicho pleito fue concluso, porque contra ello no dixeron ny alegaron cosa alguna, y la parte del dicho Pero Barrantes nos suplicó le mandásemos dar nuestra carta de emplazamiento contra las dichas partes. E paresce que por los dichos nuestro presidente y oydores se mandó dar y dio nuestra carta de emplazamiento en forma contra el dicho Hernando Piçarro e Ynés Rodríguez de Aguilar y Francisca Rodríguez, ynserta en ella la difinitiva en este pleito por los dichos nuestro presidente y oydores dada, para que, dentro de cierto térmyno en ella contenydo, biniese o enbiasen en seguimyento del dicho pleito y causa, so ciertos apercibimyentos, como más largamente se contiene en la dicha nuestra carta de emplazamiento.

La qual paresce que se notificó a la dicha Francisca Rodríguez, hermana del dicho Francisco Piçarro, en el lugar de la Çarça, y a la dicha Ynés Rodrigues de Aguilar en la dicha cibdad de Trugillo, en sus personas, e paresce que en la villa de Medina del Campo, en la fortaleza y castillo que dizen de la Motta, Gerónimo d'Espinosa escrivano, de pedimyento de la parte del dicho Pero Barrantes, fue notificada al dicho Fernando Piçarro la dicha nuestra carta de emplazamiento y preguntó por ella Fernán Ruyz Baca, alcayde della, el qual respondió que no lo podía aver, y el dicho escrivano la notificó ante las puertas de la dicha fortaleza y le hizo saber al dicho alcayde lo que en ella se contenya y se la leyó de berbo a berbun, para que se lo dixese y hiziese saber al dicho Fernando Piçarro. E paresce que le hizo esta notificación dos bezes, según qu'el dicho escrivano así lo da por fee e testimonio.

E porque en el término contenido en la dicha nuestra carta de emplazamiento nynguno de los susodichos no vino ni paresció procurador por ellos en la dicha nuestra audiencia, la parte del dicho Pero Barrantes les acusó la rebeldía en tienpo y en forma devida de derecho, y se afirmó con ellos en lo que por su parte en el dicho pleito estava dicho.

Después de lo qual, en .xxix. días del mes de henero del año que pasó de myll e quinyentos y quarenta e nueve años, el procurador del dicho Pedro Barrantes nos hizo relación por su petición, que presentó ante los dichos nuestro presidente y oydores, diziendo que Gonçalo Piçarro, hermano del dicho Fernando Piçarro, y sus consortes, hera fallescido desta presente vida e que por su fallescimiento avía subcedido en los bienes y herencia de Juan Piçarro, su hermano y del dicho Gonçalo Piçarro, el dicho Fernando Piçarro, su hermano, qu'estava preso en la Motta de Medina, e porqu'el dicho pleito se tratava del perjuyzio del dicho Hernando Piçarro, como heredero de los susodichos, por ende, que nos suplicava le mandásemos dar nuestra carta de emplazamiento para el dicho Fernando Piçarro, porque viniese y asistiese en el dicho pleito y le parase perjuyzio lo que en él se hiziese. E por los dichos nuestro presidente y oydores fue probeydo así y le man[daron] dar y se le dio nuestra carta de emplazamiento en forma, haziéndole saber lo susodicho y el dicho pleito y estado d'él, para que binyese o enbiase en seguimyento d'él, sy quisiese [dezir] y alegar de su derecho e concluyr e cerrar razones, so ciertos apercibimyentos, según que más largamente se contiene en la dicha nuestra carta de emplazamiento.

Y paresce que en la dicha villa de Medina del Campo, en doze días del mes de mayo del dicho año de myll e quinyentos y quarenta e nueve años, Juan Losa, nuestro escrivano, de pedimyento de la parte del dicho Pero Barrantes, fue al castillo e fortaleza que dizen de la Motta para notificarla al dicho Fernando Piçarro, preso qu'estava dentro della, e porque no pudo ser avido para se la notificar en persona, la notificó a Alonso Nieto Baca, alcaide della, y le hizo saber el pleito e causa en ella contenido para que lo dixese e le hiziese saber al dicho Fernando Piçarro, para que enbiase en se- 
guimyento del dicho negocio en el término en la dicha provisión contenydo, y le hizo los apercibimyentos en ella contenidos, según que más largamente por el testimonyo e fee de lo susodicho consta.

De que ante los dichos nuestro presidente y oydores e, porque en el dicho término ny después d'él el dicho Fernando Piçarro no vino ni paresció procurador por él en la dicha nuestra audiencia, la parte del dicho Pero Barrantes le acusó la rebeldía en tienpo y en forma devida de derecho. Y la parte del dicho Pero Barrantes se afirmó con el dicho Fernando Piçarro, como heredero del dicho Gonçalo Piçarro, y sus consortes, en todo lo por su parte dicho y alegado en este dicho pleito y causa y, si hera necesario, lo dezía y alegava de nuevo, e nos suplicó mandásemos haser en todo según y como por su parte estava pedido y alegado. De lo qual se mandó dar traslado a las otras partes, para que contra ello dixesen y alegasen lo que conviniese a su derecho para la primera audiencia. Y la parte del dicho Pero Barrantes les acusó la rebeldía, porque contra ello no respondieron ny alegaron cosa alguna.

Y el dicho pleito fue concluso e visto por los dichos nuestro presidente y oydores, rescibieron a las dichas partes a prueva en cierta forma y con cierto plazo e término, dentro del qual paresce que por parte del dicho Pero Barrantes fue fecha cierta probança e presentada ante los dichos nuestro presidente y oydores, e así mysmo ciertas pusiciones que declaró el dicho Fernando Piçarro, y fue pedida y fecha publicación y dado copia e traslado a las dichas partes [contrarias], y dicho de bien probado, y concluso el dicho pleito e, visto por los dichos nuestro presidente y oydores, dieron e pronunciaron en él sentencia difinitiva en grado de revista, su tenor de la qual es este que se sigue:

«En el pleito qu'es entre Pero de Barrantes, vezino de la ciudad de Trugillo, y Alonso Moyano, su procurador en su nonbre, de la una parte, y Fernando Piçarro e Ynés Rodríguez de Aguilar, vezinos de la dicha ciudad, en su ausencia e rebeldía, de la otra: Fallamos que la sentencia difinytiba en este pleito dada e pronunciada por algunos de nos, los oydores de la Audiencia de SS.MM., de que por parte del dicho Pero de Barrantes fue suplicada, en quanto por ellas confirmamos la sentencia definitiva en este pleito dada e pronunciada por el licenciado Alonso de Monleón, teniente de corregidor de la dicha ciudad, y Pero de Monleón, su aconpañado, que del dicho pleito conozieron, en que mandaron hazer tranze e remate de bienes executados y pago a la parte de Francisco Piçarro de trecientas y honze myll e nobezientos y nobenta e siete mrs., fue y es buena, justa e derechamente dada e pronunciada, e por tal, sin enbargo de las razones a manera de agrabios contra ella dichas e alegadas en el dicho grado de suplicación, la debemos confirmar e confirmamos, en quanto a lo susodicho en grado de revista, pero en quanto el dicho juez por la dicha su sentencia, que por la nuestra confirmamos, condenó al dicho Pero de Barrantes en las costas de la execución de las dichas trezientas e honze myll y nobezientos y nobenta y siete mrs. y en las costas del dicho pleito, rebocamos las dichas sentencias en quanto a las dichas costas y mandamos que le sean bueltos, tornados e restituydos al dicho Pedro Varrantes todos e qualesquyer bienes y mrs. que por razón de las dichas costas le obieren llevado, y mandamos que los dichos Fernando Piçarro e Ynés Rodríguez de Aguilar den y entreguen al dicho Pero de Barrantes, dentro de treynta días primeros siguyentes, el prebillegio del juro o la certificación que para ello se le dio en la Casa de la Contratación de la ciudad de Sevilla, que por esta razón y al respeto de las dichas trezientas e honze myll e nobecientos e nobenta e siete mrs. recibió e tiene S.M., con más los corridos del dicho juro después qu'el dicho Pedro de Barrantes pagó las dichas trezientas e honze mill y nobecientos e nobenta e siete mrs., con lo que corrieren hasta que realmente se lo ayan entregado, e que, si dentro de los dichos treynta días los dichos Hernando Piçarro e Ynés Rodrigues de Aguilar no dieren y entregaren al dicho Pero Barrantes el dicho juro con lo corrido d'él o la dicha certificación, los dichos Hernando Piçarro e Ynés Rodrigues de Aguilar buelvan e restituyan al dicho Pero Barrantes las dichas .cccximdccccxcvii. mrs. con todas las costas e yntereses de la cobrança dellas. E por causas que nos mueben no hazemos condenación de costas contra nynguna de las dichas partes. E por esta nuestra sentencia en grado de rebista juzgando así lo pronunciamos e mandamos.

El licenciado Bezerra. El licenciado Tello Girón. El licenciado Arze de Otalora». ${ }^{99}$

${ }^{99}$ Previamente hay tachada otra sentencia, similar a la de vista. 
La qual dieron e pronunciaron en la dicha cibdad de Granada, estando haziendo audiencia pública, en veynte e tres días del mes de agosto de myll e quinyentos y cinquenta y dos años, estando presente el dicho Alonso Moyano, como procurador del dicho Pero Barrantes y en rebeldía de los demás.

E agora por parte del dicho Pero Barrantes nos hizo relación por su petición, diziendo que en este dicho pleito se avían dado e pronunciado sentencias difinitivas por los dichos nuestro presidente y oydores en vista y grado de revista, por ende, que nos suplicava que le mandásemos dar nuestra carta executoria para que le fuesen guardadas, cumplidas y executadas e que sobrello probeyésemos como la nuestra merced fuese. Lo qual, visto por los dichos nuestro presidente y oydores, fue acordado que devíamos mandar dar esta nuestra carta executoria para vos, los dichos nuestros juezes e justicias, en la dicha razón. E nos tovímoslo por bien, porque bos mandamos a todos e a cada uno de vos en los dichos vuestros lugares e jurisdiciones, según dicho es, que luego como con ella o con el dicho su traslado signado fuéredes requerido o requeridos por parte del dicho Pero Barrantes, beades las sentencias difinitivas en este pleito dadas, asy por la justicia de la dicha cibdad de Trugillo como por los dichos nuestro presidente y oydores en vista y grado de revista, que de suso ban encorporadas, y atento el tenor y forma de la última sentencia de revista, las guardéys y cumpláys y executéys en todo e por todo, según y como e por la forma e manera que en la dicha última sentencia de revista se contiene. E contra el tenor e forma della no bays ni paséys ny consyntáys yr ny pasar, agora ny en nyngún tienpo, ny por alguna manera, so pena de la nuestra merced e de .xm. mrs. para la nuestra cámara, so la qual dicha pena mandamos a qualquier escrivano público, etc. [sic].

Dada en Granada, a [blanco] días del mes de [blanco] de myll e quinyentos e cinquenta e dos años. El licenciado Bezerra. El licenciado Tello Girón. El licenciado Arze de Otalora. Van tasados veynte y un reales en este otro pliego junto a éste, a rayas que se puso una sentencia por yerro, la qual está un pliego más atrás.

Va escripto este registro en diez pliegos con éste. 


\section{APÉNDICE II}

[1542/04/01. Valladolid]

Mari Sánchez se querella de su marido, Cristóbal Martín, por intento de asesinato.

AHN, OO.MM., AHT, expte. 78.304.

\section{Muy poderoso señor}

Mari Sánchez, muger de Christóval Martín, vezinos del lugar de La Çarça, término de la villa de Montanches, presa en la cárcel pública della, paresco ante V.A. por mi procurador y me querello criminalmente del dicho Christóval Martín, mi marido, y de los que demás parescieren enculpados en los delitos que de yuso se hará minción y de los alcaldes hordinarios de la dicha villa, y contando el caso digo que, reynando V.A. en estos Reynos y premisas las otras solenidades de derecho requeridas, podría aver doze años, poco más o menos, que, estando yo y el dicho mi marido en uno en el dicho lugar, haziendo vida maridable, el susodicho cometió cierto delicto de adulterio con yncesto, en que tuvo acesso carnalmente con Mari Sánchez, muger de Savastián Martín çapatero, hermano del dicho Christóval Martín, ya difunto, y por ello se fue huyendo de la justicia y se fue a las Yndias del Perú, adonde estuvo doze años, poco más o menos, y es así que podrá aver seys meses, poco más o menos, que el dicho mi marido vino de las dichas Yndias y truxo y tiene treynta mill ducados de oro e más, e, siendo como yo y el susodicho somos de linaje de labradores y gente comund, viéndose el susodicho rico y favorescido por se casar con alguna donzella de linaje e hija de algo, como al presente se dizen, y tiene por muy cierto que está casado e desposado con una hija de un cavallero de Trujillo, lo qual está secreto entre ellos hasta tanto que el dicho mi marido me matase, y por me defraudar a mí de la parte que me pertenesce de los dichos treynta mill ducados, el dicho mi marido determinó y puso por obra de me matar en esta manera: que teniendo el susodicho confiança de la justicia ordinaria de la dicha villa, por aver prestado al uno de los alcaldes della trezientos ducados y más, que se haría todo lo que él quisiese, me acusó ante los dichos alcaldes de la dicha villa de adulterio y para ello ynduxo, sobornó y dadivó ciertos testigos para que depusiesen que yo avía cometido adulterio con cierta persona contra el dicho mi marido, estando absente, para que a lo menos, siendo yo condenada a tormento por los yndicios, tuviese forma por donde me matar en el dicho tormento por quedar libre, y es así que por los dichos testigos dadivados los dichos alcaldes me condenaron a tormento y para efectuar el dicho mi marido su mal propósito que tenía de me matar en el dicho tormento, el qual me avía de ser dado de agua y cordeles e garrotes, en un día e días de este presente mes de março deste año de mill y quinientos y quarenta y dos años el dicho mi marido, con poco temor de Dios y de la justicia de V.A., supo y procuró de los dichos alcaldes el día que me avía de ser dado el dicho tormento e ynduzió e provocó, dando y prometiendo dineros a Francisco Gómez, peón de verdugo de la dicha villa, el qual me avía de dar el dicho tormento, me matase con tormentos, lo qual el dicho verdugo començó a poner por obra, cortándome las piernas y braços con los dichos cordeles y dándome otros golpes y malos tratamientos, e me matara, si no fuera porque en el dicho tormento fue avisada cómo el dicho verdugo avía rescebido los dichos dineros del dicho mi marido por que me matase, y así le recusé y fue puesto otro verdugo en su lugar, que me acabó de dar el dicho tormento, y así mismo el dicho mi marido puso a un negro, que dizen Gonçalo, en la dicha cárcel y él dio e mandó dar ciertos polvos de solimán y rejalgar mortíferos y veninosos para que el dicho negro los echase en el agua que se me avía de dar en el dicho tormento, y por ello el dicho mi marido prometió al dicho Gonçalo trezientos ducados y le dio partes dellos, y los dichos polvos fueron hallados en poder del dicho negro, los quales fueron tomados y puestos por la justicia en poder de una buena persona, e me matara el dicho mi marido con los dichos polvos si no fuera por Dios, nuestro Señor, que lo quiso descubrir.

Y así mismo el dicho mi marido dixo en la plaça pública de la dicha villa en un día del dicho mes que jurava a Dios que, si no se hazía justicia de mí, que me avía de matar, que treynta mill ducados tenía para se librar, segund todo constará a V.A. por esta ynformación de que hago presentación.

E sobre los dichos delictos los dichos alcaldes de la dicha villa prendieron al dicho mi marido e, deviéndole tener preso y a buen recabdo, pues los dichos delictos tienen pena de muerte natural y confiscados la mitad de sus bienes para la cámara de V.A., los dichos alcaldes, mostrándose muy amigos y familiares y favorables al dicho mi marido, por razón de los dichos dineros que les tiene 
prestados y por razón que muchos cavalleros de las cibdades comarcanas a la dicha villa, los quales favorescían al dicho mi marido por razón de los dichos dineros que a todos tiene prestados el dicho mi marido, los dichos alcaldes lo tienen puesto en una casa suelto y sin prisiones, como si no oviese cometido delicto, y los dichos cavalleros enbían muchas cartas a la dicha villa, así a la justicia como a otras personas, para que favorescan al dicho Christóval Martín, como a mi letrado y procurador amenazándolos que los han de matar por que me favorecen, por manera que por ninguna vía pienso alcançar justicia ante los alcaldes de la dicha villa.

E, demás desto, teniéndome los dichos alcaldes ya suelta y sin prisiones, después que me fue dado el dicho tormento, porque les pedí y requerí me diesen la dicha ynformación para me quexar del dicho mi marido e de los demás delinquentes ante V.A., me echaron luego en prisiones, echándome a los pies una cadena muy gruesa, y me molestan por formas y maneras yndividas al efecto que yo pida mi justicia ante ellos y no me vaya a quexar a V.A.

Y, así mismo, por torcedero, sin aver cabsa ni razón ni culpa, el día que Juan Martín, mi procurador, avía de partir de la dicha villa para esta Corte los dichos alcaldes, por que yo no pidiese mi justicia ante V.A., tuvieron forma para que el dicho mi marido diese quexa del dicho Juan Martín, e dieron mandamiento para le prender y me prendiera si no fuera porque fue avisado, lo qual hizieron a efecto, porque, de todos mis parientes, solamente el dicho Juan Martín me osa de favorescer, y porque, prendiéndome, el dicho mi procurador no tenía quién osase de favorescerme ni pedir ante V.A. mi justicia.

E, demás desto, el dicho día que se avía de partir el dicho mi procurador para esta Corte los dichos alcaldes, de pedimiento del dicho Christóval Martín, por vía de torcedero hizieron cierta ynformación que V.A. verá, diziendo que yo avía dado dineros al dicho negro por que descubriese los dichos polvos que el dicho mi marido le avía dado para me matar.

E, demás desto, segund los dichos alcaldes me son contrarios e sospechosos y muy favorables al dicho mi marido, temo que, si los susodichos obiesen de sentenciar difynitivamente el dicho processo del adulterio que me acusa el dicho mi marido después de me ser dado tormento y purgados los yndicios, me temo y recelo que me agraviarían y buscarían maneras como me condenen.

E, así mismo, me temo que el dicho mi marido sabrá, siendo avisado por los dichos alcaldes, a qué letrado enbían el proceso a sentenciar y lo enbiarían al letrado que el dicho mi marido les dixere para que, por complazer al dicho mi marido e por dineros que le dé, me condene y dé la sentencia a su voluntad.

Y, así mismo me temo que por razon que el dicho Christóval Martín tiene en la cibdad de Mérida de los dichos cavalleros y de otras personas la dicha justicia de la dicha cibdad por el dicho favor, no me guardarán justicia, ni yo pienso ante ella alcançar justicia.

Pido y suplico a V.A., porque mi justicia no peresca, ansí en lo que el dicho mi marido me acusa del adulterio, como en lo que yo le acuso a él de los delictos que contra mí ha cometido V.A. provea un juez pesquesidor por servicio de Dios, nuestro Señor, con su alguazil y escrivano y con días y salarios conpetentes para que sentencie el proceso de la dicha cabsa de adulterio en que me acusa el dicho mi marido y proceda contra él y contra los más delinquentes en los dichos delictos que contra mí son e an sido cometidos e sobre lo [a] ello anexo e dependiente, porque mi justicia no peresca, y para todo ello y en lo necesario el real oficio de V.A. ymploro y pido justicia y costas, y juro a Dios y esta cruz $(\dagger)$ que esta querella no la doy maliciosamente, salbo por que me sea hecha justicia, y me profiero a dar fianças legas, llanas y abonadas para salarios y costas de juez y alguazil y escrivano y que lo contenido en esta mi querella será cierta y verdadera.

El doctor Juan Gil. 